\title{
STRUCTURALLY CONTROLLED HYDROTHERMAL DOLOMITE, EGANVILLE-DOUGLAS PALEOZOIC OUTLIER, OTTAWA-BONNECHERE GRABEN, EASTERN ONTARIO
}

\author{
by
}

\section{ULAN NURKHANULY}

A thesis submitted to the Faculty of Graduate and Postdoctoral Affairs in partial fulfillment of the requirements for the degree of

Master of Science

in

Earth Sciences

Carleton University

Ottawa, Ontario

(C) 2012, Ulan Nurkhanuly 


\section{ABSTRACT}

In Upper Ordovician (Trenton-equivalent) limestone of the Eganville-Douglas Paleozoic outlier, $\sim 50 \mathrm{~km}$ northwest of Ottawa, Ontario, sub-vertical bodies (up to 10s of metres in width) of replacement dolomite and vein dolomite are well exposed in a limestone quarry adjacent to the Bonnechère River. Additional minor dolomitization has been discovered at one other nearby locality. The region lies within the Ottawa Bonnechere graben, a cratonic-scale fault system originating in the Neoproterozoic.

Dolomitization shows a lateral gradation from $100 \%$ replacement (+ porosity) in cores to isolated crystals in a non-porous skeletal-peloidal grainstone along the margins of the dolomite zones. Saddle dolomite occurs as fracture and vein-fill dolomite that post-dates the replacement dolomite. A WNW-ESE basement fault controls the axis of the Bonnechère River immediately to the north of the quarry. Zones of dolomite, and associated dolomite veins originating as part of local strike-slip faults, display orientations that fit the expected extension and strike-slip components, respectively, of structural fabric associated with a regional wrench-style fault system. $\delta^{18} \mathrm{O}$ values for replacement dolomite (-12.71 to $-13.78 \%$ o) and saddle dolomite $(-12.2$ to $-12.73 \%$ o) are negative compared to the estimated value for Upper Ordovician shallow-water marine dolomite. Fluid inclusion data, in combination with oxygen isotope data, suggest that fluids responsible for dolomitization were hot $\left(87.2-115^{\circ} \mathrm{C}\right)$ brines of $\mathrm{Ca}-\mathrm{Mg}-\mathrm{Cl}$ origin. ${ }^{87} \mathrm{Sr} /{ }^{86} \mathrm{Sr}$ isotope ratios for replacement dolomite plot above the seawater curve for the Late Ordovician indicating that the fluids from which they precipitated had interacted with strata containing more radiogenic ${ }^{87} \mathrm{Sr}$. Potential sources are siliciclastics or Precambrian gneissic rocks, if they underlay the limestone in the outlier. The estimated 
temperature appears to be $10-20^{\circ} \mathrm{C}$ warmer than the expected burial temperature based on previous work evaluating conodont alteration indices. Such structurally-controlled hydrothermal alteration requires tectonism well within the North American craton, and it likely occurred during one of two periods of orogenic development along the Laurentian margin: (1) in the Late Ordovician, associated with Taconic orogenesis; and, (2) in the Late Devonian, associated with Acadian orogenesis. Both require more elevated geothermal gradients $\left(\sim 100^{\circ}\right.$ and $\sim 56^{\circ} \mathrm{C} / \mathrm{km}$, respectively) than previous studies have estimated assuming a stable craton-interior basin. As the region lay within the OttawaBonnechere Graben, this style of dolomitization likely highlights an unstable structural corridor, with elevated heat flow. The nature of dolomitization fits with more regionally distributed occurrences in adjacent basins (in Michigan, New York State), although the precise timing (Late Ordovician vs Late Devonian) remains uncertain. 


\section{ACKNOWLEDGEMENTS}

This research work was funded by a Natural Sciences and Engineering Council (NSERC) of Canada Discovery Grant awarded to my supervisor, Prof. George R. Dix. I would like to thank him for his patience, support, encouragement, and immense knowledge. His guidance helped me throughout the research and writing of this thesis.

I would also like to thank Mr. R.J. Selle (and son) for giving me access to the quarry and the opportunity to sample the rocks for this research. I also thank all the faculty, staff members (especially Mr. Peter Jones, and Ms. Lizzy Ann Spencer), and students of Earth Sciences Department, Carleton University.

Despite the geographical distance, my family was always nearby. I owe my deepest gratitude to my parents and my sister for their support, encouragement and for brightening my days with emails and phone calls from Kazakhstan.

This research work would not have been possible without the support of my friends from other departments at Carleton University, who gave me a much needed form of escape from my studies, and helped me focus enough to write my thesis.

Lastly, I offer my regards and blessings to all of those who supported me in any respect during the completion of my research work. 


\section{TABLE OF CONTENTS}

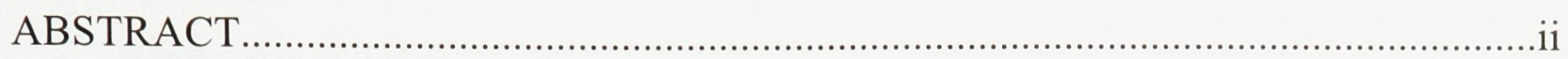

ACKNOWLEDGEMENTS ...............................................................................

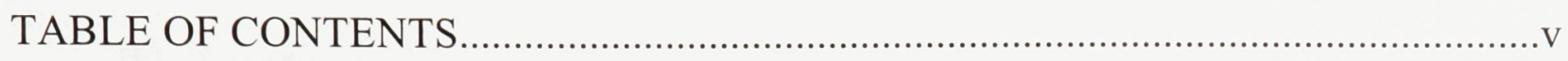

LIST OF FIGURES.......................................................................................

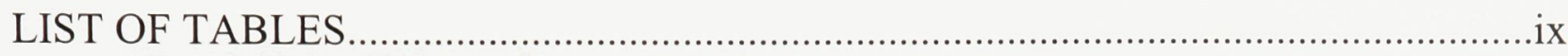

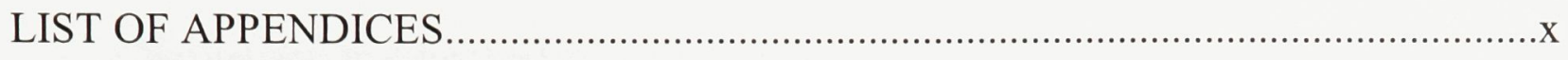

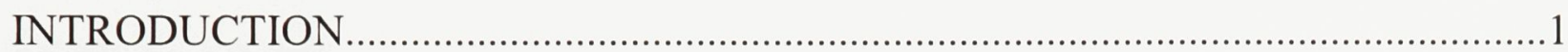

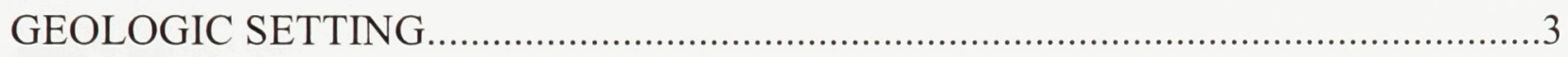

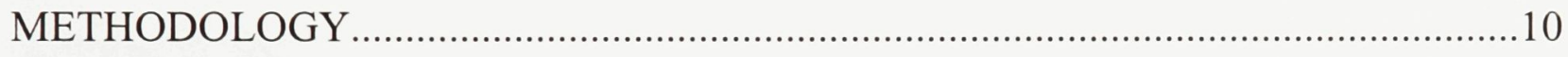

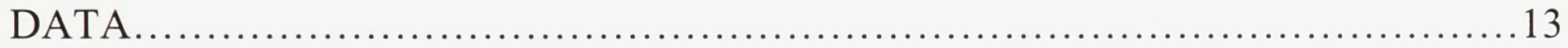

Geological framework ...............................................

Lithostratigraphy..............................................

Locality 1 (R.J. Selle quarry) .................................... 19

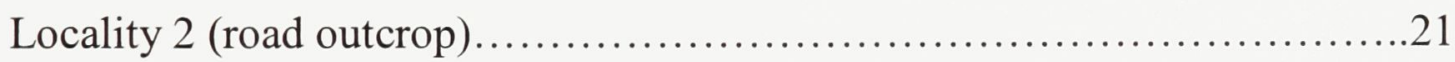

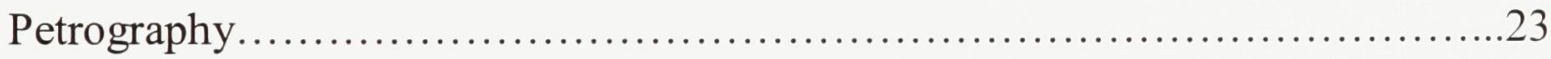

Limestone...................................................... 23

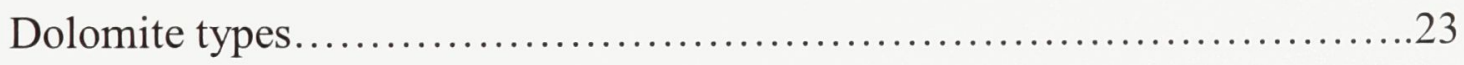

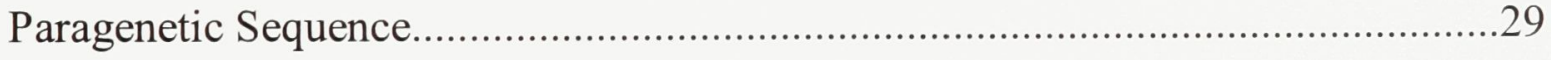

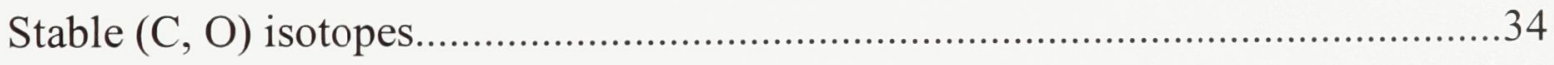

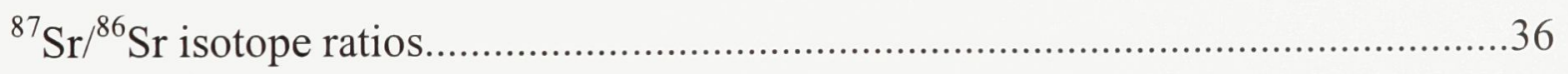

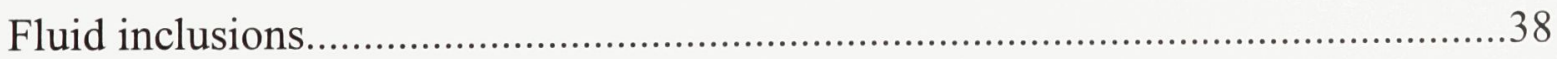

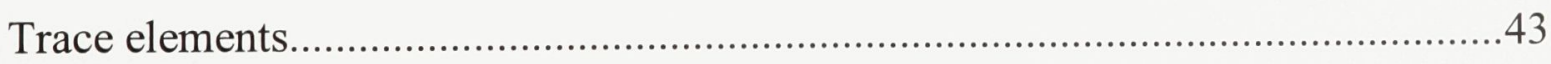

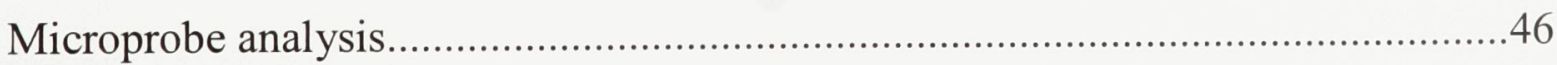

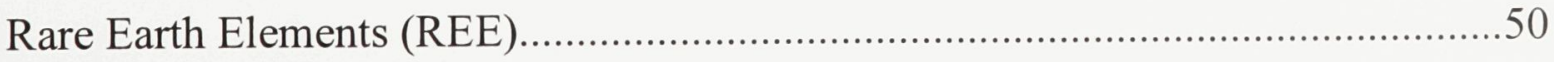


Structural style. 53

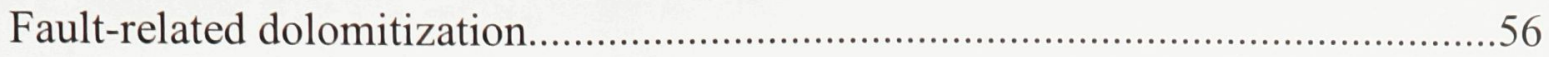

Hydrothermal Conditions versus Burial Heat................................................58

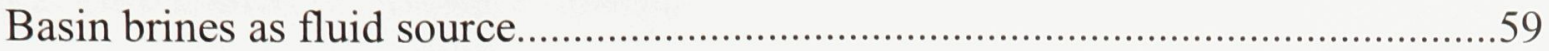

Geochemical evidence for hydrothermal alteration.....................................59

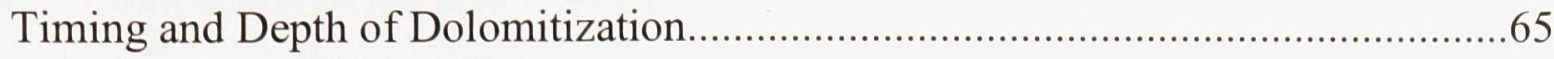

Comparison to other hydrothermal dolomite fields..........................................68

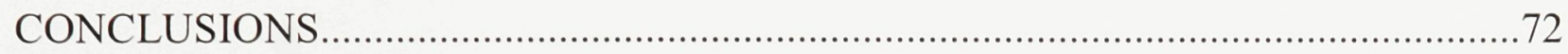

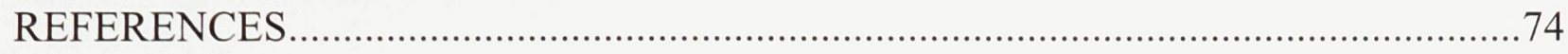

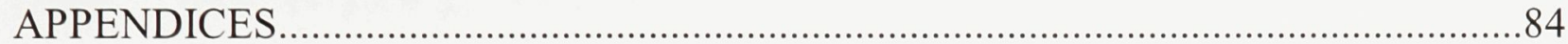




\section{LIST OF FIGURES}

Figure 1. Regional tectonic setting showing study area (red star) within the OttawaBonnechere Graben.

Figure 2. Distribution of Paleozoic structural outliers northwest of the Ottawa Embayment. 6

Figure 3. Comparison of the Lower to Upper Ordovician stratigraphic succession in the Ottawa Embayment, Mohawk Valley, central New York State, and eastern Michigan, within the Albion-Scipio petroleum field

Figure 4. Local bedrock geology and distribution of regional faults

Figure 5. Bedrock geology based on water well information 16

Figure 6. Geological map of Locality 1, shown at a scale of 1:1000, with current (2012) quarry wall limits

Figure 7. View of the northern wall of the quarry showing the trace of a strike-slip fault within a vertical body of dolostone 18

Figure 8. Lithostratigraphy of Locality 1 and photographs illustrating each unit (I-V)...20

Figure 9. Field attributes of dolomite exposed at Locality 2 .22

Figure 10. Stained thin-section images of host skeletal to peloidal grainstone from Locality 1 .26

Figure 11. Thin section photomicrographs of dolomite types from Locality 1 .27

Figure 12. Photomicrographs of dolomite from the Locality 2 .28

Figure 13. Stained thin section photomicrograph (A) and backscattered electron (B) images of stylolites cross-cutting dolomite crystals

Figure 14. View of the northern wall of the quarry showing abrupt lateral contacts between the host limestone and dolostone. 
Figure $15 . \delta^{13} \mathrm{C}$ and $\delta^{18} \mathrm{O}$ values for carbonate samples from Locality 1 and Locality 2

Figure 16. Photomicrographs of fluid inclusions.

Figure 17. Homogenization temperatures $\left(\mathrm{T}^{\circ} \mathrm{C}\right)$ and number of samples from fluid inclusion analysis

Figure 18. Trace-element composition of limestone and dolomites from Locality 1 and Locality 2 compared to the Upper Ordovician Trenton-Black River hydrothermal dolomite reservoirs data in New York.

Figure 19. $\mathrm{FeO}\left(\mathrm{wt}^{\mathrm{o}} \%\right.$ ) vs $\mathrm{MnO}(\mathrm{wt} \%)$ values of cores and rims for different types of dolomite.

Figure 20. Samples of Locality 1 and 2 limestone, dolostone and saddle dolomite normalized to Post-Archean Average Australian Shale.

Figure 21. Structures associated with left-lateral fault movement shown on strain ellipse (modified after Wilcox et al., 1973) and upward splaying (positive) flower structure.

Figure 22. Schematic fault-related hydrothermal dolomitization model for study area. 57

Figure 23. Fluid inclusion homogenization temperature $\left(\mathrm{T}^{\mathrm{O}} \mathrm{C}\right)$ vs. $\delta^{18} \mathrm{O}_{\text {diagenetic fluid }}$ for $\delta^{18} \mathrm{O}_{\text {dolomite }}$ values that were calculated from the equation $10^{3} \ln \alpha=3.2 \times 10^{2} \mathrm{~T}^{-2}-3.3$ (Land, 1983).

Figure $24 .{ }^{87} \mathrm{Sr} /{ }^{86} \mathrm{Sr}$ isotope values from Locality 1 and Locality 2 plotted in comparison to seawater ${ }^{87} \mathrm{Sr} /{ }^{86} \mathrm{Sr}$ isotope values from McArthur at el. (2001).

Figure 25. Location map of hydrothermal dolomite fields in eastern North America......71 


\section{LIST OF TABLES}

Table 1. Detailed description of dolomite types.

Table 2. Paragenetic sequence of the events as interpreted from petrographic studies from Localities 1 and 2 .

Table 3. Stable isotope and strontium results from Locality 1 and Locality 2 37

Table 4. Fluid inclusion results from Localities 1 and 2 40

Table 5. Trace elements results for the samples from Localities 1 and 2 . 44

Table 6. Microprobe results for different dolomite types. .47

Table 7. Microprobe results for calcite cement 48

Table 8. Rare Earth Elements for different samples from the study area. 51

Table 9. General attributes of hydrothermal dolomites in North America compared to this study .70 


\section{LIST OF APPENDICES}

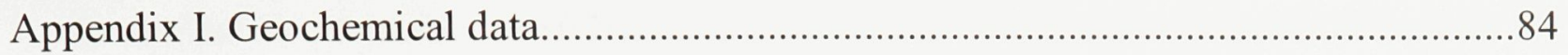




\section{INTRODUCTION}

In the last two decades, there has been much excitement connecting petroleum and mineral exploration potential in carbonate basins with hydrothermal dolomite (HTD). Hydrothermal diagenesis occurs when fluids are introduced to a given formation at a temperature that exceeds the ambient temperature of that formation (White, 1957; Machel and Lonee, 2002; Davies, 2004). It represents evidence for a geothermal anomaly and requires a mechanism or conduit for fluid movement. Faulting and/or fracturing form the common link (White, 1957; Davies and Smith, 2006). According to recent studies, hydrothermal systems may be of near-surface (or even synsedimentary) or of deep-burial origins (Davies and Smith, 2006), and, as such, the nature of dolomitization, its spatial extent, and related petroleum and mineral capacity depends on many factors, including porosity, permeability and composition of the host rock; pressure, temperature and composition of the hydrothermal fluid; the efficiency of the fluid recharge into the fault system; the effectiveness of the seal; and, the spacing and types of faults (Smith, 2006). Significant bodies of hydrothermal replacement dolomite are well known from sedimentary basins host to Upper Ordovician carbonate platform successions in North America (Davies and Smith, 2006).

In eastern Ontario, evidence of hydrothermal mineralization demonstrated by veins, local paleocavities, and as replacement of host limestone and dolostone has been long recognized to be associated with the Ottawa-Bonnechere Graben (Dix and Robinson, 2003), a prominent crustal fault zone in eastern North America (Figure 1). However, it was only in Summer 2009 that the first volumetrically significant vertical bodies of replacement dolostone that might be linked to HTD were discovered (Dix, unpublished 
data) resulting from geological mapping of Paleozoic outliers west of Arnprior. The dolostone is exposed in the R.J. Selle Quarry, $100 \mathrm{~km} \mathrm{NW}$ of Ottawa, near Eganville along the Bonnechère River, Ottawa Valley. Since 2009, the quarry expansion has provided even greater exposure of the dolomitic zones, thereby allowing a better understanding of their origin.

The purpose of my study is to present structural, petrographic, and geochemical (stable isotopes, trace elements, and fluid inclusions) evidence from the R.J.Selle quarry, and an adjacent road outcrop to demonstrate and evaluate the source of fluid, temperature of formation, and geologic history of dolomitization, and place this within a regional structural context. 


\section{GEOLOGIC SETTING}

The Ottawa Embayment is an intracratonic extension of the central St. Lawrence Platform (Sanford, 1993a). It encompasses eastern Ontario, northern New York State and southwestern Quebec, an area of $\sim 10000 \mathrm{~km}^{2}$. Its elongate shape partially demonstrates a Cambrian to Middle Ordovician sedimentary basin bordered by Precambrian highlands and opening out onto the regional epicontinental St. Lawrence Platform (Figure 1).

A Neoproterozoic to Ordovician sedimentary sequence is preserved within the Ottawa Embayment and structural outliers northwest of Arnprior (Figure 2). There are two stratigraphic sequences: the Sauk and lower Tippecanoe I (Sloss, 1963; 1988). The Sauk sequence consists of Neoproterozoic to Cambrian siliciclastics comprising the Potsdam Group overlain by Lower to Middle Ordovician platform interior carbonates and sandstones of the Beekmantown Group (Sanford and Arnott, 2010; Sanford, 1993). The lower Tippecanoe I sequence forms a second siliciclastic-to-carbonate platform succession of Middle to Late Ordovician age that records establishment of a forelandbasin carbonate platform, succeeded by basin-fill siliciclastics related to foundering of the platform (Sanford, 1993; Sharma et al. 2003).

There are four foreland platform successions (Figure 3), each describing a progressive west-directed regional onlap. The most regional of the four is the youngest, represented by the Ottawa Group, and is about 200 m thick (Uyeno, 1974; Sanford, 1993; Salad Hersi and Dix, 1997; Salad Hersi and Dix, 1999; Sharma et al., 2003). The Ottawa Group is Late Ordovician (Turininan through Edenian) in age. Compared to the better known historical stratigraphic divisions originating in New York, the Pamelia through 
Figure 1. Regional tectonic setting showing study area (red star) within the OttawaBonnechere Graben, modified from Bleeker et al. (2011). Paleozoic sedimentary rocks are indicated in shades of blue, forming the low elevation and low-relief St. Lawrence Platform, where this sedimentary cover is relatively undeformed (light blue), and the Appalachian Mountains, where these rocks are deformed (dark blue, beyond "Logan's Line" and the Appalachian structural front). Exposed Precambrian rocks are indicated in shades of pink. Major faults are indicated by black lines and down-thrown sides are shown with tick marks. Igneous intrusions are shown in shades of red and purple: dykes are shown as red lines. The Ottawa-Bonnechere Graben, including the Timiskaming Graben branch, is highlighted by a transparent overlay (light purple). The red square represents area of Figure 2. Map on the upper right corner indicates other hydrothermal dolomite fields in eastern North America. 


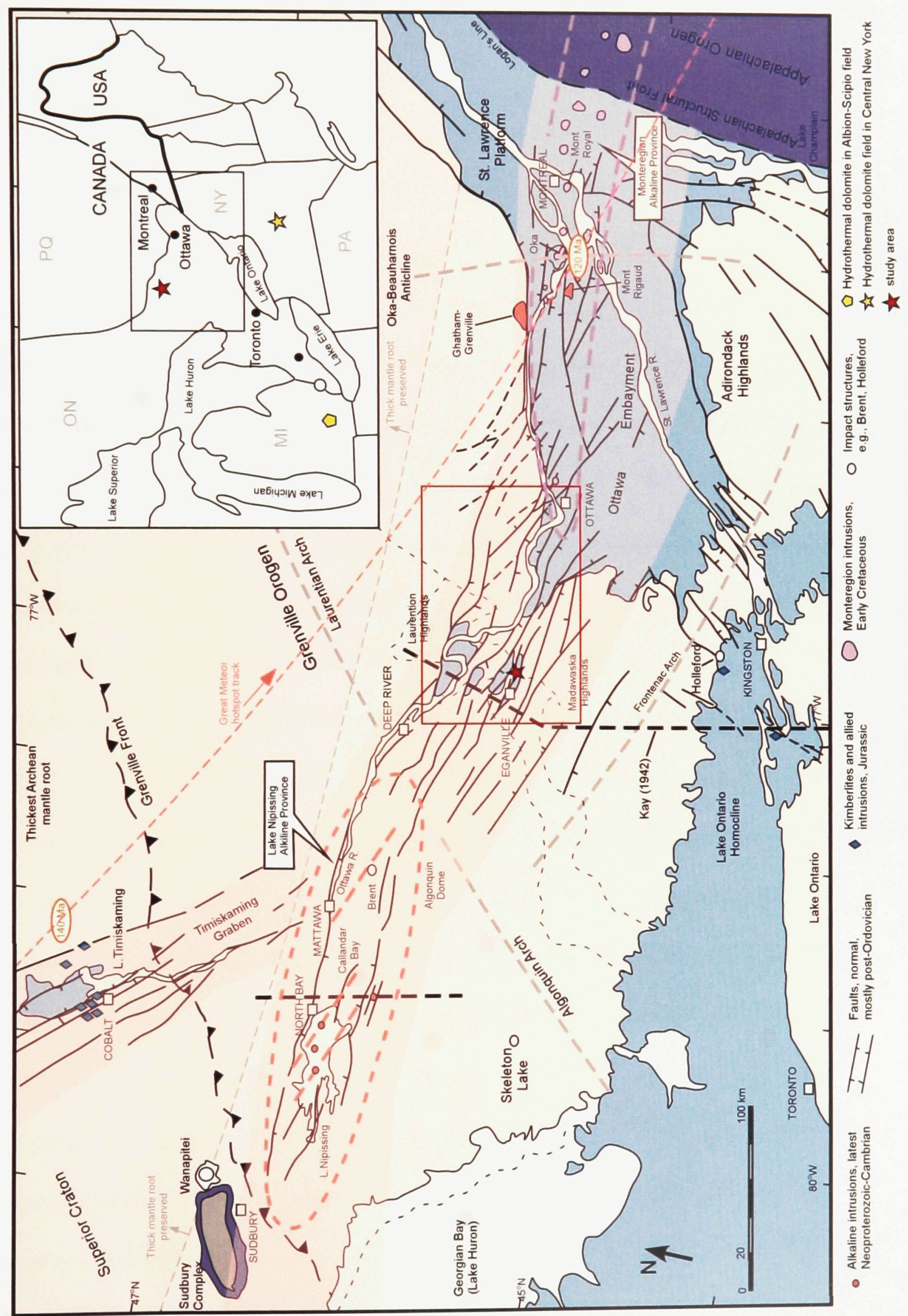


Watertown succession in eastern Ontario is equivalent to the Black River Group, and the younger units are equivalent to the Trenton Group. In general, this succession represents an upsection change from peritidal to open-marine, subtidal platform deposition, marking an increase in platform circulation and water linked to progressively increased rates of subsidence driven by distal plate-boundary loading (Brett and Baird, 2002; Ettensohn, 2008). In eastern Ontario, the Ottawa Group carbonate platform foundered by Maysvillian time through increased subsidence and local block faulting (Dix and Joliceour, 2011), and was succeeded by, initially, deep-water shale (Billings Formation), then a shallowing upward succession of fine-grained siliciclastics (Carlsbad Formation) often with crinoidal debris along bedding planes (Sharma et al. 2003). This normal marine succession is overlain by mostly red-bed mudrock and fine-grained sandstone of the Queenston Formation, although a shallow-water high energy (ooid) facies marks an initial rapid, local transition (Sharma et al., 2003; Sharma and Dix, 2004).

The elongate shape of the Ottawa Embayment is due in part to the fault block fabric of the Ottawa-Bonnechere Graben (Kay, 1942). The northern boundary of the graben is represented morphologically by the northern escarpment of the Ottawa Valley defined by the Laurentian Highlands of eastern Ontario and southwestern Quebec. The southern boundary is defined locally by the Madawaska, Algonquin, and Adirondack highlands (Figure 1). Several Paleozoic outliers occurring between Pembroke and Arnprior, ON, attest to a once more extensive carbonate platform succession of the Ottawa Group extending west of the present limit of the Ottawa Embayment. These outliers have been mapped as small downfaulted blocks, although faults are not exposed. The outlier geometry is defined by the position and orientation of faults recognized in the adjacent 
Page Facing 6

Figure 2. Distribution of Paleozoic structural outliers northwest of the Ottawa Embayment. The red star represents location of the study area (R.J.Selle quarry). Base map is from Bleeker et al. (2011) with some modifications. 


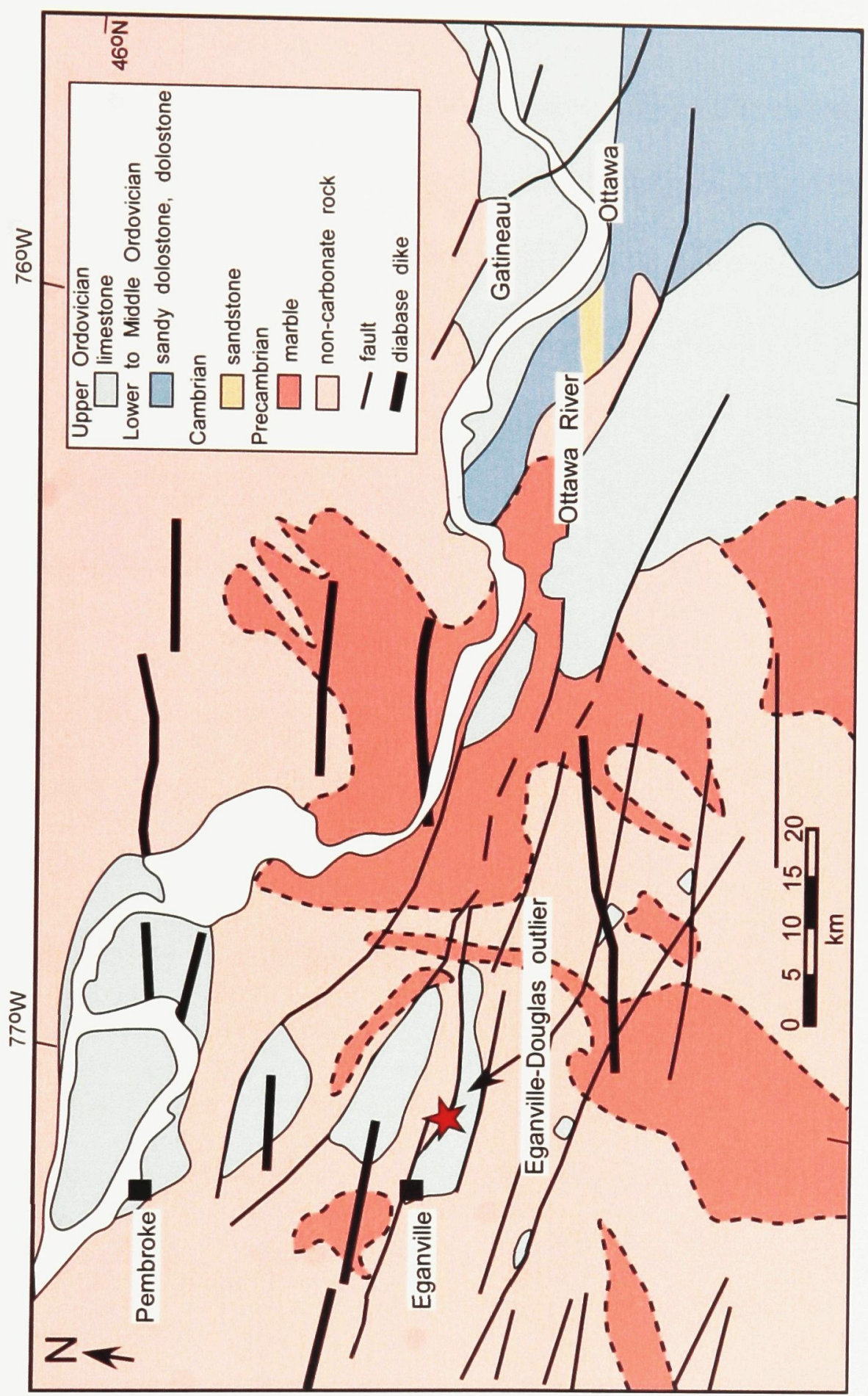


Precambrian terrain (Figure 2). The outliers are surrounded by Grenville crystalline rocks (including marbles), and dikes of the Grenville dike swarm (Kumarapeli, 1985).

The Ottawa-Bonnechere Graben has a complex history. It initially formed during the breakup of the supercontinent Rodinia and formation of the Iapetus Ocean basin in the Neoproterozoic, part of an interpreted failed arm of the St. Lawrence rift system (Burke and Dewey, 1973; Rankin, 1976; Kumarapeli, 1978, 1985). Rifting was preceded by regional intrusion of diabase dykes ( $\sim 700 \mathrm{Ma}$; Murthy, 1971). Additional igneous activity includes formation of alkalic and carbonatite complexes ( $\sim 565 \mathrm{Ma})$ along the present northwest extent of the Ottawa-Bonnechere Graben (Gittins et al., 1967, Doig, 1970; Kumarapeli, 1985). During the rift and drift stages of Iapetus Ocean basin development, from the late Precambrian to Middle Ordovician time, a siliciclastic-to-dolostone stratigraphic succession defines local platform-interior deposition of the Sauk cratonic sequence that underlay the developing epicontinental Laurentian platform. Initial feldspathic and quartz arenites (Potsdam Group; Figure 3) represent initial graben-fill then regional marginal marine arenite successions (Hofmann, 1972; Kumarapeli, 1985; Sanford and Arnott, 2010). Tectonic convergence within the Iapetan ocean basin resulted in the development of the Tippecanoe I cratonic sequence within the Taconic foreland basin along Laurentia. A succession of carbonate platform successions preserved in the Ottawa Embayment record this history (see above). During this period of time, parts of the graben were reactivated (Rocher et al., 2003; Tremblay et al., 2003; Rimando and Benn, 2005; Dix and Al Rodhan, 2006; Kay, 1942; Kumarapeli, 1985; Bleeker et al., 2011). Many of the graben faults are not exposed in the Ottawa Embayment, but associated vein systems occur within the adjacent areas underlain by Precambrian rocks, 
and within the Paleozoic succession itself, and attest to fracturing and local hydrothermal fluid migration (Carignan et al., 1997; Dix and Robinson, 2003). 
Page Facing 9

Figure 3. Comparison of the Lower to Upper Ordovician stratigraphic succession in the Ottawa Embayment, Mohawk Valley, central New York State, and eastern Michigan, within the Albion-Scipio petroleum field. These successions apply to the areas illustrated in the inset map of Figure 1. Based on Bleeker et al. (2011), Smith (2006), and Swezey (2008) 


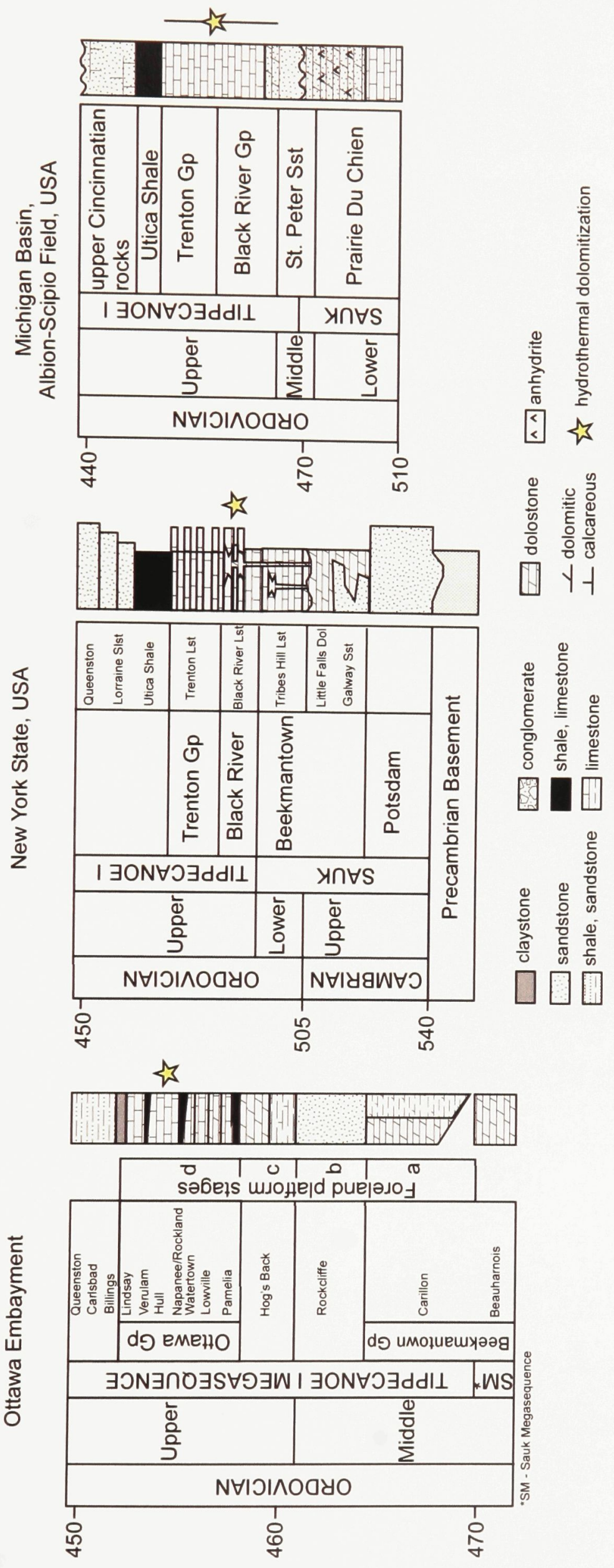




\section{METHODOLOGY}

The R.J. Selle quarry is located between Eganville and Douglas, Ontario (Figure 4), within the Eganville-Douglas Paleozoic outlier. The quarry was mapped in detail for lithostratigraphy, distribution of replacement dolostone, and dolomite veins; the distribution of these mapped with respect to the quarry boundaries as of 2011. Beyond the limits of the quarry, scattered limestone outcrops in the region define the presence of an outlier. They were examined to identify any additional occurrences of dolomitization. Mapping (1:1000) of the R.J.Selle quarry involved defining the distribution of dolostone, and orientation of veins and faults. A geologic map was created using $\operatorname{ArcGIS}$ and Canvas. A representative lithostratigraphic section was measured and described. More than 50 samples were collected for geochemical and thin section analysis.

Standard uncovered thin sections were made by Vancouver Petrographics (Vancouver, BC). These were stained at Carleton University using Alizarin Red-S and potassium ferrocyanide solutions in order to differentiate dolomite and calcite, and their relative iron content. A standard petrographic microscope was used for thin section descriptions: Dunham's (1962) classification of limestone rocks and Sibley and Gregg's (1987) classification of dolomite textures were used for petrographic and field descriptions.

Dolomite and calcite geochemistry were determined from polished thin sections using electron microprobe analysis (Carleton University). A Camebax MBX Electron Microprobe equipped with four wavelength WDX X-ray spectrometers was used to 
analyze following elements from polished thin sections: $\mathrm{Ca}, \mathrm{Mg}, \mathrm{Fe}, \mathrm{Mn}, \mathrm{Sr}, \mathrm{Na}, \mathrm{Ba}$ and Si.

Cathodoluminesence was examined at Carleton University using a Nuclide ELM-2 luminoscope with operating conditions of $12 \mathrm{kV}, 50 \mathrm{~mA}$, and 40 mtorr, and on the Camebax microprobe using an Electron Optic Services Cathodoluminesence system. Operating conditions were: $15 \mathrm{kV}, 15 \mathrm{~mA}$, and 200 microseconds/pixel dwell time.

Thick (250-300 micron) doubly polished thin sections were prepared at Carleton University for fluid inclusion analysis, supervised by Dr. Robert Linnen at the University of Western Ontario, using a LINKAM THMSG 600 stage calibrated between $-56.6^{\circ} \mathrm{C}$ $\pm 0.1^{\circ} \mathrm{C}, 0.0^{\circ} \mathrm{C} \pm 0.1^{\circ} \mathrm{C}$ and $374^{\circ} \mathrm{C} \pm 1^{\circ} \mathrm{C}$ using SYNFLINC synthetic fluid inclusion standards.

Fluid inclusion decrepitation analysis was done at Carleton University by heating small chips of samples up to $300{ }^{\circ} \mathrm{C}$ in a furnace for 1 hour. Increased fluid pressure would cause inclusion decrepitation and escaping fluids would quickly precipitate on the surface of the chips. Scanning electron microscopy (SEM) was then used to determine, qualitatively, elemental composition. This was carried out at Carleton University using a Tescan Vega-II XMU VPSEM with Oxford Inca Energy 250X EDS elemental analysis.

Stable isotope $(\mathrm{C}, \mathrm{O})$ isotope data for dolomite and calcite were determined at the G.G. Hatch Isotope Laboratory at the University of Ottawa. Sample powders were drilled from slab sections. Exeteiners were kept almost horizontal and the samples were reacted with $0.1 \mathrm{ml}$ of $\mathrm{H}_{3} \mathrm{PO}_{4}$ and capped. All the samples were then flushed and filled with helium for 6-8 minutes. Vials were immediately put for 24 hours in the heated block of 
the GasBench at $25^{\circ} \mathrm{C}$ (calcite) or $50^{\circ} \mathrm{C}$ (dolomite). Values were taken using Delta XP and a Gas Bench II then reported with international standards NBS-18, NBS-19, and LSVEC. Values are referenced to the Vienna PeeDee Belemnite (VPDB) standard.

Trace elements geochemistry associated with bulk solution anlaysis was also determined from selected carbonates samples by ActLabs (Ancaster, ON) using ICP + ICP/MS Ultratrace 2 Aqua Regia extraction. A $0.5 \mathrm{~g}$ sample is digested in aqua regia at $90^{\circ} \mathrm{C}$ in a microprocessor controlled digestion block for 2 hours. The solution is diluted and analyzed by ICP/MS using a Perkin Elmer SCIEX ELAN 6000, 6100 or 9000 ICP/MS.

Finally, strontium isotope analysis of selected calcite, dolomite, and marble samples was carried out at the Isotope Geochemistry \& Geochronology Research Centre (IGGRC) at Carleton University. Very clean carbonate samples without any contomination were dissolved in $2.5 \mathrm{~N} \mathrm{HCl}$, and run through columns of Teflon resin to separate $\mathrm{Sr}$ from Ca. Sr with $\mathrm{H}_{3} \mathrm{PO}_{4}$ as loaded onto a single Ta filament and run at filament temperatures of $1380-1600^{\circ} \mathrm{C}$. Measured isotope ratios were normalized for instrument fractionation to ${ }^{86} \mathrm{Sr} /{ }^{88} \mathrm{Sr}=0.11940$. 


\section{DATA}

\section{Geological framework}

Geology northwest of the erosional margin of the Ottawa Embayment consists of several Paleozoic outliers surrounded by Precambrian rocks (Figure 2). Detail of the local geology for the Eganville-Douglas outlier (Figure 2) is shown in Figure 4. The outlier is not a continuous sheet of limestone, but isolated outcrops presumed once continuous in the region. Paleozoic sedimentary rocks rest nonconformably on Precambrian carbonate metasediments (calcite and dolomite marbles) as well as metamorphosed gabbro and anorthosite, and syenite-monzonite and alkali-suite intrusive rocks (Figure 4; Lumbers, 1980). However, exposures of the contact and what the basal sedimentary lithology might be remain unknown. Additional lithological information pertinent to this study, especially local subsurface occurrences of dolostone, was obtained from a water-well-record dataset for the District of Renfrew (http://www.ene.gov.on.ca). This dataset provides only general rock type information, yet the abundance of limestone and location of Precambrian lithologies matches fairly well with the Lumbers and Vertolli (1980) map of local bedrock geology (Figure 5). Depth of the water wells range from $8 \mathrm{~m}$ to $120 \mathrm{~m}$. From this dataset, a few additional dolostone occurrences (in addition to the R.J. Selle quarry) are identified.

There is a prominent WNW-ESE striking fault that offsets basement Precambrian rocks and runs parallel to or controls the location of the Bonnechere River (Lumbers and Vertolli, 1980). Generally, the graben is mostly bounded by steep near vertical normal faults, due to the fact that slickensided surfaces dominantly dip towards the downthrown 
blocks at high angles. No evidence of significant strike-slip movements exists, but minor strike-slip components can be found locally on slickensided surfaces due to adjustments between subsidiary fault blocks (Kay, 1942; Kumarapeli, 1975). Paleozoic stratigraphy within the outliers dip toward fault scarps (Kay, 1942), and this geometry has subsequently been referred to as "roll-over anticline" (see Bleeker et al., 2011 for crosssections through several outliers).

The principal study area (or Locality 1) is the R.J. Selle quarry (Figure 4), which has been active in the last few years. It is located next to an older abandoned quarry named 4th Chute (Steele-Petrovich, 1984; Derry et al., 1989). Entrance to the quarry is $\sim 2.8 \mathrm{~km}$ NW of the crossing of Fourth Chute Road and the Bonnechere River. Within the quarry, vertical bodies of fine- to coarsely crystal- crystalline replacement and vein dolomite are exposed in the northern and southeastern halves of the quarry. These bodies cross-cut host stratigraphy that consists of thin to medium thick beds of skeletal to peloidal limestone and less abundant lime mudstone. Dolostone bodies strike NW-SE (Figure 6), and are 10s of meters in width. One contains an oblique strike-slip fault along which there was a coincident topographic and structurally defined topographic depression best developed on the eastern side of the quarry. (Most of this expression has since been removed by blasting in Fall 2011.). White coarsely -crystalline dolomite veins, and local breccias cemented by white dolomite occur along the fault (Figure 7). The strike-slip fault and dolostone bodies lie parallel to the northward extension of the regional fault north of the quarry, but oblique (angle $=32^{0}$ ) to the same fault trace east of the quarry (Figure 6). 
Figure 4. Local bedrock geology and distribution of regional faults, modified after Lumbers and Vertolli (1980). The star and the triangle show the location of R.J. Selle Quarry (Location 1) and the road outcrop (Locality 2), respectively. 

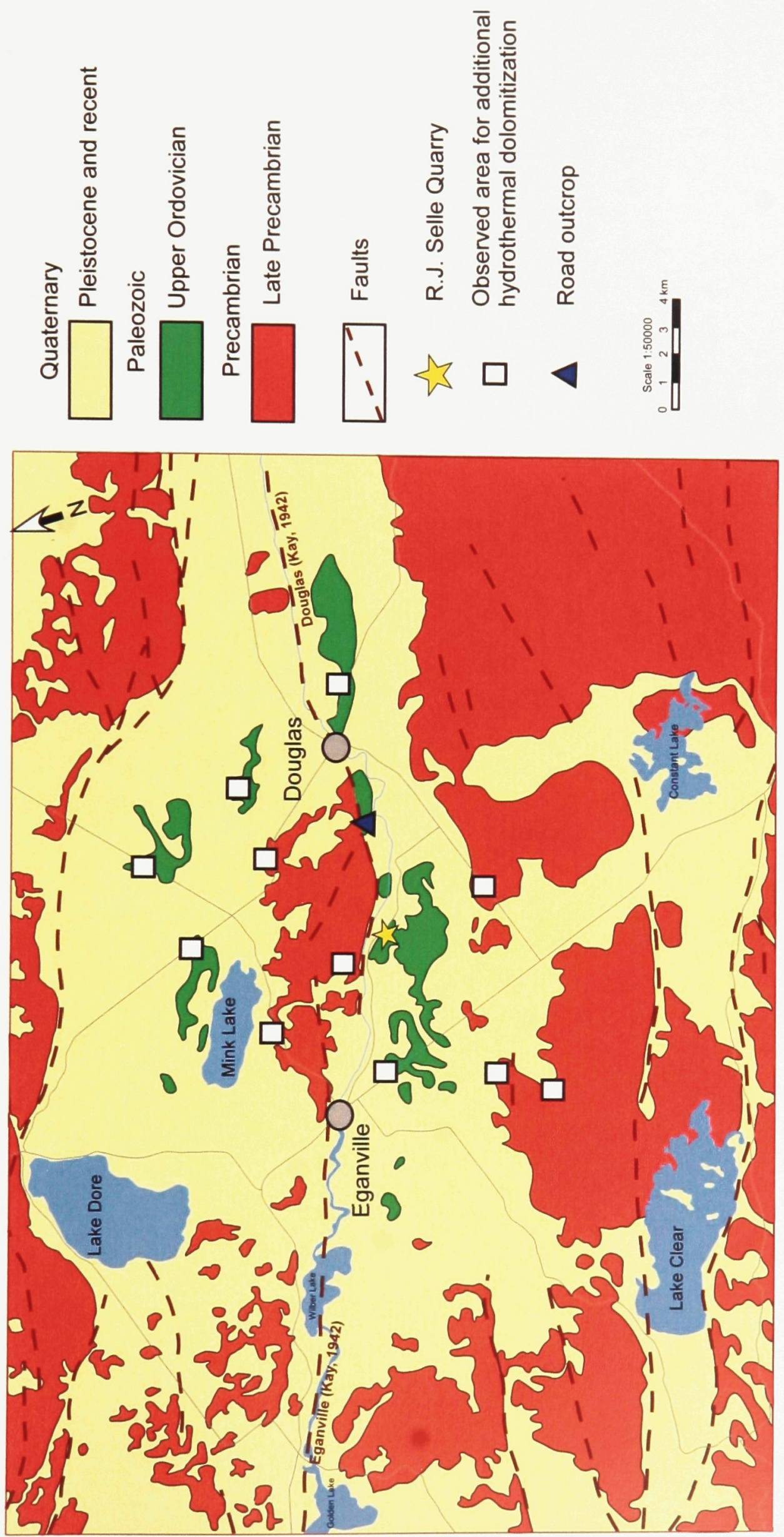
Figure 5. Bedrock geology based on water well information (from WWIS - Water Well Information System-database: http://www.ene.gov.on.ca). The location of the Locality 1 (A) and Locality 2 (B) are indicated along with other anomalous occurrences of dolomite intersected at depth, one of which is spatially associated with faults in the Douglas townsite area. Fault traces are based on the geological map, Pembroke East (eastern part), Preliminary Map P.2356 1 sheet, Scale: 1:63 630 


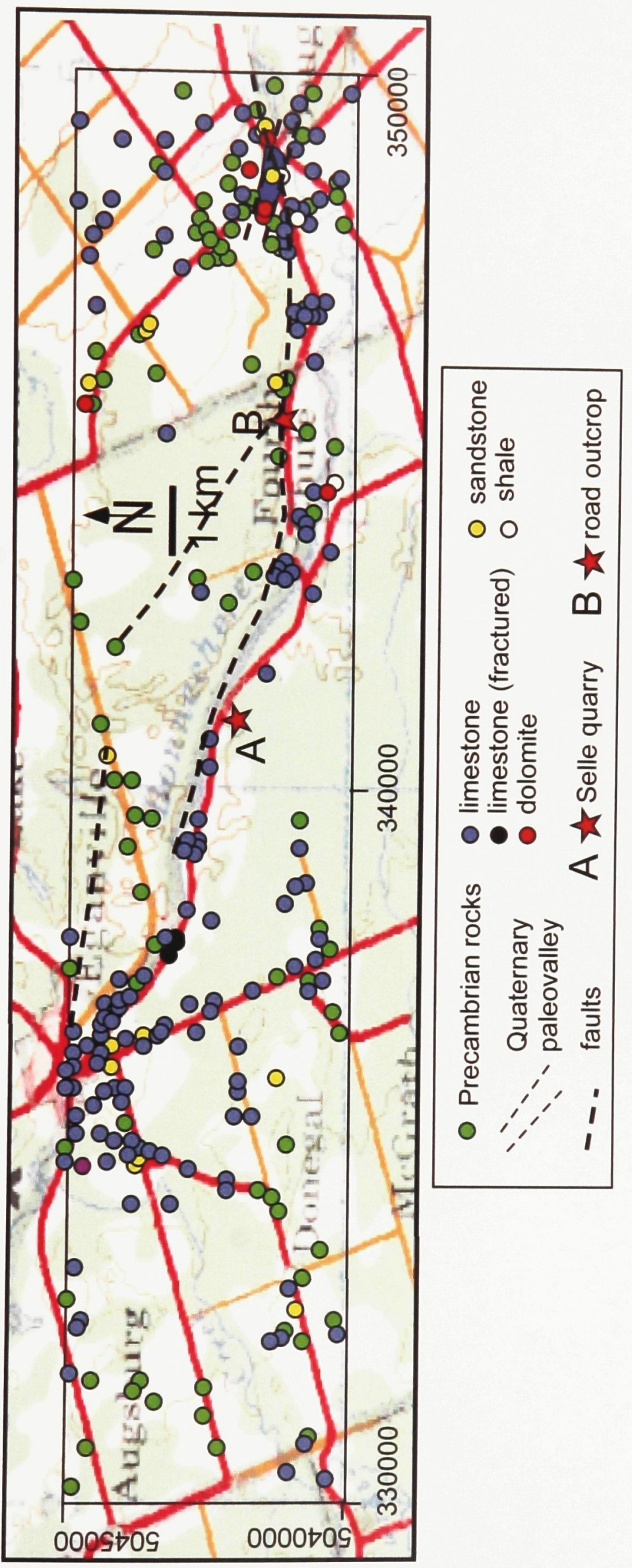


Figure 6. Geological map of Locality 1, shown at a scale of 1:1000, with current (2012) quarry wall limits illustrated by heavy black line. Limestone (LM) and vertical dolostone (DOL) zones are shown. Localities where limestone-dolostone transition are visible are indicated by L1, L2, etc. The trace of local faults are shown in brown, and the interpreted regional fault along the river is from the Lumbers and Vertolli (1980) map. 


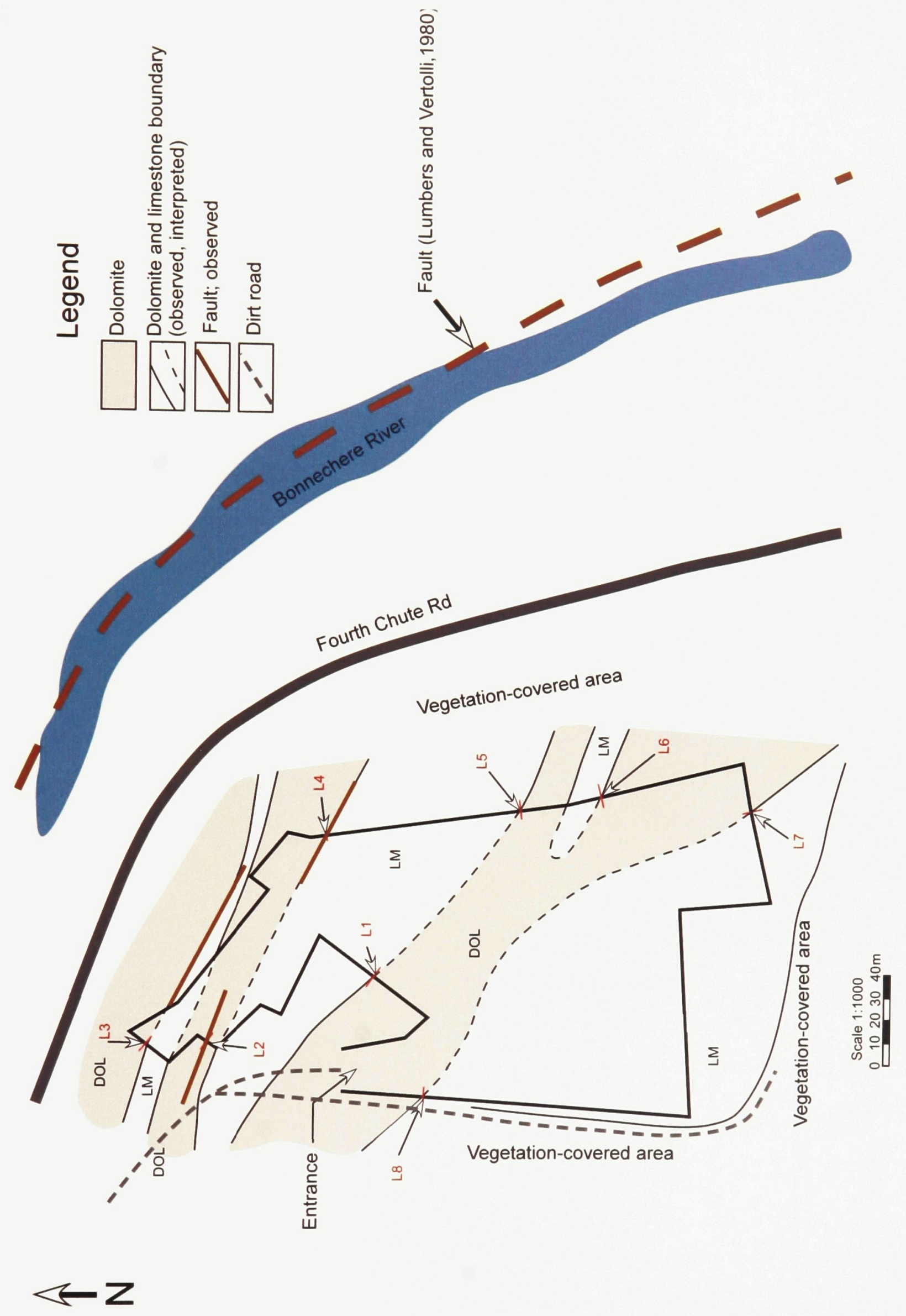


Figure 7. A) View of the northern wall of the quarry showing the trace of a strike-slip fault (red arrow) within a vertical body of dolostone (brown coloured). Note the change in dip from horizontal (left) to $\sim 20^{\circ} \mathrm{N}$. B) A strike-slip fault zone (between the dashed lines) shown in (A) lies sub-parallel to a major WNW-ESE basement fault along the Bonnechère River (see Figure 3). An array of white dolomite veins lie perpendicular to the faulted orientation of bedding (Figure $4 \mathrm{C}$ and D). Wooden stick $(1.2 \mathrm{~m})$ for scale. C) Close-up of the fault zone with white vein dolomite. D) Brecciation associated with white dolomite veins within the fault zone. Each division of wooden stick is $10 \mathrm{~cm}$. 


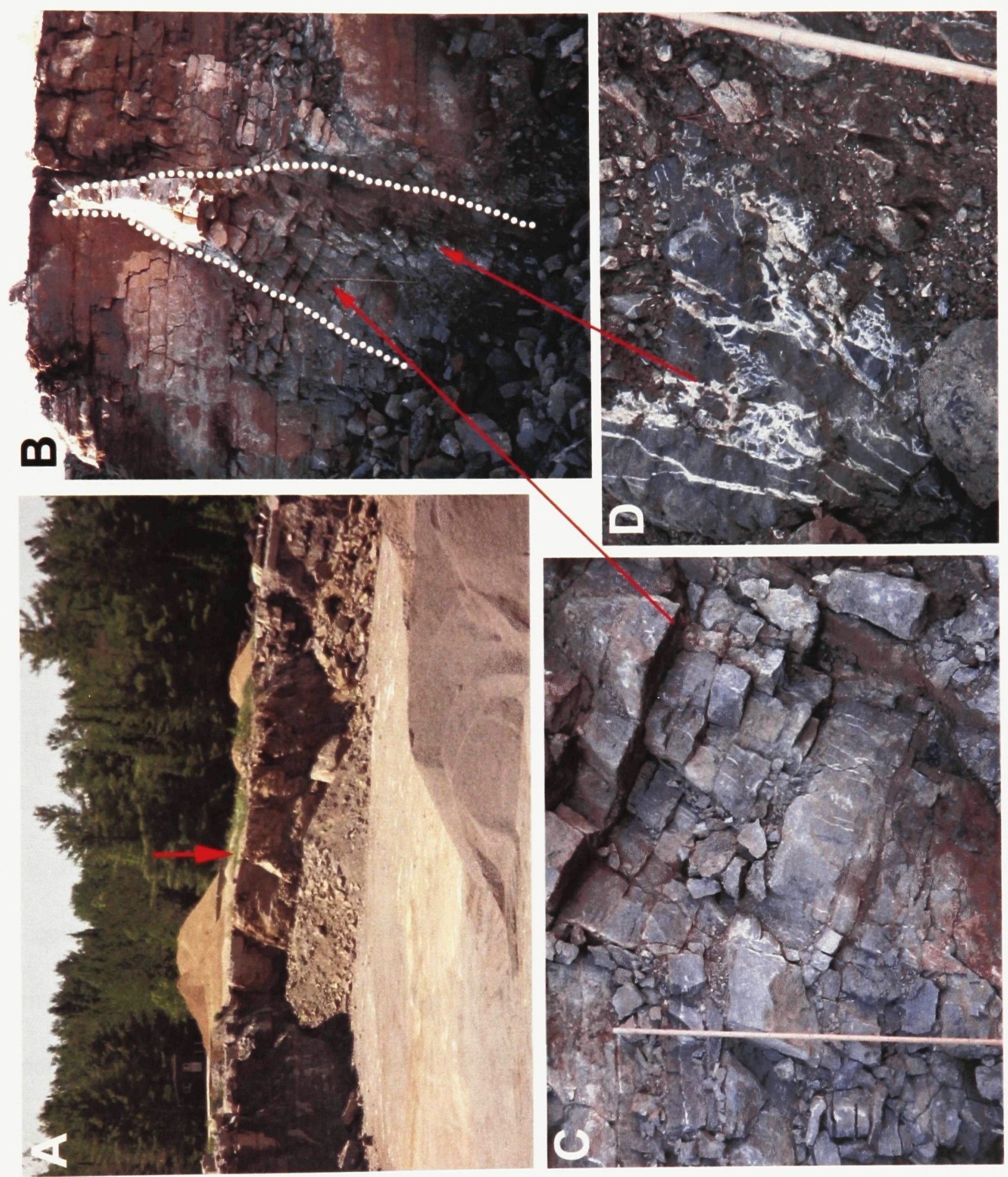




\section{Lithostratigraphy}

\section{Locality 1 (R.J. Selle quarry)}

About 7 to $9 \mathrm{~m}$ of the Ottawa Group limestone is exposed (Figure 8), and is subdivided into five (I-V) lithic units. Regional stratigraphy of the Ottawa Valley is under revision (Dix, unpublished data; Bleeker et al., 2011), but the lithofacies suite suggests that these strata are equivalent to the Hull Formation (Figure 3; Bleeker et al., 2011). A summary of the section exposed in the quarry follows:

Five lithic units are recognized, segregated on the basis of prominent shale beds, 4-5 $\mathrm{cm}$ in thickness (Figure 8). The lowest (Unit I) is a 1.3-m-thick brownish-grey lime mudstone overlain by a fairly discontinuous grey, coarse-grained packstone to grainstone (25 to $30 \mathrm{~cm}$ ) that contains large colonial corals. Unit II is 1.2 metres thick, and consists of a lowermost grey packstone associated with crinoids, stromatoporoids and corals, overlain by brownish-grey mudstone with crinoids and thinly laminated packstone. Unit III is $\sim 1 \mathrm{~m}$ thick, and consists of bioturbated, grey grainstone. Unit IV is $<1.8$ metres thick, and contains thinly laminated and bioturbated, grey packstone in its lower part, succeeded by laminated grey coarse-grained grainstone; then, thin beds of bioturbated, laminated, grey packstone. Unit $\mathrm{V}$ forms the top of the section in the quarry, and its preserved thickness varies from 1.8 to 2 metres. The unit consists of thin to moderately thick bedded, grey skeletal packstone with abundant crinoids, although crinoidal debris cannot be seen in the lower $40 \mathrm{~cm}$. There are poorly preserved oncoids in the middle of the unit. 
Figure 8. Lithostratigraphy of Locality 1 and photographs illustrating each unit (I-V): A) The lowest, Unit I, interval consists of a brownish-grey lime mudstone with large colonial corals within the upper tens of centimetres. B) Grey coarse-grained packstone to grainstone of Unit I overlain by grey packstone associated with crinoids, stromatoporoids and corals of Unit II, divided by shale bed. C) Erosion surface of Unit III with bioturbated, grey grainstone. D) Grey grainstone of Unit III overlain by thinly laminated and bioturbated, grey packstone of Unit IV, divided by shale beds. E) The top of the section in the quarry Unit $\mathrm{V}$ with moderately thick bedded grey skeletal packstone. 

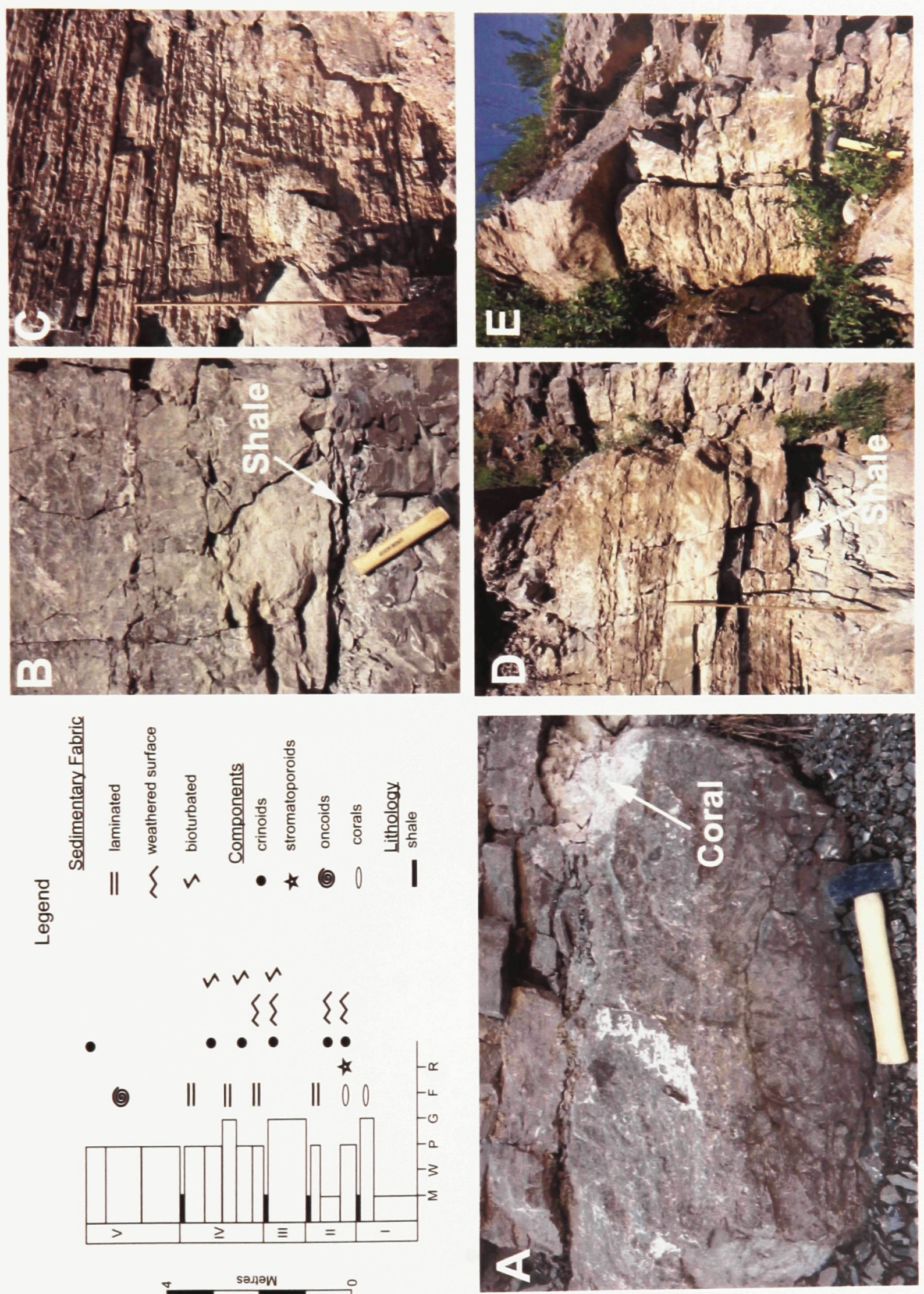


\section{Locality 2 (road outcrop)}

During field work in Summer 2011, limestone outcrops near Locality 1 and within the Eganville-Douglas outlier (Figure 4) were surveyed for evidence of local dolomitization. Additional dolomite occurrence was found only along Fourth Chute Road, at $45^{\circ} 30^{\prime} \mathrm{N}$ latitude, and $76^{\circ} 58^{\prime} \mathrm{W}$ longitude (Figure 9A), about $3 \mathrm{~km}$ southeast of Locality 1 . The outcrop section is small, but exposes narrow veins of dolomite with adjacent zones of replacement dolomite of the host limestone (Figure 9B and C). According to Lumbers and Vertolli (1980), two regional faults adjoin each other in this same area (Figure 4).

The veins are narrow $(0.5 \mathrm{~cm})$, and filled with coarse-grained saddle dolomite, and crosscut fine-grained crinoidal packstone (Figure 9B and C). Extending from the margins of the veins are thin $(4 \mathrm{~cm})$ zones of dolomite that has replaced limestone. The strike and dip of the host rocks is $170^{\circ} / 20 \mathrm{~N}$.' whereas the veins strike $310^{\circ} \mathrm{NW}$ and are vertical. Rocks exposed on the south side of the road dip in the same direction, are lithostratigraphically positioned immediately beneath the north outcrop succession, but have no exposed saddle dolomite veins or replacement dolostone. 
Figure 9. Field attributes of dolomite exposed at Locality 2. A) Exposure of the outcrop along Fourth Chute Road (see Figure 4 for location) Red and white arrows show location of Figure $6 \mathrm{~B}$ and $\mathrm{C}$, respectively. Scale bar $=1 \mathrm{~m}$. B) Fine-grained skeletal packstone (red arrow) with coarse-grained saddle dolomite vein (white arrow). C) Patchily preserved vein margin with coarse-grained saddle dolomite (black arrow) on fine-grained skeletal packstone. The chisel is $\sim 19.5 \mathrm{~cm}$ long. 


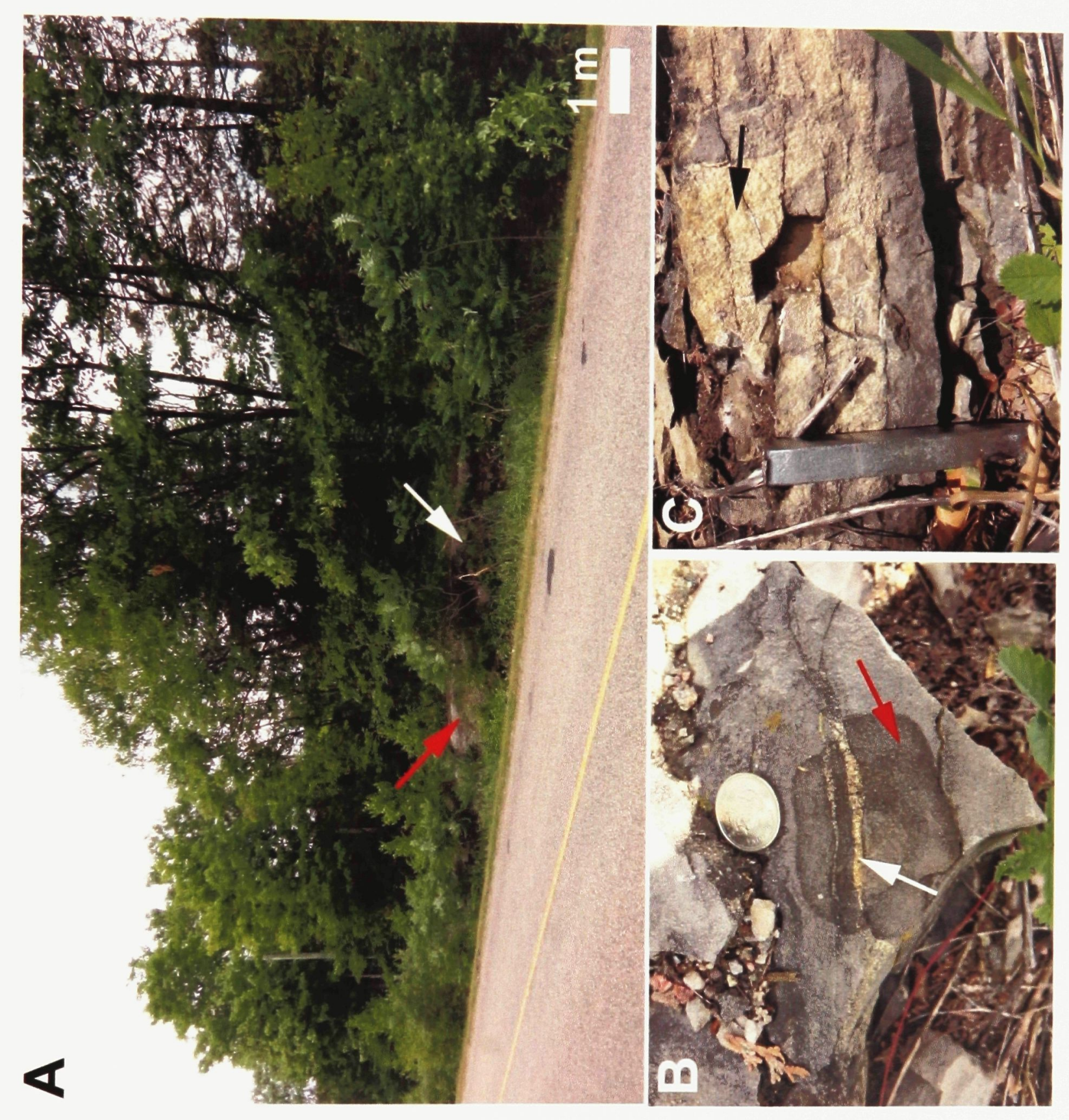




\section{Petrography}

\section{Limestone}

At Locality 1, mudstone at the base of the section consists of peloidal grains, clay wisps and intergranural microspar calcite. The overlying limestone units are dominantly skeletal and peloidal limestones, varying in mud content from packstone to grainstone. Peloidal grains (which are microcrystalline calcite of uncertain origin) vary in size from 5 to 15 microns. Some are angular, but most are well rounded (Figure 10B). Microfabric of uncertain origin occurs in some, illustrating that these are lithoclasts. Intergranular space is filled with microspar calcite forming a cement. Internal pore-space of skeletal material, including crinoids, gastropods, and shelter paleoporosity beneath brachiopod shells, are filled with void-filling calcite cement (Figure 10C and D). Pink staining reveals a nonferroan calcite, which is confirmed by microprobe data (see below).

\section{Dolomite types}

Examination of slab sections and stained thin sections reveal 7 types of dolomite following classification of Sibley and Gregg (1987), according to texture and intracrystalline attributes (Table 1; Figures 11, 12):

RD1 - individual crystals (planar-e) of fine-grained replacement dolomite;

RD2 - local patches of fine-grained replacement (planar-e) dolomite;

RD3 - fine-grained dolomite (planar-e) associated with stylolites;

RD4 - fine-grained replacement (planar-s) dolomite with low intercrystalline porosity; 
RD5 - coarse-grained replacement (planar-e) dolomite with Fe-poor cores and Ferich rims:

SD1 - fracture/void filling fine-grained (nonplanar) saddle dolomite;

SD2 - fracture-void filling coarse grained (nonplanar) saddle dolomite; 
Page Facing 25

Table 1. Detailed description of dolomite types 


\begin{tabular}{|c|c|c|c|c|c|c|c|}
\hline 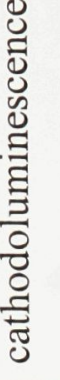 & 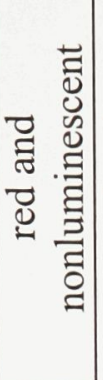 & 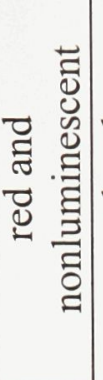 & 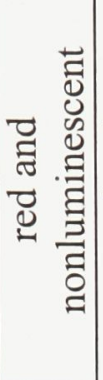 & 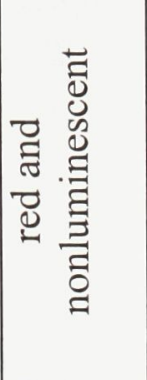 & 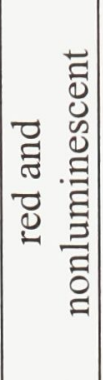 & 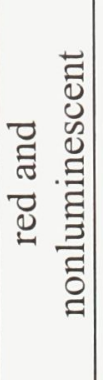 & 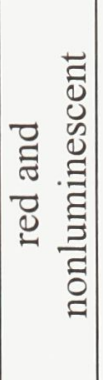 \\
\hline 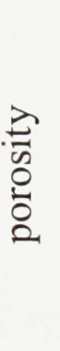 & 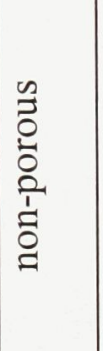 & 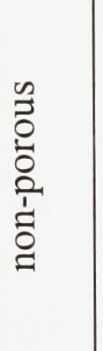 & 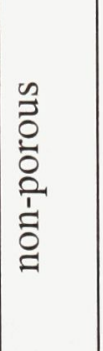 & 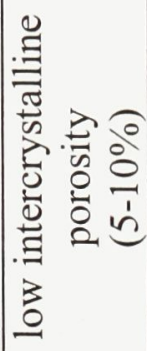 & $\begin{array}{l} \\
0 \\
0 \\
0 \\
0 \\
1 \\
1 \\
i n\end{array}$ & 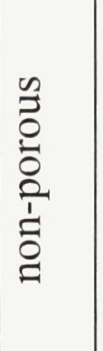 & $\begin{array}{l}0 \\
0 \\
0 \\
0 \\
0 \\
1 \\
\vdots \\
0 \\
0\end{array}$ \\
\hline 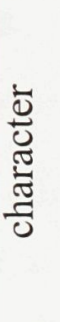 & $\begin{array}{l}\overrightarrow{0} \\
\vec{d} \\
\vec{d} \\
\frac{0}{0} \\
\frac{\pi}{0}\end{array}$ & 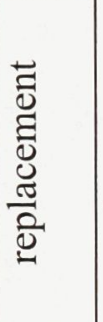 & 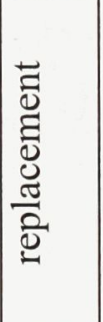 & 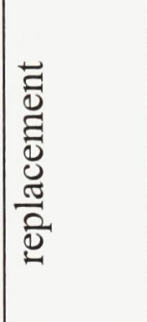 & $\begin{array}{l}\overrightarrow{0} \\
\stackrel{0}{0} \\
0 \\
\frac{0}{0} \\
\frac{0}{0}\end{array}$ & 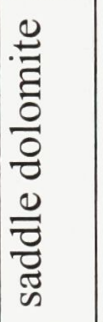 & 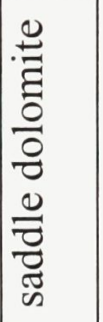 \\
\hline 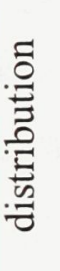 & 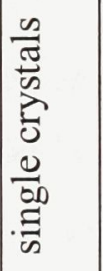 & 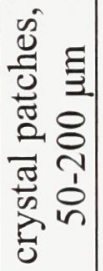 & 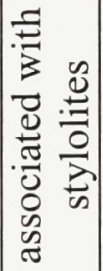 & 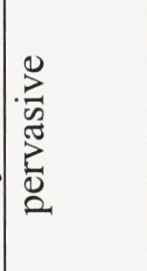 & 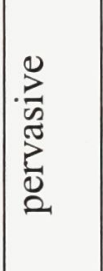 & 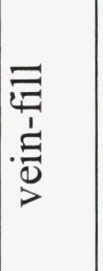 & $\underset{⿱ 亠 䒑}{\mid=}$ \\
\hline 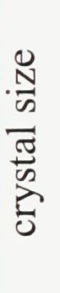 & 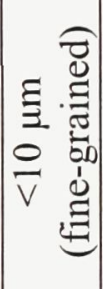 & 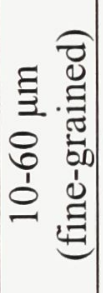 & $\begin{array}{l}\Xi \\
\vdots \\
\frac{1}{1} \\
0\end{array}$ & 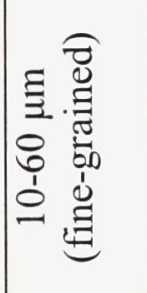 & 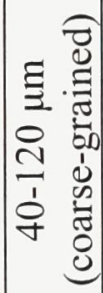 & 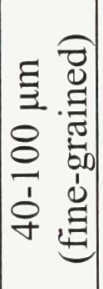 & 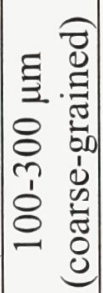 \\
\hline 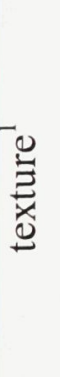 & 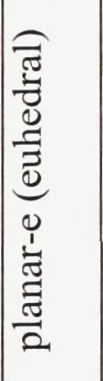 & 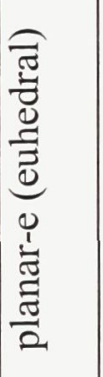 & 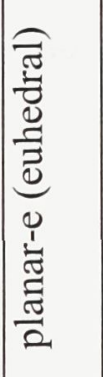 & 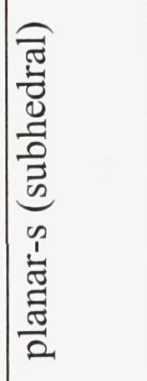 & 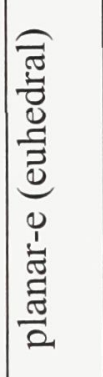 & 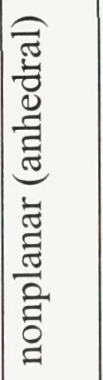 & 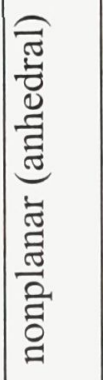 \\
\hline$\underset{\Sigma}{ٍ}$ & $\overrightarrow{\widehat{\theta}}$ & 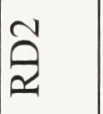 & $\hat{\vec{\imath}}$ & 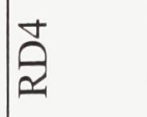 & $\ddot{\partial}$ & $\vec{n}$ & $\hat{\tilde{\omega}}$ \\
\hline 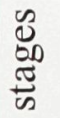 & \multicolumn{4}{|l|}{$\bar{a}$} & $\tilde{\Theta}$ & \multicolumn{2}{|l|}{$\hat{\theta}$} \\
\hline
\end{tabular}


Figure 10. Stained thin-section and polished slab images of host skeletal to peloidal grainstone from Locality 1: A) Polished surface of skeletal to peloidal grainstone with stylolite indicated by white arrows; B) Peloids (white arrows) and intergranular microspar calcite (red arrows). Scale bar $=20 \mu \mathrm{m} ; \mathrm{C}$ ) Bivalve shell (white arrow) and crinoids (red arrow). No primary structure is preserved; bivalve shell is recrystallized whereas crinoid is filled with void-fill blocky calcite cement. Scale bar $=100 \mu \mathrm{m} ; \mathrm{D}$ ) Gastropod with recognizable macrostructure, but represented by a paleomold filled with blocky calcite following dissolution of the original skeletal material. Scale bar $=100 \mu \mathrm{m}$;

D) Brachiopod shell in peloidal grainstone (white arrow). Scale bar $=100 \mu \mathrm{m}$; E) Recrystallized bivalve shell (white arrow) with chert (red arrow). Scale bar=100 $\mu \mathrm{m}$. 

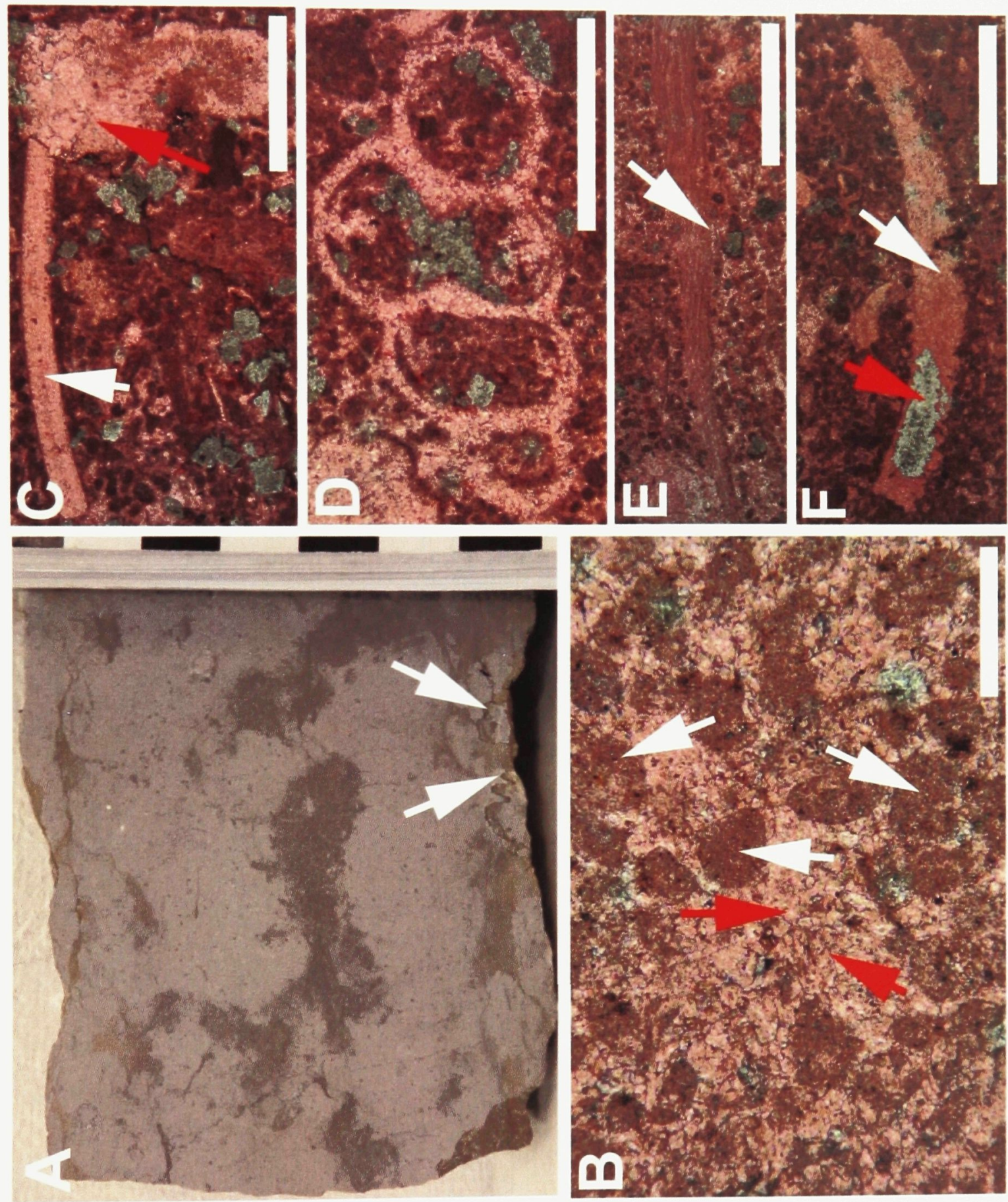
Figure 11. Thin section photomicrographs of dolomite types from Locality 1. All scale bars are $100 \mu \mathrm{m}$. A) RD1 (replacement) dolomite (white arrows) replacing peloids and intergranular microspar calcite in a grainstone. B) RD2 (replacement) dolomite (white arrows). C) RD3 (replacement) dolomite (white arrow) associated with stylolites. RD2 (replacement) dolomite (red arrow). D) RD4 (replacement) dolomite with intercrystalline porosity (white arrow). E) RD5 (replacement) dolomite with more abundant intecrystalline porosity (black arrow), and developed Fe-rich crystal rim (white arrow), and Fe-poor core (red arrow). F) SD1 saddle dolomite crystal with iron (Fe)-rich rim (red arrow), and iron (Fe)-poor core (blue arrow). G) SD1 saddle dolomite (white arrow) filling vein that cross-cuts RD4 (replacement) dolomite (blue arrow). H) Coarser SD2 saddle dolomite (white arrow) 

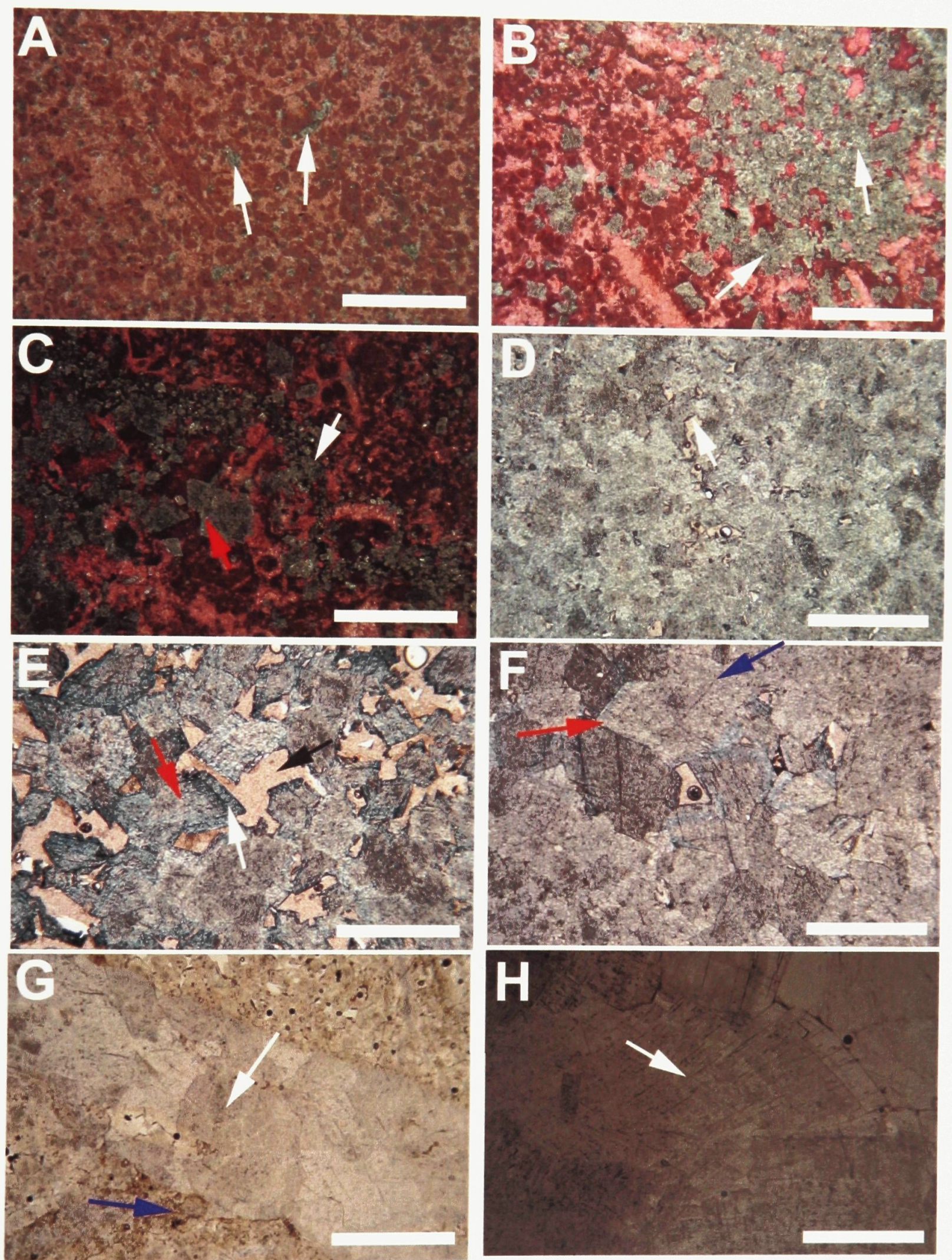
Figure 12. Photomicrographs of dolomite from Locality 2. All scale bars are $100 \mu \mathrm{m}$. A) RD1 (replacement) dolomite (white arrows) replacing skeletal grainstone. B) RD2 (replacement) dolomite (white arrows) and blocky calcite cement (red arrow). C) RD4 (replacement) dolomite with low intecrystalline porosity. D) RD5 (replacement) dolomite (white arrow) with intercrystalline porosity (red arrow). E) SD1 saddle dolomite (white arrow) and blocky calcite cement (red arrow) F) SD2 saddle dolomite (red arrow) 

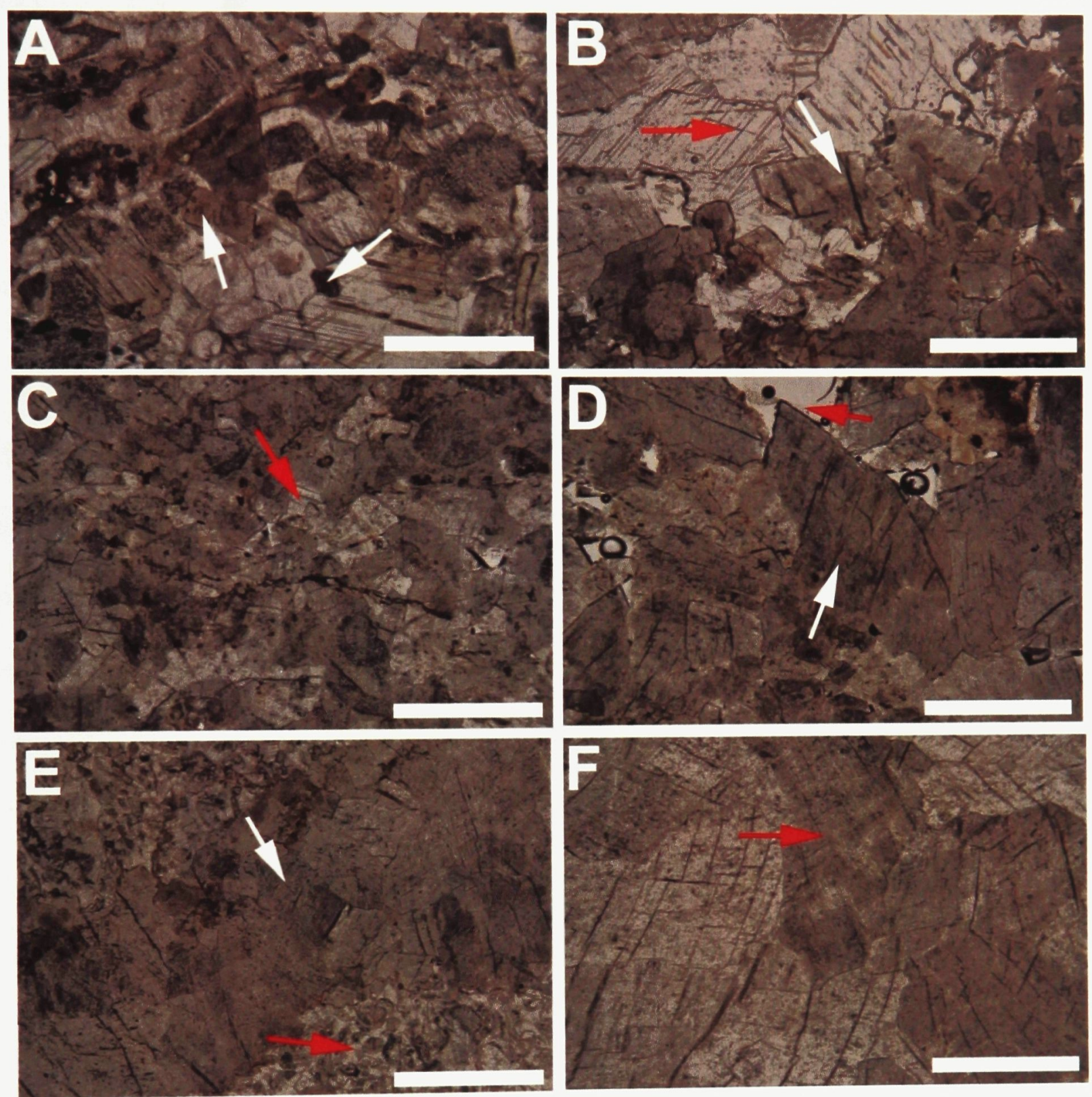


\section{Paragenetic Sequence}

A paragenetic sequence for limestone and dolomite genesis (Table 2) is based on field and petrographic analyses. Prior to formation of any of the dolomite types, field and petrographic relationships demonstrate a history of prior limestone diagenetic alteration yielding an iron-poor limestone (Figure 10A), within which once aragonitic bivalves and gastropods were, respectively, recrystallized and dissolved, their molds filled with blocky calcite cement (Figure 10B and C). Three stages of dolomitization are recognized:

Dolomitization event (D1): Four successive dolomite types are presented (Table 1): RD1 through to RD4, and represent precipitation following or during flexuring. They demonstrate progressive growth in crystal size $(<10$ to $60 \mu \mathrm{m}$; Table 1$)$ and formation of patches of Fe-poor dolomite. RD3 dolomite occurred after some chemical compaction, as indicated by local development of stylolites. Both RD1 and RD2 dolomite predate this history of chemical compaction (Figure 13 and 14). Examples of stylolites cutting RD1 and $\mathrm{RD} 2$ dolomite crystals indicate pressure dissolution after dolomitization. The final product, $\mathrm{RD} 4$ dolomite, is of similar crystal size $10-60 \mu \mathrm{m}$, but subhedral (planar-s) in texture, with appearance of low intercrystalline porosity.

Dolomitization event (D2): The next stage of dolomitization took place after development of RD4 when intercrystalline porosity increased between dolomite crystals. As a result, coarse-grained replacement dolomite (RD5) with abundant intercrystalline porosity was produced.

Dolomization event (D3): Two fracture/void fill saddle dolomites SD1 and SD2 developed following the D2 event, and represent precipitation following or during 
fracturing, but also can be found in some porosity that developed as a result of RD5 dolomite formation. Saddle dolomites (SD1 and SD2) are nonplanar (anhedral) in texture, but different in crystal sizes (Table 1).

\section{Porosity}

Intercrystalline porosity is mostly associated with RD5 dolomite and is minor with RD4 dolomite. Void spaces which remained after the termination of RD5 replacement dolomite later were largely filled by SD1 and SD2 type of dolomites. Dolomite porosity in the RD5 is approximately $50-60 \%$ and $5-10 \%$ in the RD4 dolomite. 
Page Facing 31

Table 2. Paragenetic sequence of the events as interpreted from petrographic studies from Locality 1 and 2. 


\begin{tabular}{|c|c|c|}
\hline Diagenetic process & Early & \\
\hline Limestone diagenesis & \\
Flexuring, microfractures & \\
Replacement dolomite RD1 & \\
Replacement dolomite RD2 & \\
Stylolitization & \\
Replacement dolomite RD3 & \\
Poplacement dolomite RD4 & \\
Replacement dolomite RD5 & \\
Faulting, Fracturing & \\
Brecciation & \\
Saddle dolomite SD1 & \\
Saddle dolomite SD2 & \\
\hline
\end{tabular}


Figure 13. Stained thin section photomicrograph (A) and backscattered electron (B) images of stylolites cross-cutting dolomite crystals. A) RD3 dolomite crystals (red arrows) associated with stylolites cross cutting RD2 dolomite crystal. Blue arrow is pointing at non-ferroan intergranular microspar calcite. Scale bar is $20 \mu \mathrm{m}$. B) Stylolite (red arrows) is cutting RD2 dolomite crystal (white arrow). Intergranular microspar calcite (black arrow). Scale bar is $50 \mu \mathrm{m}$. 

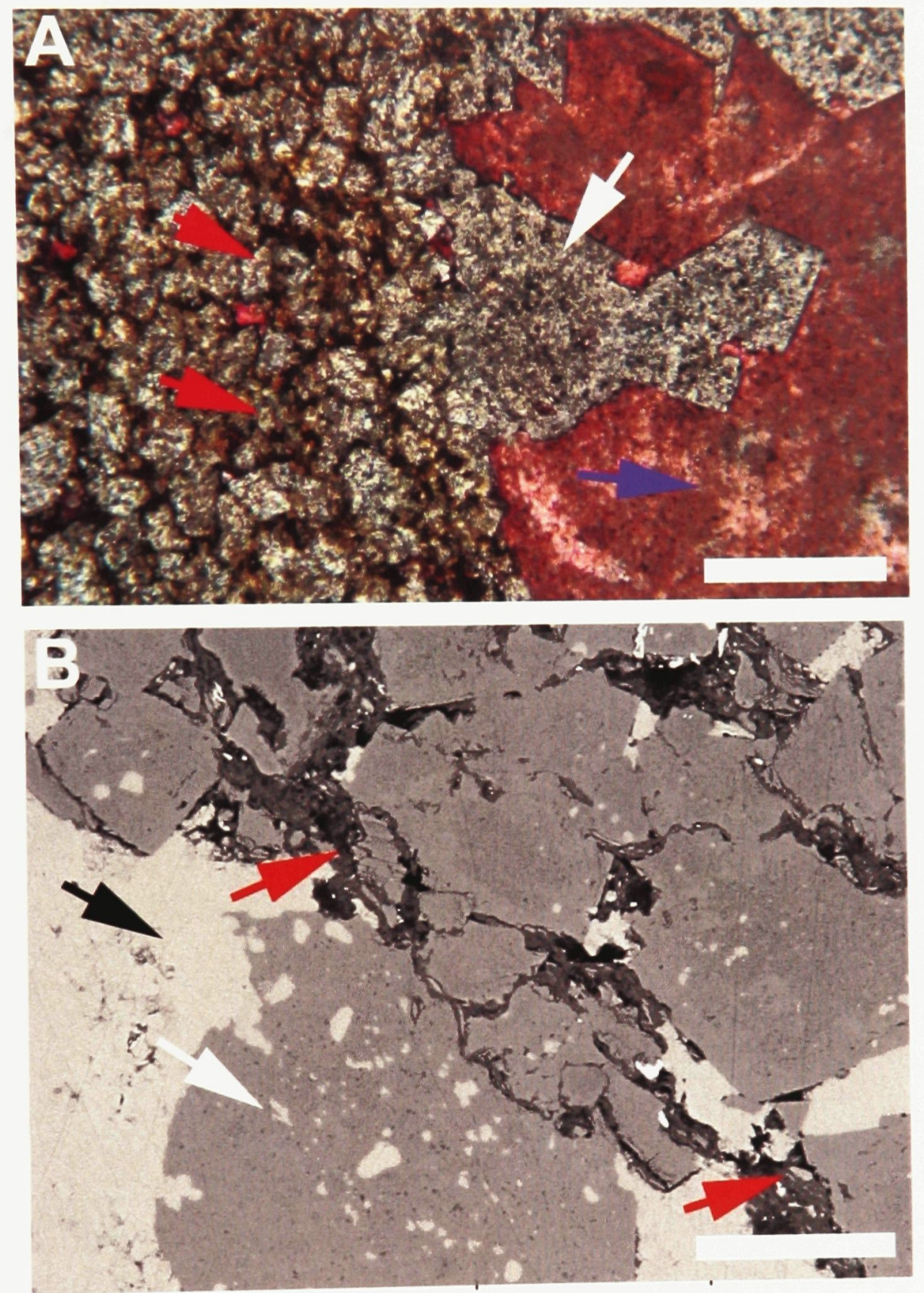
Figure 14. View of the northern wall of the quarry showing abrupt lateral contacts between the host limestone and dolostone. Points A to F show sample locations. Distance between each sample is $1.2 \mathrm{~m}$. Thin section photomicrographs of each sample are illustrated below. Note: dolomite crystal abundance and porosity are increasing toward the dolostone side. Scale bar for stained thin section images is $100 \mu \mathrm{m}$. A) RD1 dolomite (white arrows) replacing peloidal grainstone. B) RD2 dolomite patches (white arrow) replacing peloidal grainstone. C) RD2 dolomite (black arrow) and RD3 dolomite associated with stylolite (white arrow). D) RD4 dolomite with intercrystalline porosity (white arrow). E) RD4 dolomite with intecrystalline porosity (white arrow) and chert (black arrow). F) RD5 dolomite with abundant intecrystalline porosity (red arrow). White arrow indicates iron $(\mathrm{Fe})$-rich dolomite crystal rim, whereas, black arrow points at iron (Fe)-poor core. 

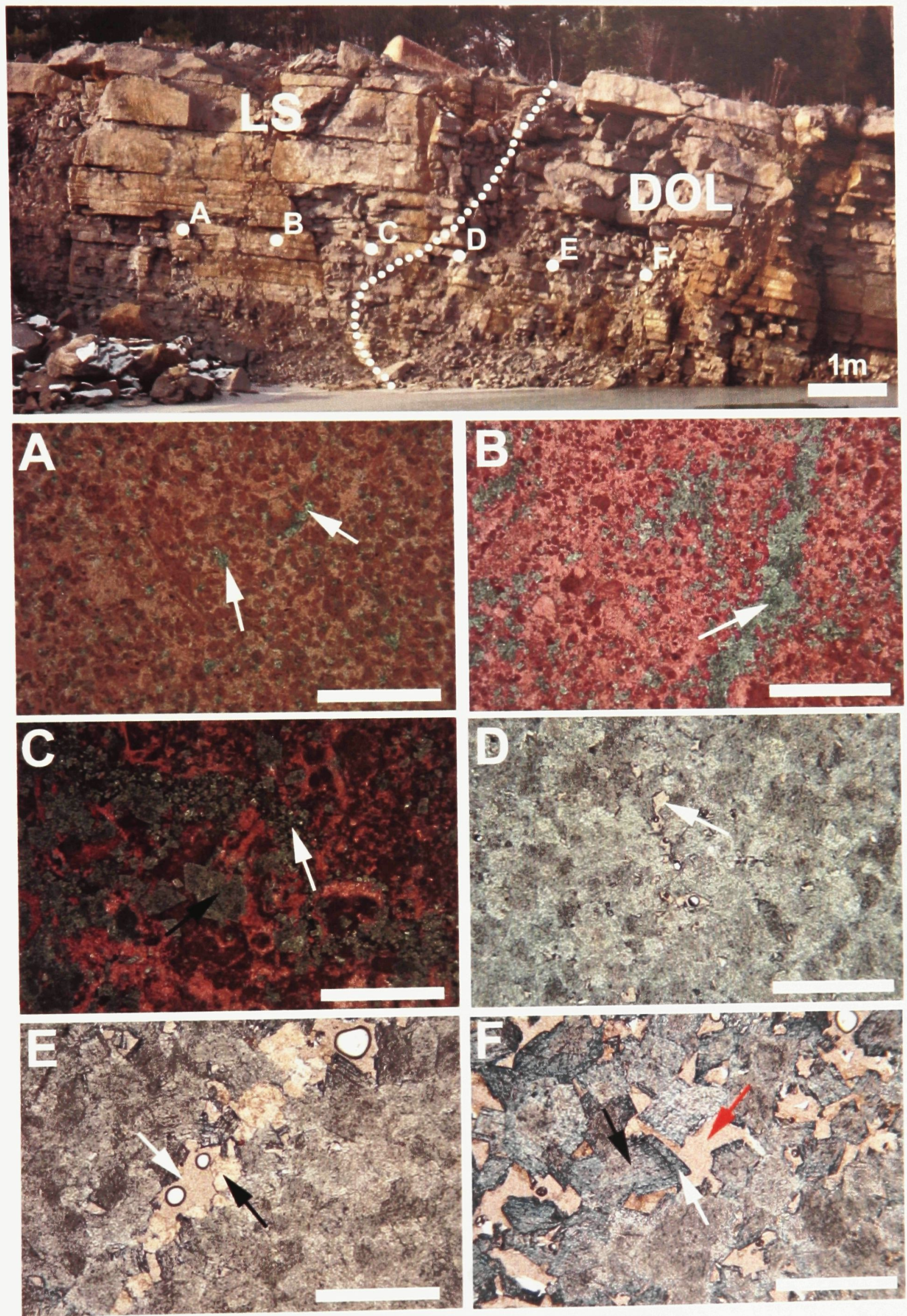


\section{Stable $(\mathrm{C}, \mathbf{O})$ isotopes}

Stable carbon and oxygen isotopes were determined from limestone, replacement (RD3-5) dolomites, and saddle (SD1 and 2) dolomites from Localities 1 and 2. The results are tabulated in Table 3 and illustrated in Figure 15.

Limestones from both outcrop localities have $\delta^{13} \mathrm{C}$ values that range from 0.44 to 2.67 \%o with an average of $1.69 \%$. $\delta^{13} \mathrm{C}$ values for dolomite types is as follows: RD3, 2.04 to $2.82 \%$ with an average of $2.31 \%$; RD4, 1.45 to $3.08 \%$ with an average of $2.26 \%$; RD5, 2.08 to $2.88 \%$, with an average of $2.60 \%$; and, SD1 and SD2 dolomites have $\delta^{13} \mathrm{C}$ values of $1.63 \%$ and $1.96 \%$, respectively.

The $\delta^{18} \mathrm{O}$ values for limestone from both outcrop areas vary from -6.58 to $-12.87 \%$ with an average of $-9.58 \%$, while RD3-5 (replacement) dolomites have more negative values (Figure 15). RD3 dolomite has $\delta^{18} \mathrm{O}$ values from -13.28 to $-13.77 \%$ with an average of $-13.50 \%$. $\delta^{18} \mathrm{O}$ values of RD4 dolomite has values with an average of -13.15 $\%$, ranging from -12.75 to $-13.78 \%$. RD5 dolomite has $\delta^{18} \mathrm{O}$ values ranging from -12.71 to $-13.21 \%$, with an average of $-12.97 \%$. SD1 and SD2 saddle dolomite $\delta^{18} \mathrm{O}$ values are $-12.22 \%$ and $-12.73 \%$, respectively, and are less depleted in $\delta^{18} \mathrm{O}$ compared to RD3-5 (replacement) dolomites.

$\delta^{18} \mathrm{O}_{\text {dol }}$ values are more negative compared to the shallow-water marine-derived dolomite of Upper Ordovician age (Figure 15) based on an expected $+2.6 \%$ shift relative to contemporary marine calcite (Shields et al., 2003; Vasconcelos et al., 2005). 
Figure $15 . \delta^{13} \mathrm{C}$ and $\delta^{18} \mathrm{O}$ values for carbonate samples from Locality 1 and Locality 2. These data are shown relative to field of the hydrothermal dolomite (dashed oval) from the Upper Ordovician limestone (solid rectangle) of the Trenton-Black River succession in New York State, USA (Smith, 2006). Also shown are the predicted fields for Upper Ordovician shallow-water marine dolomite (LOd-sw) based on two different sets $(a, b)$ of model parameters for marine calcite (Shields et al., 2003; Came et al., 2007), and a $\delta^{18} \mathrm{O}_{\text {dol-cal }}$ enrichment of $\sim-2.6$ per mil (Vasconcelos and others, 2005). 


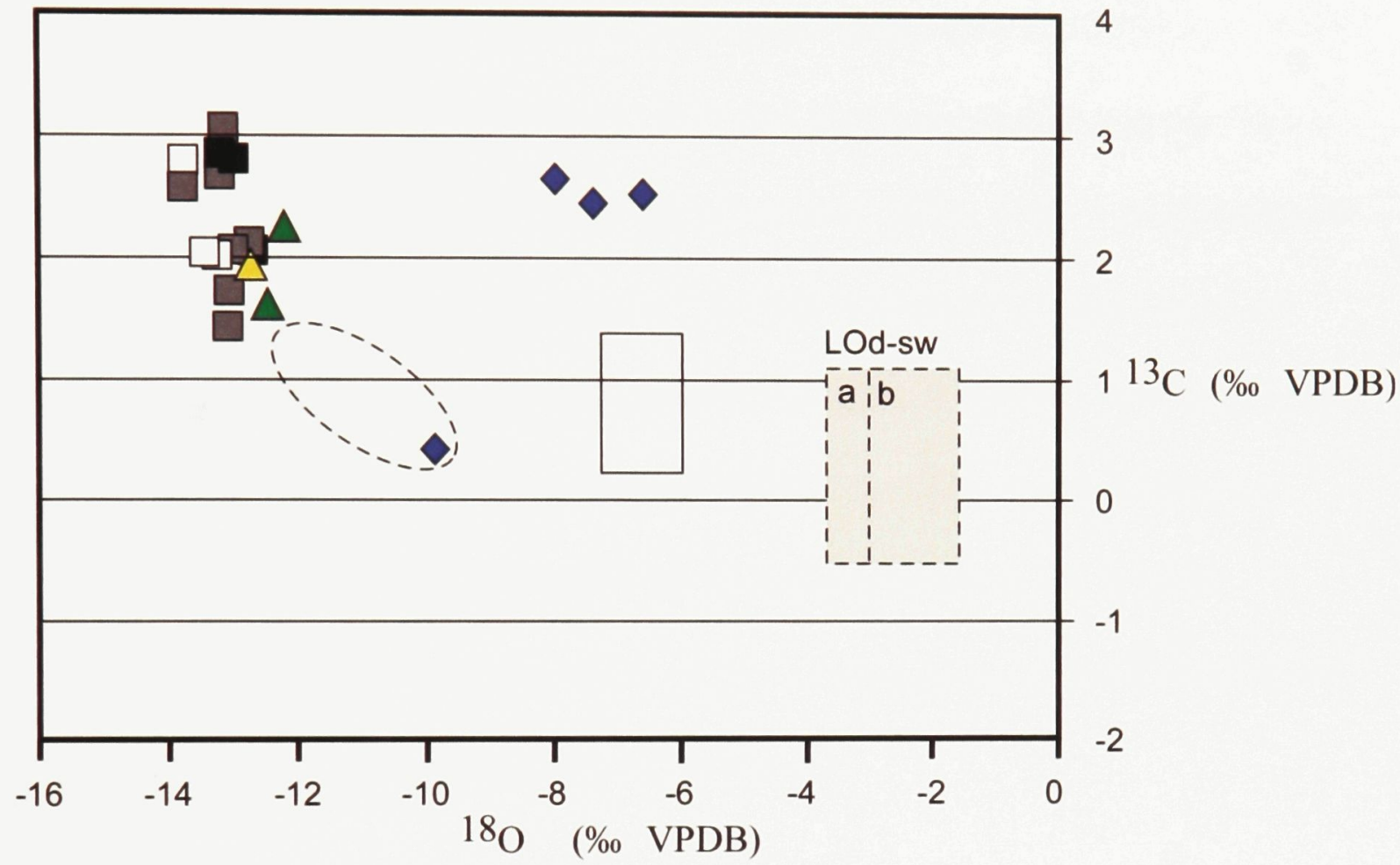

Locality 1 and 2

limestone

$\square$ replacement dolomite (RD3)

$\square$ replacement dolomite (RD4)

$\square$ replacement dolomite (RD5)

$\triangle$ saddle dolomite (SD1)

$\triangle$ saddle dolomite (SD2)
New York State, USA (Smith, 2006)

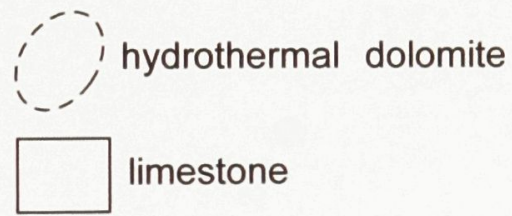




\section{${ }^{87} \mathrm{Sr} /{ }^{86} \mathrm{Sr}$ isotope ratios}

Strontium isotope values were determined for limestone, RD3-5 replacement dolomites, and SD1 and SD2 saddle dolomites collected from the localities 1 and 2. These are summarized in Table 3. Values for limestone range from 0.707885 to 0.707997 with an average of 0.707955 . For reference, the value for Upper Ordovician seawater is estimated to range from 0.7078 to 0.7080 (McArthur at el. 2004). RD3-5 (replacement) dolomite values are slightly more enriched in ${ }^{87} \mathrm{Sr}$. RD3 strontium isotope values are 0.708152 and 0.708827 ; RD4 values range from 0.707945 to 0.708152 , with an average of 0.708060 ; and a value for RD5 dolomite is 0.708083 . Saddle dolomite values are 0.707932 and 0.708004 , no different than Late Ordovician seawater nor the host limestone. The interpretation and conclusion of this data are given in the discussion part (See Geochemical evidence for hydrothermal alteration). 
Page Facing 37

Table 3. Stable isotope and strontium results from Locality 1 and Locality 2. 


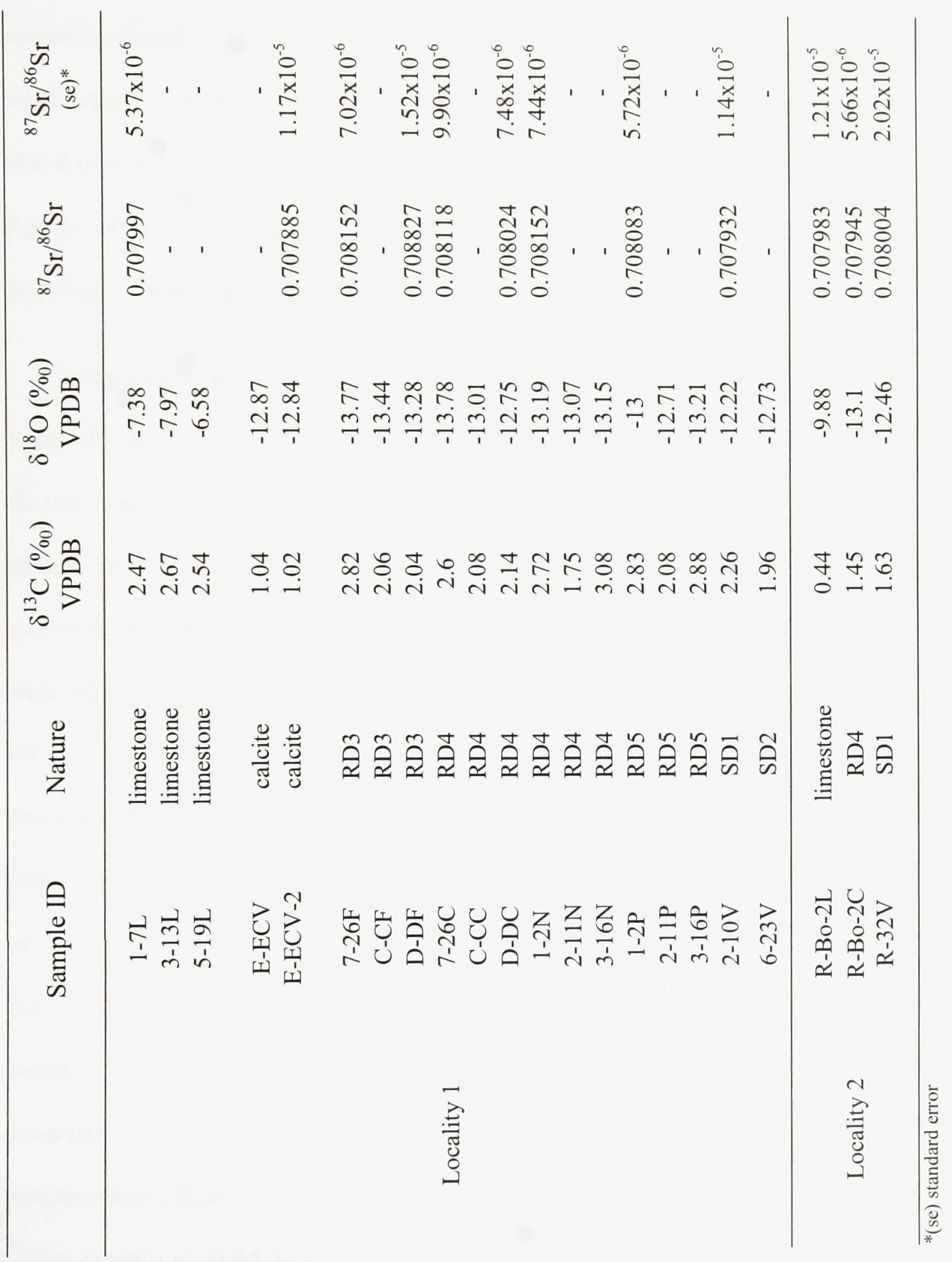




\section{Fluid inclusions}

Fluid inclusions (Figure 16A, B) were identified as primary, secondary or pseudosecondary based on the classification of Goldstein and Reynolds (1994). Primary fluid inclusions were found along crystal growth zones whereas secondary fluid inclusions, also found along crystal growth zone, developed after the growth of the host crystal. Pseudo-secondary inclusions do not follow a specific crystallographic structure, and may be primary or secondary. Primary inclusions formed the targets of this analysis.

Primary fluid inclusions are small, less than $5 \mu \mathrm{m}$ (Figure 16A, B). Nonetheless, vapour bubbles were easily identified. Unfortunately, no fluid inclusions could be frozen despite dropping the temperature to $-196^{\circ} \mathrm{C}$. As a result, no ice-melting temperature or salinity data could be acquired. A sense of the elemental composition of fluid inclusions can be determined qualitatively through artificial decrepitation at $300^{\circ} \mathrm{C}$ (see Methodology). Examination of the fluid-inclusion literature indicates that it is common for $\mathrm{Ca}, \mathrm{Mg}$-chloride basin brines, with salinities in close proximity to the eutectic composition, to remain liquid even at $-190^{\circ} \mathrm{C}$ (Baumgartner and Bakker, 2008), and especially in very small inclusions. Following artificial decrepitation, BSE-SEM analysis of salt precipitates (Figure $16 \mathrm{C}$ and D) identified $\mathrm{Ca}, \mathrm{Mg}, \mathrm{F}, \mathrm{K}$, as well as $\mathrm{Na}$, and $\mathrm{Cl}$. No sulphur (as in sulphate) was recorded suggesting that these host brines were not sulphatebased, but, instead, calcium and magnesium chloride in composition. Fluid inclusions associated with these types of brines typically display the most depressed freezing point temperatures (Brass, 1980). The small size ( $<5$ microns) of the inclusions coupled with this composition could readily prevent freezing (Roedder, 1963). 
Gradual heating of an inclusion bearing a vapour bubble will cause the bubble to shrink and disappear. This refers to the homogenization temperature, and identifies a minimum temperature of precipitation of the host crystal. Data are given in Table 4 and plotted in Figure 17. Fluid inclusions in SD1 and SD2 dolomites have homogenization temperatures ranging from 87.2 to $115^{\circ} \mathrm{C}$, with an average of $100.4^{\circ} \mathrm{C}$. Calcite cement from limestone has homogenization temperatures ranging from 60 to $120^{\circ} \mathrm{C}$, with an average of $86.4^{\circ} \mathrm{C}$ (Figure 17).

Unfortunately, no fluid inclusions were found in RD1-5 dolomites. Therefore, no homogenization temperatures or sense of the elemental composition of fluid inclusions were obtained from these analyses. 
Page Facing 40

Table 4. Fluid inclusion results from Localities 1 and 2. 


\begin{tabular}{|c|c|c|c|c|}
\hline & Sample & Nature & Type $^{*}$ & $\mathrm{Th}{ }^{\circ} \mathrm{C}$ \\
\hline \multirow{10}{*}{ Locality 1} & $\begin{array}{c}7-1(\mathrm{~L} 2-\mathrm{F} 2)^{* *} \\
(\mathrm{n}=6)^{+}\end{array}$ & calcite & primary/ps & $(60-85)^{\#}$ \\
\hline & $\begin{array}{c}7-1(\mathrm{~L} 4) \\
(\mathrm{n}=2)\end{array}$ & calcite & primary/ps & $(120 ; 120)$ \\
\hline & $\begin{array}{c}10-1(\mathrm{~L} 1-\mathrm{F} 1) \\
(\mathrm{n}=1)\end{array}$ & saddle dolomite & primary & 87.2 \\
\hline & $\begin{array}{c}10-1(\mathrm{~L} 1-\mathrm{F} 2) \\
(\mathrm{n}=1)\end{array}$ & saddle dolomite & primary & 102 \\
\hline & $\underset{(\mathrm{n}=5)}{10-1(\mathrm{~L} 1-\mathrm{SF} 1)}$ & saddle dolomite & secondary & $(92.8-108.5)$ \\
\hline & $\begin{array}{c}23-1(\mathrm{~L} 2) \\
\mathrm{n}=1\end{array}$ & saddle dolomite & primary & 100 \\
\hline & $\begin{array}{c}23-1(\mathrm{~L} 1) \\
(\mathrm{n}=1)\end{array}$ & saddle dolomite & primary & 115 \\
\hline & $\underset{(\mathrm{n}=1)}{\mathrm{x}-\mathrm{breccia}(\mathrm{L} 1)}$ & saddle dolomite & primary/ps & 90 \\
\hline & $\underset{(n=1)}{x-v e i n(L 2)}$ & saddle dolomite & primary & 110 \\
\hline & $\underset{(n=1)}{x-\operatorname{vein}(L 3)}$ & saddle dolomite & primary & 107 \\
\hline \multirow{7}{*}{ Locality 2} & $\begin{array}{c}32-1(\mathrm{~L} 2-\mathrm{F} 1) \\
\mathrm{n}=2\end{array}$ & calcite & primary/ps & $(65 ; 80)$ \\
\hline & $\begin{array}{c}32-1(\mathrm{~L} 2-\mathrm{F} 2) \\
\mathrm{n}=2\end{array}$ & calcite & primary/ps & $(83.2 ; 110)$ \\
\hline & $\begin{array}{c}\text { 32-1(L3) } \\
\mathrm{n}=1\end{array}$ & calcite & primary/ps & 85 \\
\hline & $\begin{array}{c}\text { Bo-2-1(L1-F1) } \\
n=1\end{array}$ & saddle dolomite & primary/ps & 95.2 \\
\hline & $\begin{array}{c}\text { Bo-2-1(L1-F2) } \\
\mathrm{n}=1\end{array}$ & saddle dolomite & primary/ps & 105 \\
\hline & $\begin{array}{c}\text { Bo-2-1(L2) } \\
n=1\end{array}$ & saddle dolomite & primary/ps & 100 \\
\hline & $\begin{array}{c}\text { Bo-2-1(L3) } \\
n=1\end{array}$ & saddle dolomite & primary/ps & 102 \\
\hline
\end{tabular}

*classification of fluid inclusions based on Goldstein and Reynolds (1994)

** chip ID; ${ }^{+}$- number $(\mathrm{n})$ of fluid inclusions; ${ }^{-}$- range ( 2 values) or exact number ( 1 value); 
Figure 16. A) Primary fluid inclusions (white arrows) within the calcite cement from limestone sample (inclusion size: 4-10 $\mu \mathrm{m}$ ). Plane-polorized light. B) Primary fluid inclusion (white arrow) within the saddle dolomite crystal (inclusion size $<5 \mu \mathrm{m}$ ). Planepolorized light; C) Backscattered electron image of salt precipitate from a decrepitated fluid inclusion within calcite cement of limestone after being heated to $300^{\circ} \mathrm{C}$. The blocky crystals reveal a $\mathrm{Mg}-\mathrm{Cl}$ composition, whereas the sheet-like precipitate has a $\mathrm{Na}$ $\mathrm{Cl}$ composition. D) Backscattered electron image of precipitated salt from a decrepitated fluid inclusion within saddle dolomite crystal after being heated up to $300^{\circ} \mathrm{C}$. Elements identified include $\mathrm{Ca}, \mathrm{Mg}, \mathrm{F}, \mathrm{K}$, as well as $\mathrm{Na}$, and $\mathrm{Cl}$. 

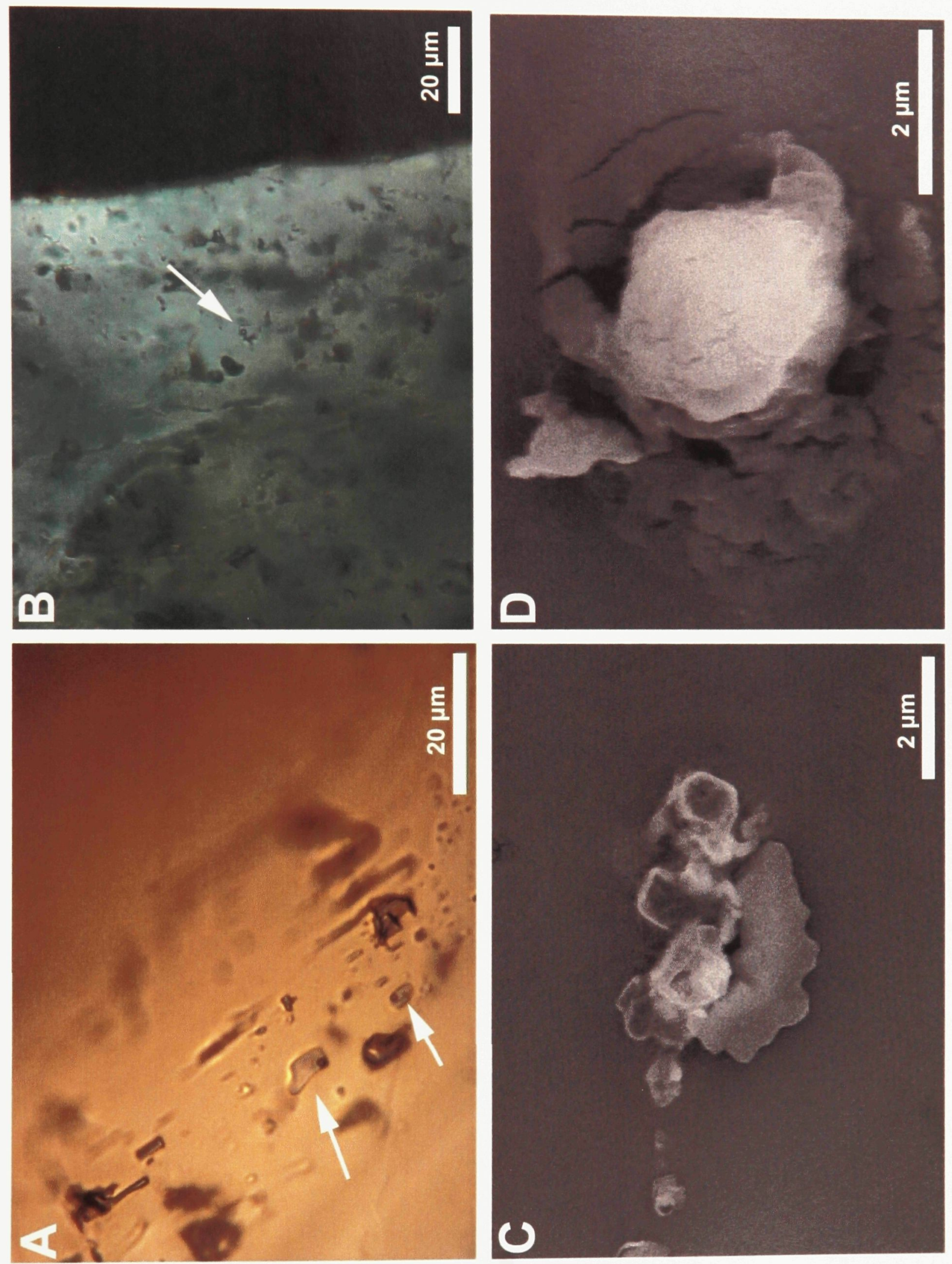
Page Facing 42

Figure 17. Homogenization temperatures $\left(\mathrm{T}^{\circ} \mathrm{C}\right)$ and number of samples from fluid inclusion analysis 


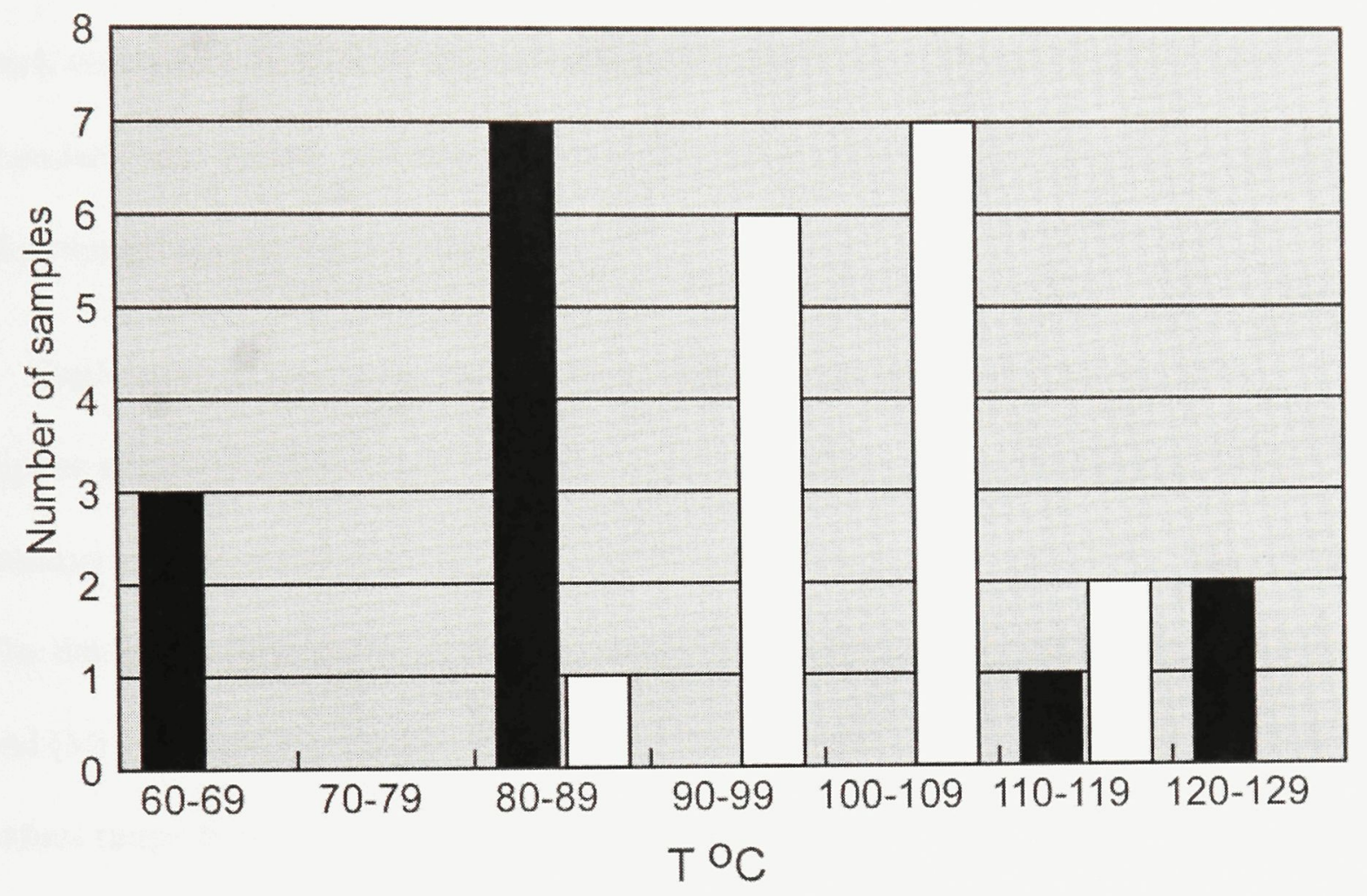

calcite

saddle dolomite 


\section{Trace elements}

A suite of trace element values were determined by solution chemistry from samples of limestone, dolomite and fracture/void filling saddle dolomite from Locality 1 and Locality 2, along with marble from the Precambrian basement exposed in the region. This work was meant to identify any anomalous chemistry that could be traced to fluid chemistry and source, and also to identify the concentration of Sr, which is an indicator of potential seawater involvement.

Bulk samples were used because individual crystals of the rock could not be separated due to microscopic sizes. No anomalous chemistry was noted, and Table 5 summarizes the distribution of some of the major and trace elements in the study area. The data show that dolomites from the study area contain significantly higher (Fe)-iron and $(\mathrm{Mn})$-manganese compared to the limestone (Figure 18). Fe values in the limestone values range from $1200 \mathrm{ppm}$ to $1400 \mathrm{ppm}$ with an average of $1300 \mathrm{ppm}$. The dolomites have Fe values ranging from $7900 \mathrm{ppm}$ to $16700 \mathrm{ppm}$, with an average of $10837,5 \mathrm{ppm}$. The dolomites are also enriched in $\mathrm{Mn}$, with the values ranging from $1260 \mathrm{ppm}$ to 3410 ppm with an average of $2185 \mathrm{ppm}$, whereas the average value for the limestone is only $168 \mathrm{ppm}$. 
Page Facing 44

Table 5. Trace elements results for the samples from Localities 1 and 2. 


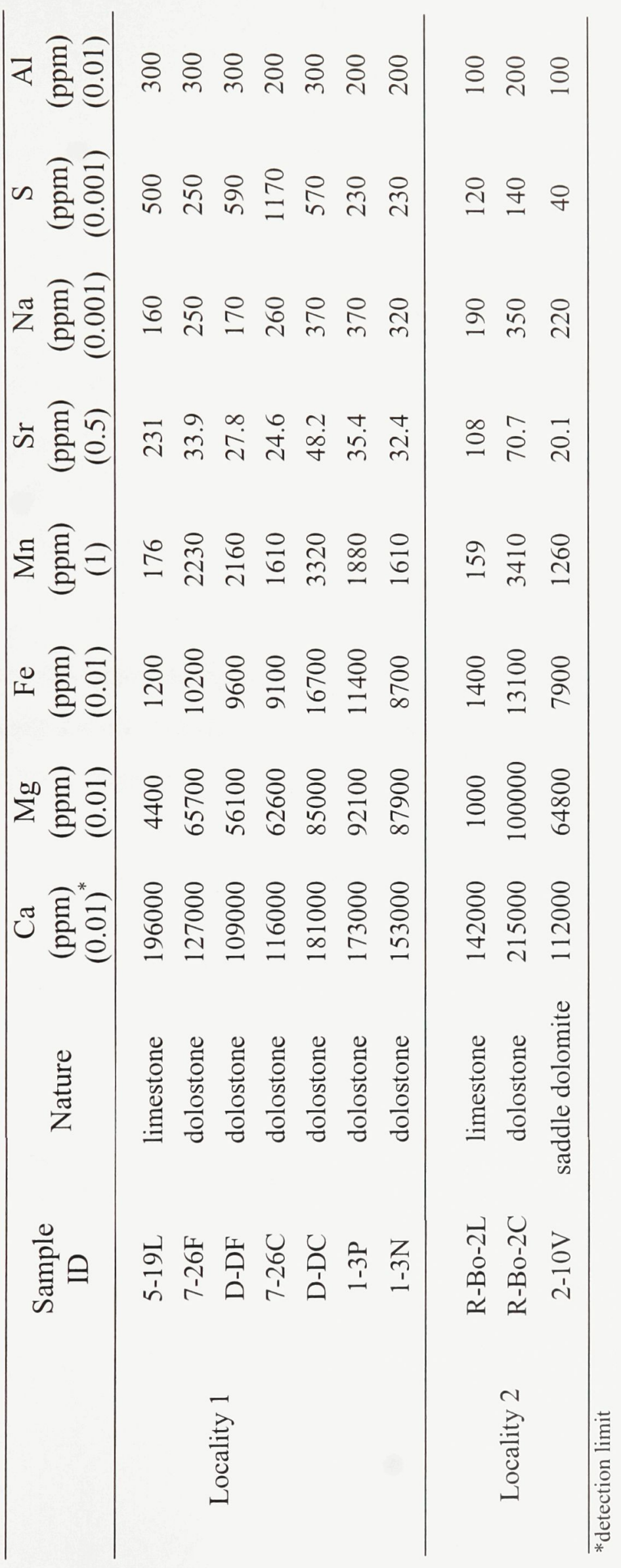


Figure 18. Trace-element composition of limestone and dolomites from Locality 1 and Locality 2 compared to the Upper Ordovician Trenton-Black River hydrothermal dolomite reservoirs data in New York; a - limestone, b - dolomite (Smith, 2006) 


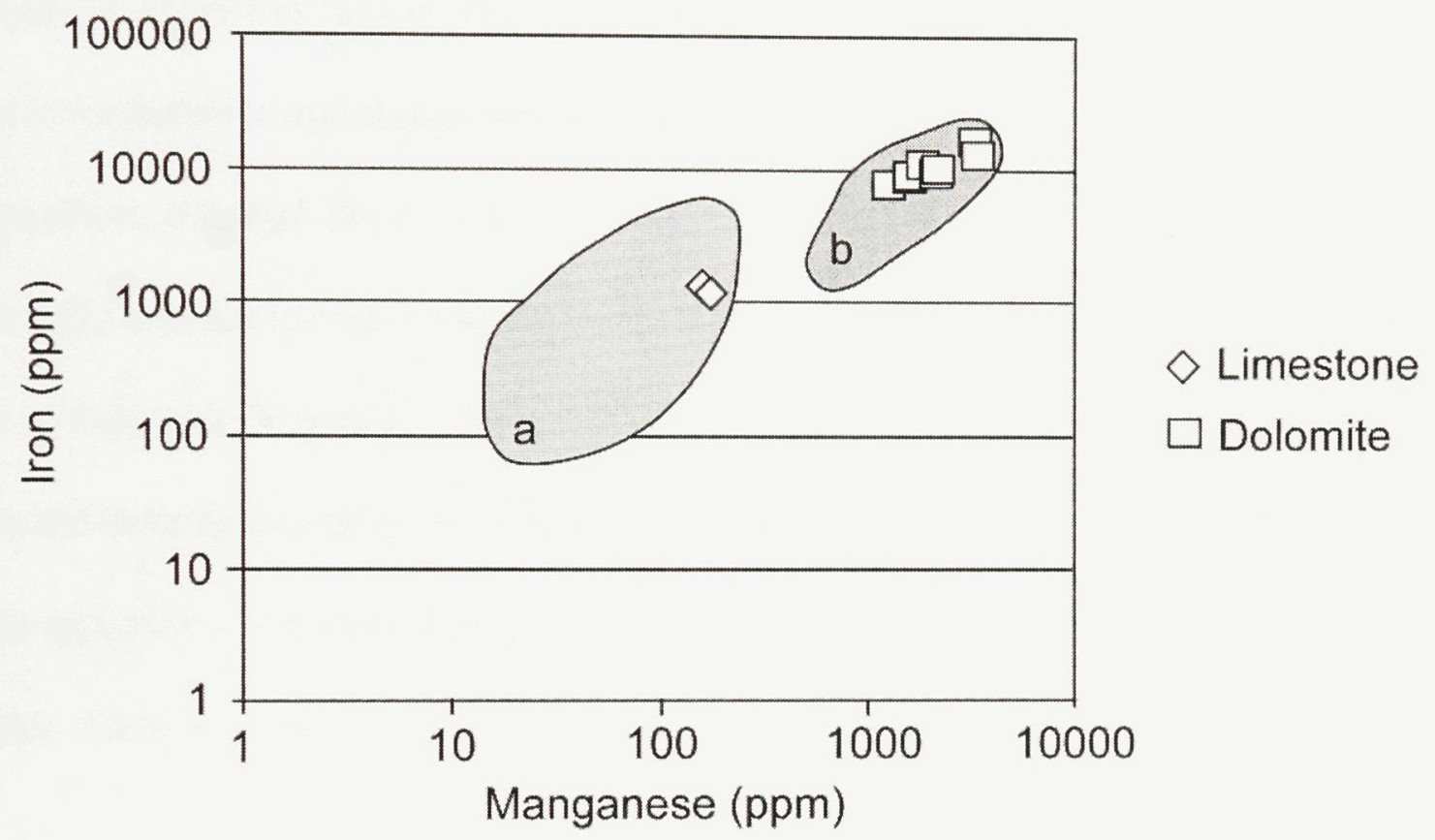




\section{Microprobe analysis}

Electron microprobe was used to analyze and compare the chemical composition of different types of dolomite. This involved determination of $\mathrm{Ca}, \mathrm{Mg}, \mathrm{Sr}, \mathrm{Ba}, \mathrm{Si}, \mathrm{Na}, \mathrm{Fe}$ and $\mathrm{Mn}$ from cores and rims of different types of dolomite as well calcite cement. Data are given in Table 6 and Table 7. $\mathrm{CaO}$ and $\mathrm{MgO}$ values for all dolomite types have averages of 31.09 (wt \%) and 20.22 (wt \%), respectively. Differences in composition might exist between cores and rims of different dolomite types in $\mathrm{FeO}$ and $\mathrm{MnO}$ composition, although the overlap of values is considerable (Figure 19). Cores and rims of the RD5 and SD1 types of dolomite have relatively higher values of $\mathrm{FeO}$ than other types of dolomite (Figure 19). SrO is commonly low for all dolomite types, and it is below the detection limit of the microprobe. Solution chemistry (Table 5) shows $\mathrm{Sr}$ values typically $<100 \mathrm{ppm}$ for dolomite, and between 100-300 ppm for limestone samples. Calcite cement from limestone has low $\mathrm{Mg}, \mathrm{Fe}$, and $\mathrm{Mn}$ concentrations. 
Page Facing 47

Table 6. Microprobe results for different dolomite types 


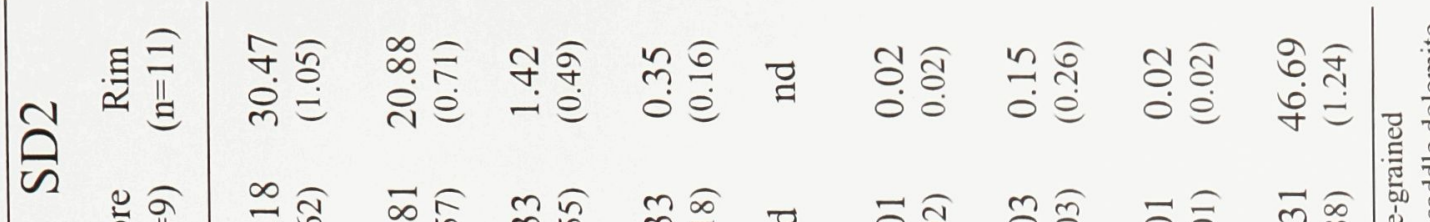

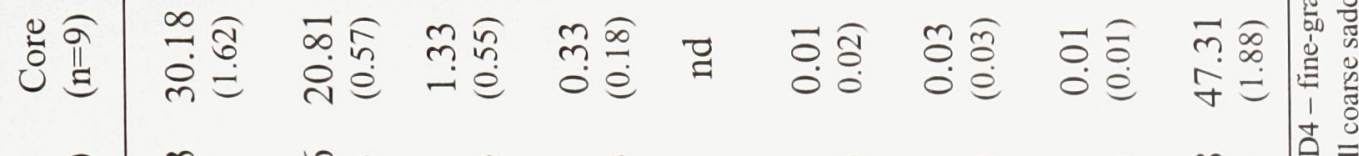

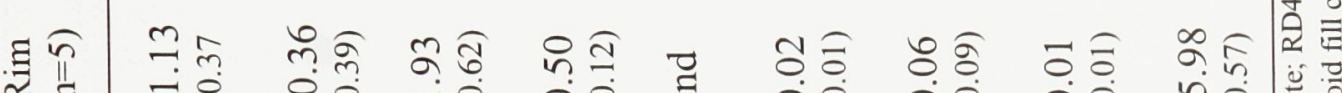

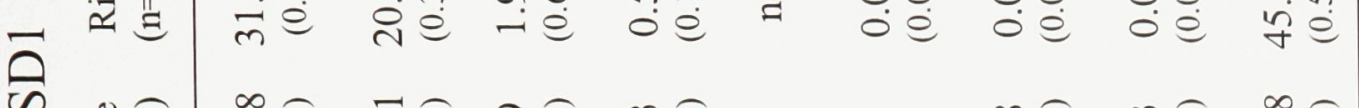

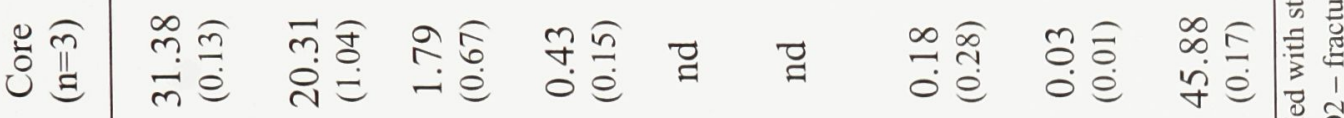

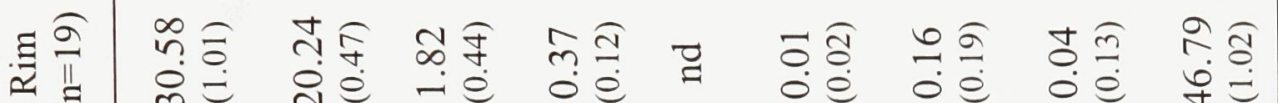

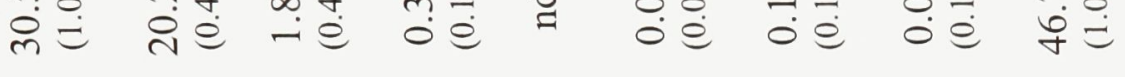

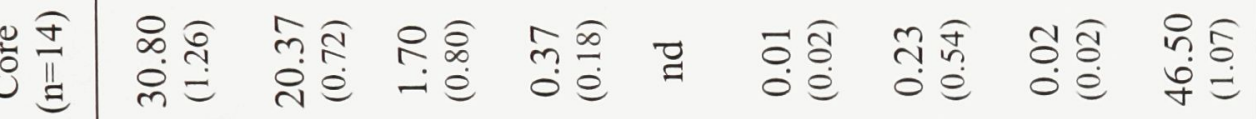

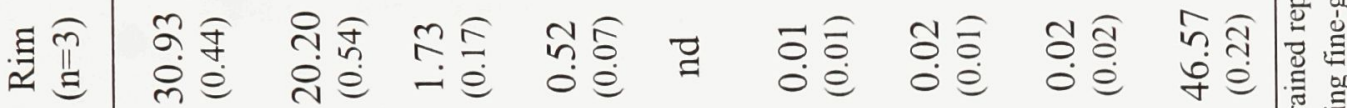
至 ले ते है

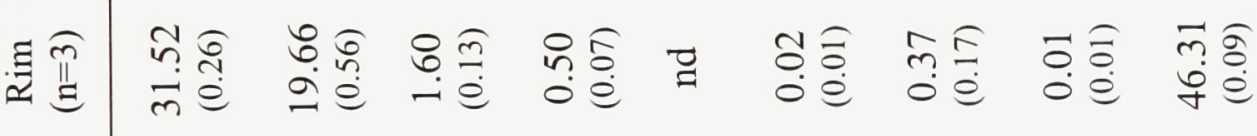
थิ

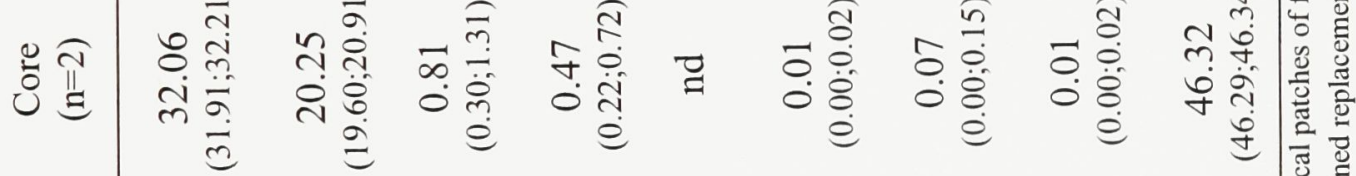
घ $\overline{7}$ ติ

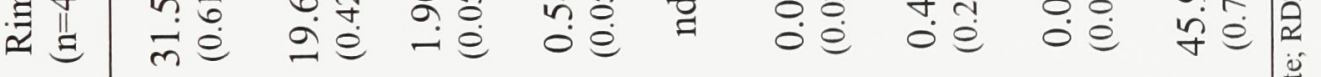

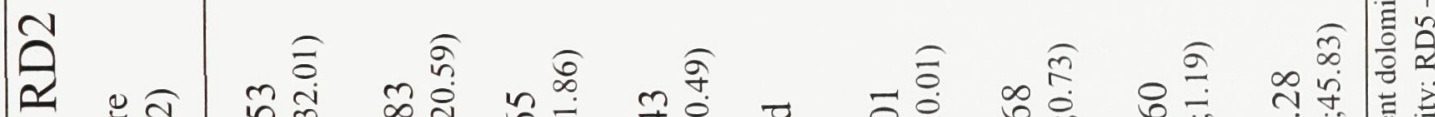

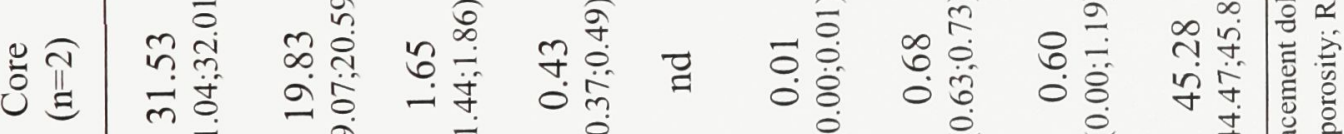

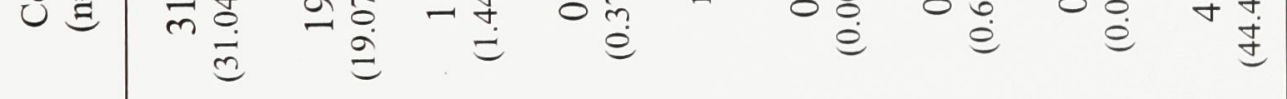

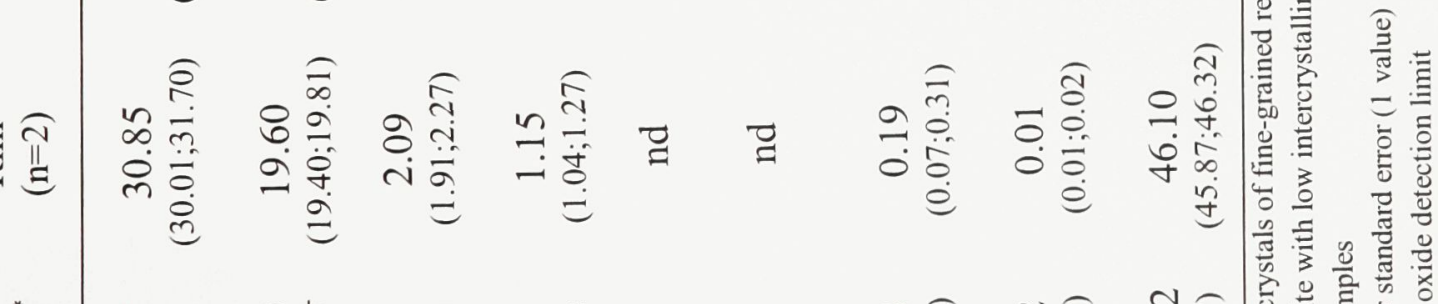

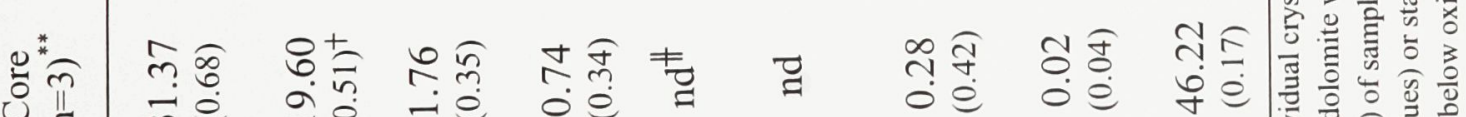

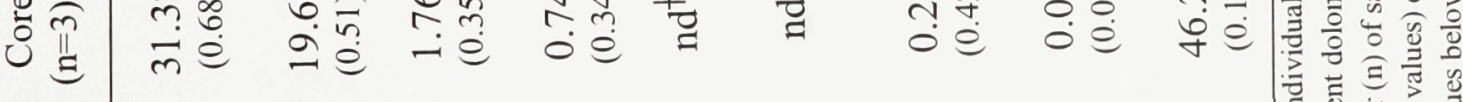
尊旁 
Page Facing 48

Table 7. Microprobe results for calcite cement 


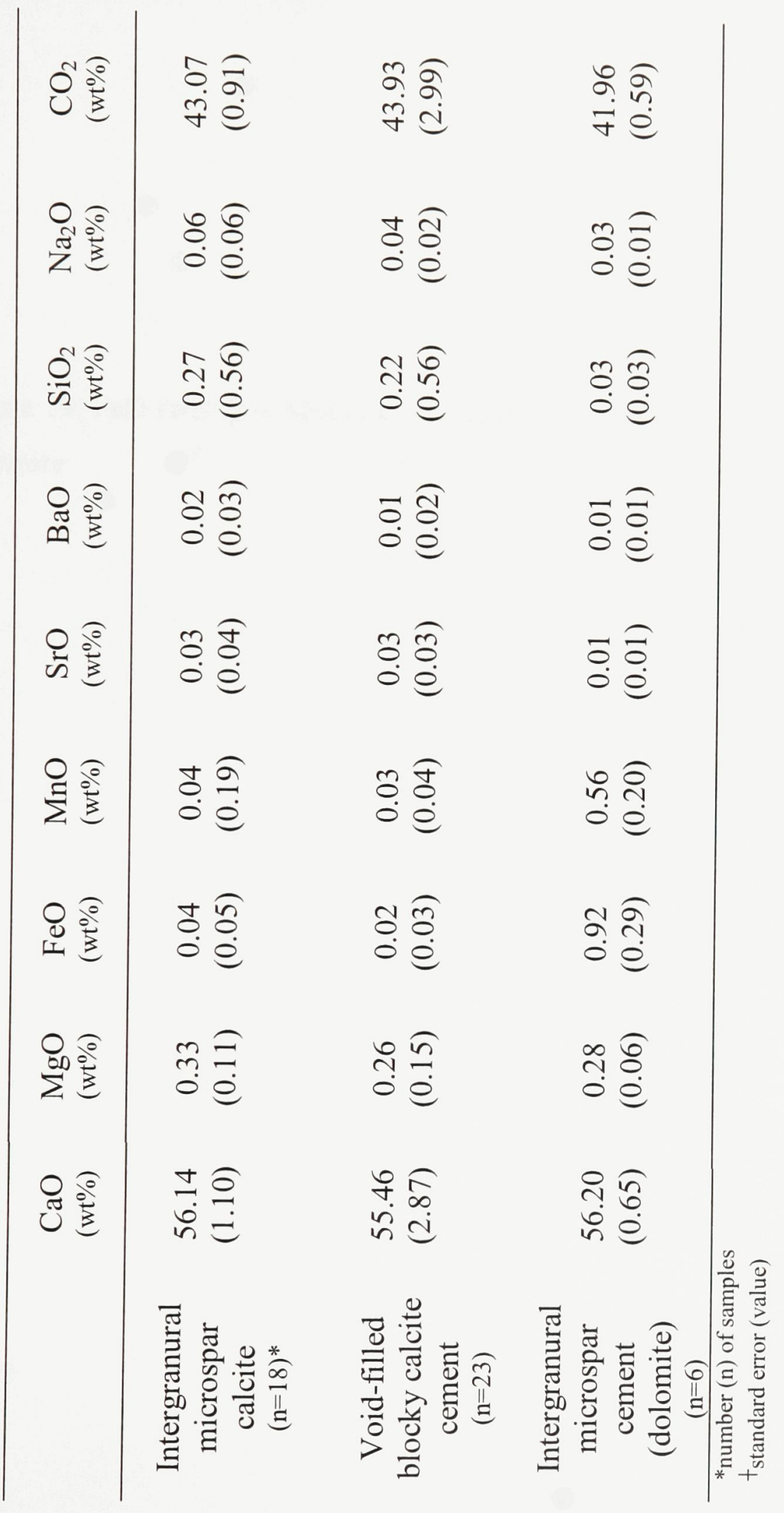


Page Facing 49

Figure 19. FeO (wt $\%)$ vs $\mathrm{MnO}(\mathrm{wt} \%)$ values of cores and rims for different types of dolomite 


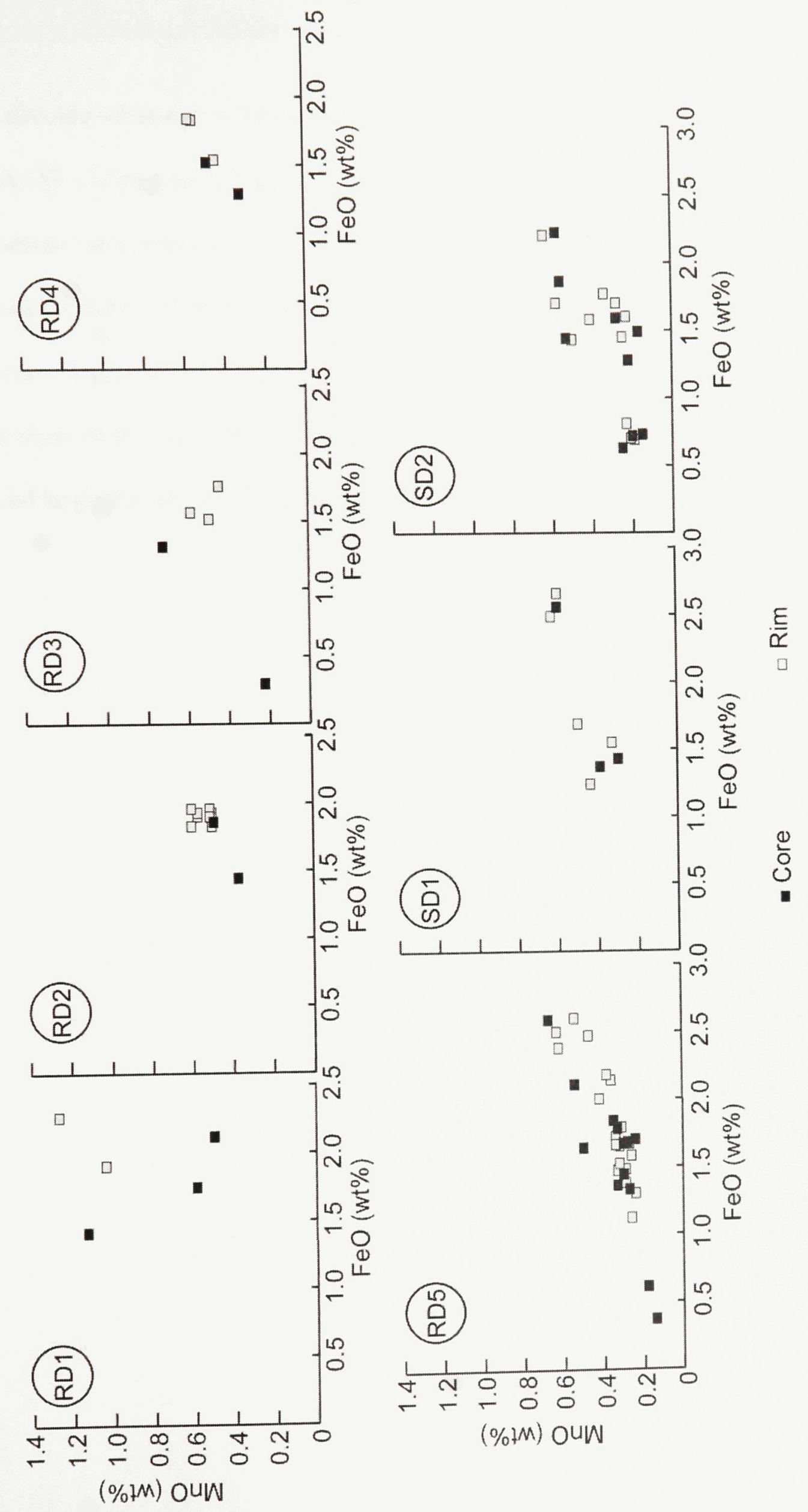




\section{Rare Earth Elements (REE)}

REE data are tabulated in Table 8 normalized to Post-Archean Average Australian Shale (PAAS) and plotted in Figure 20. Some REE are not reported because their concentrations were below detection limit. Overall, the rocks in the area show a weak negative slope that overlaps the expected values of Phanerozoic marine carbonate and phosphorites (Figure 20). Dolostone and fracture/void filling saddle dolomite patterns resemble those of the original limestone rock. This suggests that the rare earth elements are derived largely from recycling elements of pre-existing limestone. 
Page Facing 51

Table 8. Rare Earth Elements for different samples from the study area 


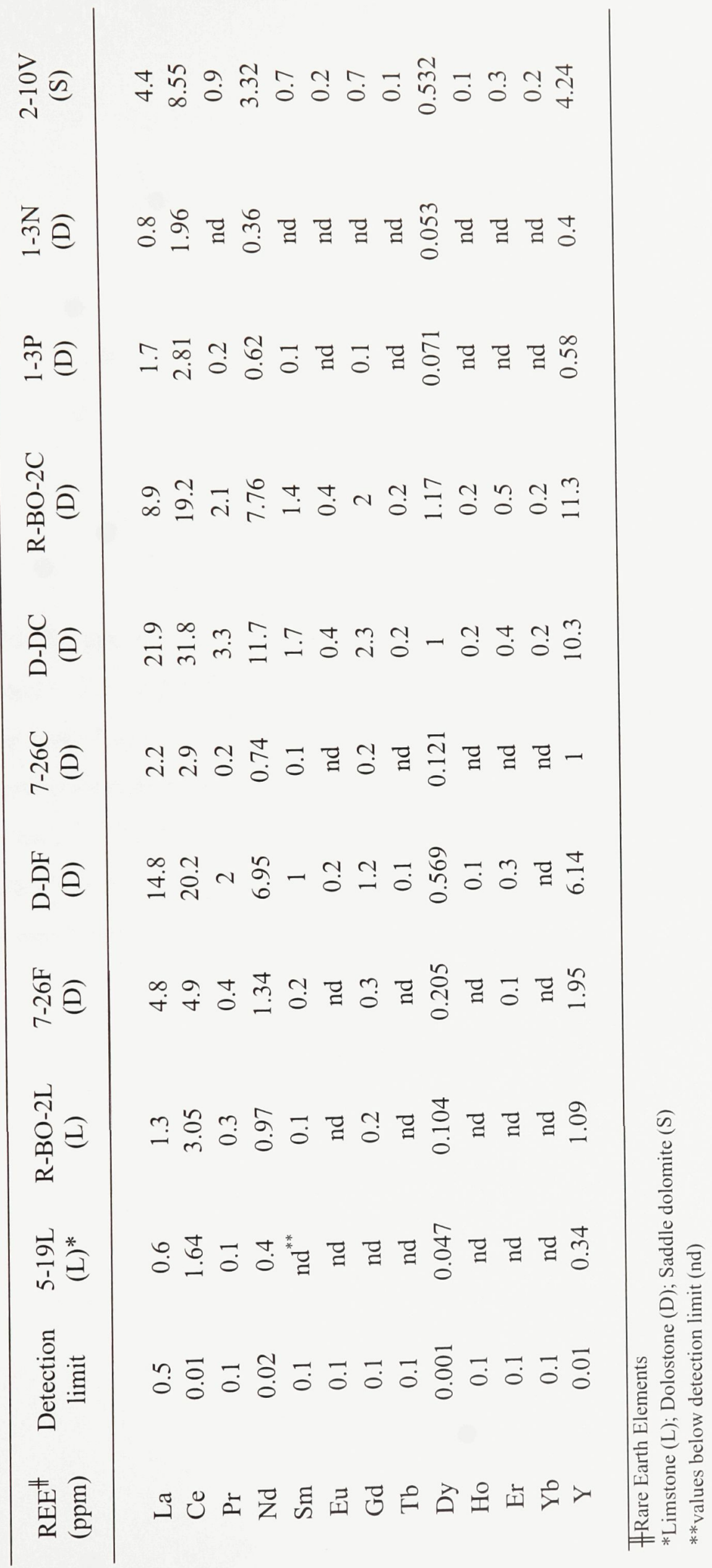


Figure 20. Samples of Locality 1 and 2 limestone, dolostone and saddle dolomite normalized to Post-Archean Average Australian Shale (PAAS: McLennan, 1989, with additions from Taylor and McLennan, 1985) compared to Phanerozoic marine and phosphoritic sources (Shields and Webb, 2004). Sources: 1 - Oligocene-Miocene phosphorite; 2 - Ottawa Valley, saddle dolomite (this study); 3 - Permian limestone; 4 - Ottawa Valley limestone (this study); 5 - Devonian microbialite; 6 - Ottawa Valley, replacement dolomite (this study). 


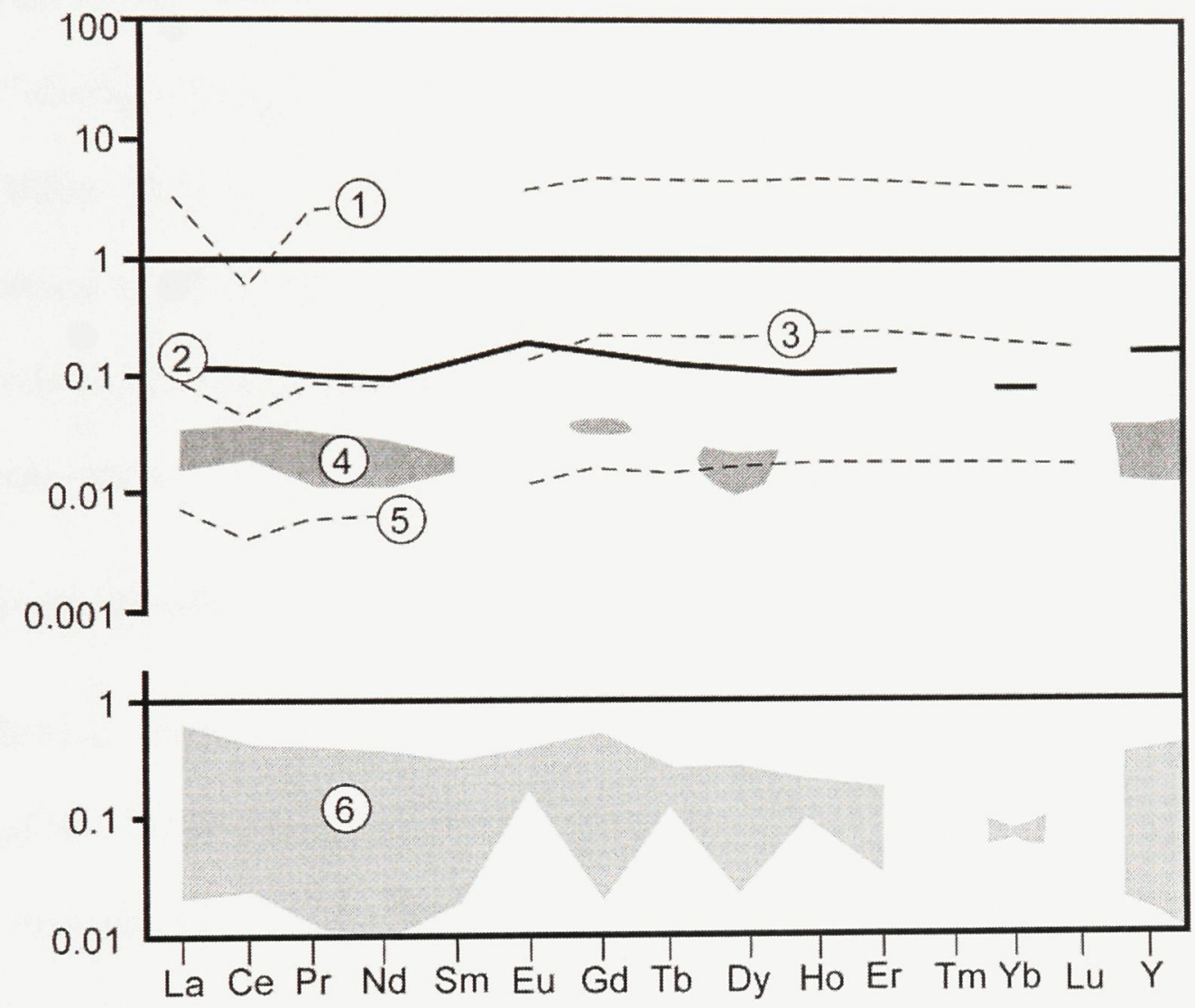




\section{DISCUSSION}

Hydrothermal diagenesis occurs when fluids are introduced to a given formation at a temperature that exceeds the ambient burial temperature of that formation (White, 1957; Machel and Lonee, 2002; Davies, 2004). It identifies a geothermal anomaly, and requires a mechanism and conduit for fluid movement. Where the geometry and orientation of the zone of alteration cross-cuts host stratigraphy, faulting and/or fracturing form the driving force (White, 1957; Davies and Smith, 2006). Data from structural, petrographical, geochemical analysis of the replacement and saddle dolomite at localities 1 and 2 support a hydrothermal origin for dolomitization of limestone within the Eganville-Douglas Paleozoic outlier.

\section{Structural style}

Paleozoic strata in the Douglas-Eganville outlier gently dip northward toward a regional WNW-ESE striking fault along the northern border of the outlier (Kay, 1942), where runs parallel to or controls the location of the Bonnechere River (Lumbers and Vertolli, 1980; Figure 4). This is demonstrated on a smaller scale within the quarry at Locality 1 where a pronounced change in dip, from gently southward dipping to northward dipping, occurs within one of the major dolostone bodies (Figure 7A). The zones of dolomitization, and faults/fractures that lie within some of these zones are oriented parallel to the interpreted regional fault where it runs to the north of the quarry, but are at an oblique $\left(32^{\circ}\right)$ angle to the same regional fault trace where it has changed direction east of the quarry (Figure 6). 
The gentle anticlinal structure coupled with orientation of strike-slip and normal fault, and dolomite zones can be explained within the context of local geological components created during movement along a left-lateral wrench system (Figure 21A, Wilcox et al., 1973), where strike of the master fault is oriented at approximately $\sim 140^{\circ}$, roughly coincident with the WNW-ESE striking regional fault that likely controls the orientation of the Bonnechere River. Related smaller scale structures develop in response to regional shear zones of extension, convergence, and strike-slip (Figure 21A). Generally, regional convergent strike-slip faults develop many reverse faults and en echelon folds that are primary cause of upward splaying flower structures (Figure 21B) in these structural systems as a result of net shortening (Allen and Allen, 2005). It would be overly speculative to interpret structure and geometry of the quarry as a positive flower structure based only on one strike-slip fault and the gentle anticlinal structure observed in outcrop. More faults are required and these, if present, are not exposed within the quarry. 
Figure 21. A) Structures associated with left-lateral fault movement shown on strain ellipse (modified after Wilcox et al., 1973). Strike of the master fault was oriented at approximately $\sim 140^{\circ}$. B) Upward splaying (positive) flower structure developed along the left-lateral fault movement (Figure from Wikimedia Commons, see http://en.wikipedia.org/wiki/Strike-slip_tectonics). 


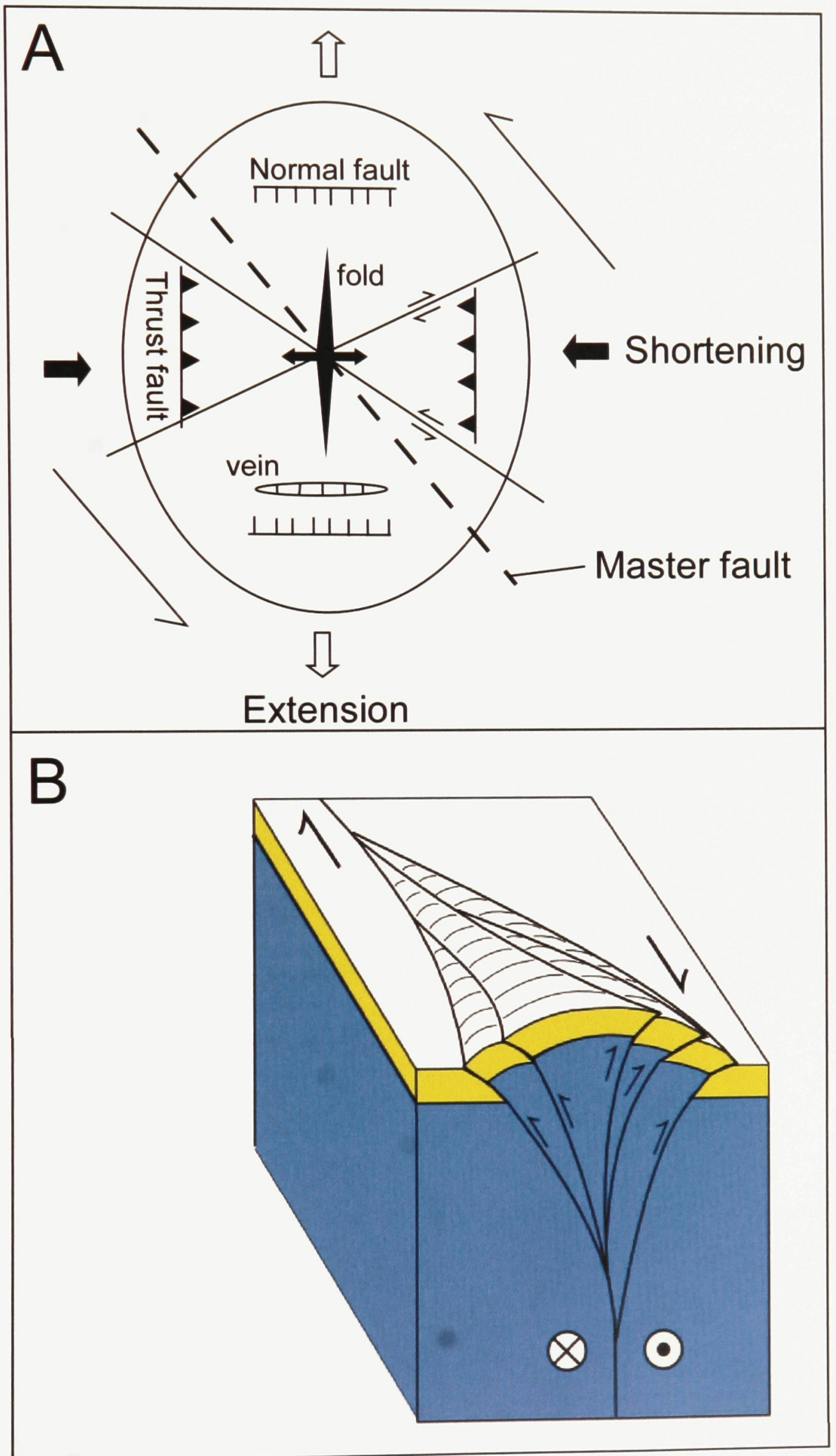




\section{Fault-related dolomitization}

Orientation of the dolomitization zones in the quarry is approximately $\sim 110^{\circ}$ (Figure 6). When placed in context of a wrench fault system (Figure 21A), zones of dolomitization occur along predicted sites of extension. It is postulated that hydrothermal fluids rose along these sites of extension, through first a series of fractures (now hidden by replacement dolomitization), flowed out laterally into the permeable limestone of the Hull Formation, and produced replacement dolomite (RD1-5) zones in the area (Figure 22).

Replacement dolomitization was followed by further development of strike-slip fault movement along which saddle dolomite (SD1 and 2) precipitated (Figure 22). Such alteration only occurs where there is evidence of faulting, and does not occur away from these structural zones. Regionally, the local presence of dolomite in water wells (Figure 5) appears to be spatially allied with faults or areas of fault intersection. Brecciation of pre-existing dolostone accompanied by white dolomite veins along a local strike-slip fault offers evidence for precipitation of dolomite due to fluid movement along a fault (Smith, 2006), and also demonstrates an evolution in the structural development from extension to horizontal components of movement. 
Page Facing 57

Figure 22. Schematic fault-related hydrothermal dolomitization model for study area: LSlimestone. RD-replacement dolomite. SD- saddle dolomite. BR-basement rocks. 


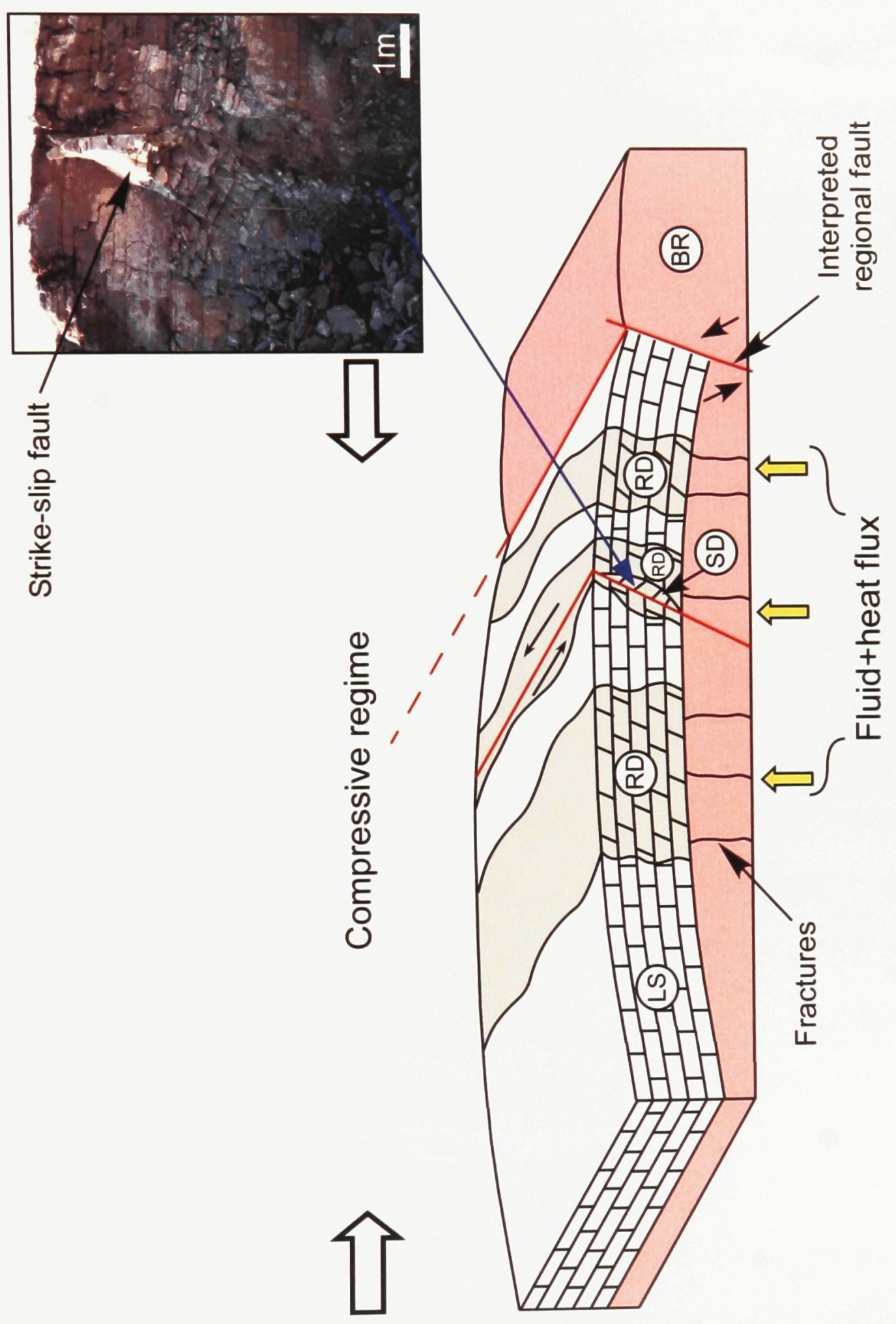




\section{Hydrothermal Conditions versus Burial Heat}

Comparison of fluid-inclusion homogenization temperatures $\left(\mathrm{T}_{\mathrm{H}}\right)$ in dolomites and maximum burial and thermal temperature of the host formation (based on conodont alteration indices; Legall et al., 1981) support a hydrothermal origin for dolomitization.

Conodont alteration indices (CAI) for eastern Ontario (Legall et al., 1981) reveal a progressive rise (from 1 to 3 ) moving southeastward along the Ottawa Valley from the Pembroke, ON, region, with the largest gradient positioned between Arnprior and Ottawa (Legall et al., 1981; Dix and Jolicoeur, 2011). Sample sites within the Paleozoic outliers west of Arnprior show that strata in the Eganville and Douglas areas have CAI values of 2 in Upper Ordovician rocks, representing assumed burial temperatures likely no greater than $\sim 80^{\circ} \mathrm{C}$ (Legall et al., 1981). Late stage void-filling calcite in a limestone sample (71(L2-F2), Appendix I) has an estimated temperature matching this burial-derived temperature (Figure 17). One locality along the Ottawa-Bonnechere River at Douglas has CAI values of 3, however. Subsurface well data (Figure 5) show that in this latter area, there is also an anomalous occurrence of dolostone, possibly along a structural zone similar to that exposed at Locality 1. The estimated CAI-based temperature for this site is $120^{\circ} \mathrm{C}$ (Legall et al., 1981) also similar to dolomite at Locality 1 . Thus, the anomalous elevated CAI value may be due to hydrothermal heating, and not regional burial.

The fluid-inclusion homogenization temperatures for dolomite from the Locality 1 and Locality 2 range from 87.2 to $115^{\circ} \mathrm{C}$ between the estimated temperatures for CAI values of 2 and 3. Thus, based on regional CAI trends, the dolomitic zones at Localities 1 
and 2 appear to identify the requirement for slightly higher temperature, maybe by $10-20^{\circ} \mathrm{C}$.

\section{Basin brines as fluid source}

No melt temperature or salinity data were acquired due to absence of inclusion freezing. However, a sense of elemental composition of fluid inclusions was determined qualitatively through artificial decrepitation (see above). The presence of $\mathrm{Ca}, \mathrm{Mg}, \mathrm{F}, \mathrm{K}$, $\mathrm{Na}$, and $\mathrm{Cl}$ and absence of evidence of sulphate in fluid inclusions suggests that neither seawater nor dissolved gypsum or anhydrite was the direct source of fluids. Fluorine, in absence of an evaporitic source, usually identifies an upper crustal source (Hodge, 1986; Warren, 1999).

The data are interpreted, therefore, to identify a predominantly $\mathrm{Ca}-\mathrm{Mg}-\mathrm{Cl}$ brine system. Many modern active continental rift and strike-slip basins show upward-driven fluids rich in $\mathrm{CaCl}_{2}$ and poor in sulphate (Hardie, 1990). Similar highly concentrated $\mathrm{CaCl}_{2}$ brines occur in the Michigan basin (Wilson and Long, 1992) and in western Canada sedimentary basin (Spencer, 1987), and are considered sources of hydrothermal dolomite (Davies and Smith, 2006).

\section{Geochemical evidence for hydrothermal alteration}

$\delta^{18} \mathrm{O}$ values for replacement dolomite (RD3-5) and saddle dolomite (SD1-2) are negative compared to the estimated composition for Upper Ordovician shallow-water marine dolomite (Figure 15) based on data for Upper Ordovician $\delta^{18} \mathrm{O}_{\text {seawater }}$ and contemporary surface temperatures (Shields et al, 2003; Came et al, 2007). Both higher temperatures accompanying burial, and mixing of meteoric diagenetic fluids with marine- 
derived fluids, will shift $\delta^{18} \mathrm{O}$ values toward more negative values (Tucker and Wright, 1990). Temperature of the host formation can be determined by plotting fluid inclusion homogenization temperatures versus $\delta^{18} \mathrm{O}_{\mathrm{dol}}$ (Figure 23). The estimated fluid composition ranges from $-0.9 \%$ to $-2.1 \% \mathrm{SMOW}$, with an average of $-1.6 \% \mathrm{SMOW}$, within the range of temperature from 97.4 to $107.5{ }^{\circ} \mathrm{C}$ (Figure 23). According to Shields and others (2003), $\delta^{18} \mathrm{O}_{\text {seawater }}$ values for the Late Ordovician were likely $-3 \%$ to $-4 \%$ SMOW. Thus, $\delta^{18} \mathrm{O}_{\text {fluid }}$ values from this study (-0.9 to $-2.1 \%$ ) are more positive, which indicates that replacement dolomite and saddle dolomite from Locality 1 and Locality 2 were not marine or slightly marine-derived fluids. They require a source substantially altered from an original marine origin.

For comparison, Upper Ordovician platform carbonates in central New York have $\delta^{18} \mathrm{O}$ limestone values (relative to VPDB) of about $-6.5 \%$, and more negative $\delta^{18} \mathrm{O}$ values (-9 to $-12.5 \%$ ) for matrix dolomite and saddle dolomite (Figure 15$)$. These hydrothermal dolomites identify a fluid composition of $+2 \%$ SMOW (Figure 23; Smith, 2006), much more evaporated relative to the Eganville-Douglas outlier region. This suggests that replacement dolomite and saddle dolomite from the Ottawa Valley outliers are derived from cooler fluids of similar composition, or derived from less evaporated source fluids. It raises the question of whether there was a regional compositional fluid gradient west out of the Appalachian orogen (see below), or it might reflect greater mixing with less saline (seawater, meteoric) fluids compared to the more paleoseaward basinal strata in New York. 
Figure 23. Fluid inclusion homogenization temperature $\left(\mathrm{T}^{0} \mathrm{C}\right)$ vs. $\delta^{18} \mathrm{O}_{\text {diagenetic fluid }}$ for $\delta^{18} \mathrm{O}_{\text {dolomite }}$ values that were calculated from the equation $10^{3} \ln \alpha=3.2 \times 10^{2} \mathrm{~T}^{-2}-3.3$ (Land, 1983). a) Saddle dolomite values from this study. b) Matrix and saddle dolomite values from Trenton-Black River in New York State (Smith, 2006). 


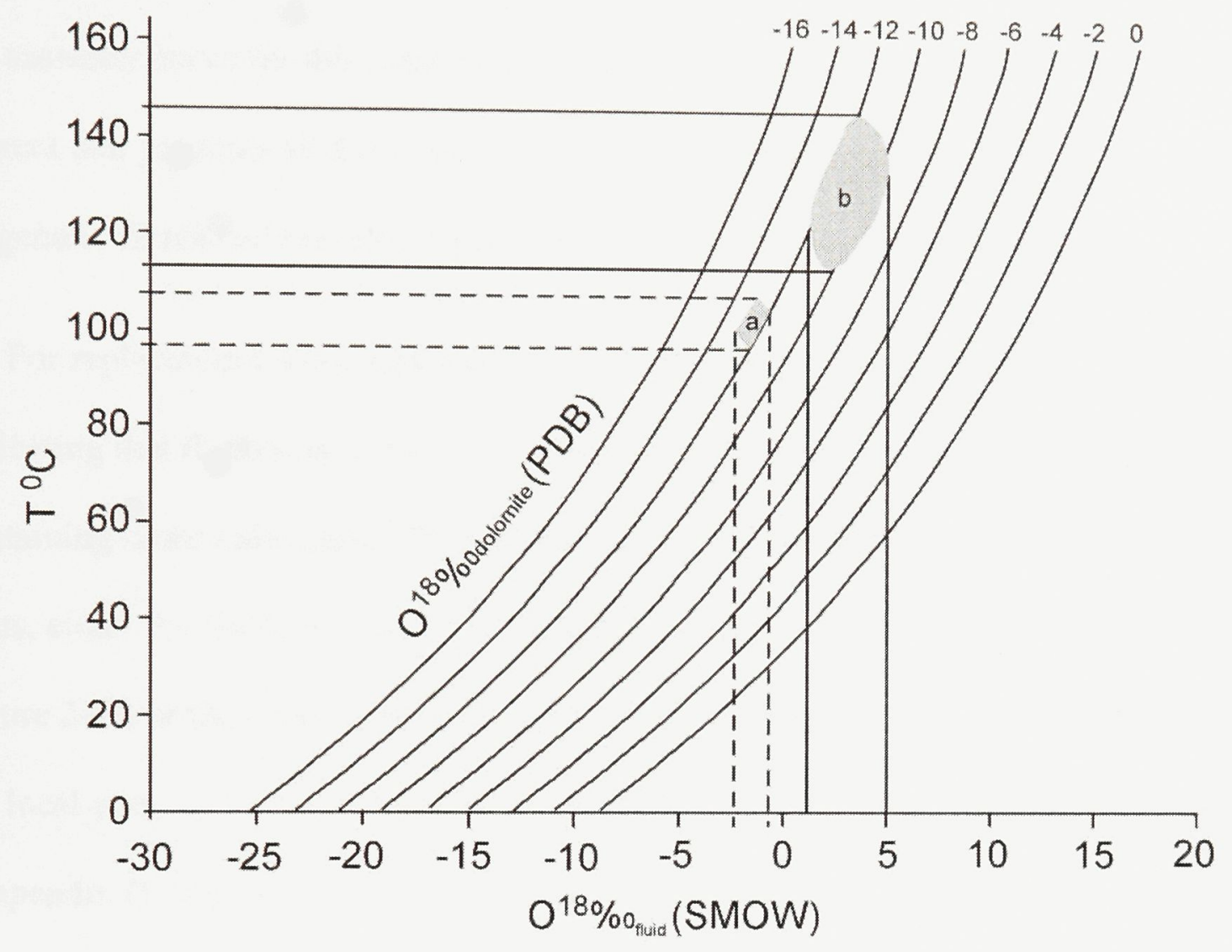


Another geochemical perspective is offered by the ${ }^{87} \mathrm{Sr} /{ }^{86} \mathrm{Sr}$ ratios when compared to Phanerozoic seawater. For Late Ordovician seawater, the ratio lies between 0.7078 and 0.7080 (McArthur at el. 2001). Limestone samples from Locality 1 and Locality 2 fit on the seawater curve for this time period (Figure 24A) suggesting that late stage calcite cement that predates all dolomite types was derived either from a modified seawater, or diagenetic fluids had recycled Upper Ordovician limestone during diagenesis.

For replacement dolomites RD3-5, ${ }^{87} \mathrm{Sr}{ }^{86} \mathrm{Sr}$ values plot above the seawater curve indicating that the fluids from which they precipitated had interacted with strata containing more radiogenic ${ }^{87} \mathrm{Sr}$ than defined by Late Ordovician seawater (Figure 24B). Thus, either the fluids reflect the influence of younger seawater (e.g., Silurian, Devonian; Figure 24B) or they represent basin-derived fluids. Dolomitic and calcitic marbles from the local area can be excluded, because with values of 0.7056 and 0.7052 , respectively (Appendix I), similar to the general range of Precambrian marbles cited by Veizer and Compston (1976), they are too low to account for the radiogenic Sr in the dolostones. From the Frontenac Arch, Krogh and Hurley (1968) reported values from Precambrian gneiss of 0.7260 . The character of basement and potential Phanerozoic strata that lies beneath the quarry floor remains unknown. It is possible that basin-derived brines had interacted with similar radiogenic sources.

${ }^{87} \mathrm{Sr} /{ }^{86} \mathrm{Sr}$ values for SD1 saddle dolomite are interesting because they overlap Late Ordovician seawater values (Figure 24C). Due to the fact that this dolomite clearly postdates earlier dolomite and the limestone, one must also consider recycling ${ }^{87} \mathrm{Sr}$ from host rock limestone that possess a similar composition as illustrated in Figure 24C. 
Figure $24 .{ }^{87} \mathrm{Sr} /{ }^{86} \mathrm{Sr}$ isotope values from Locality 1 and Locality 2 plotted in comparison to seawater ${ }^{87} \mathrm{Sr} /{ }^{86} \mathrm{Sr}$ isotope values from McArthur at el. (2001). A) Limestone.

B) Replacement dolomite. C) Saddle dolomite. 


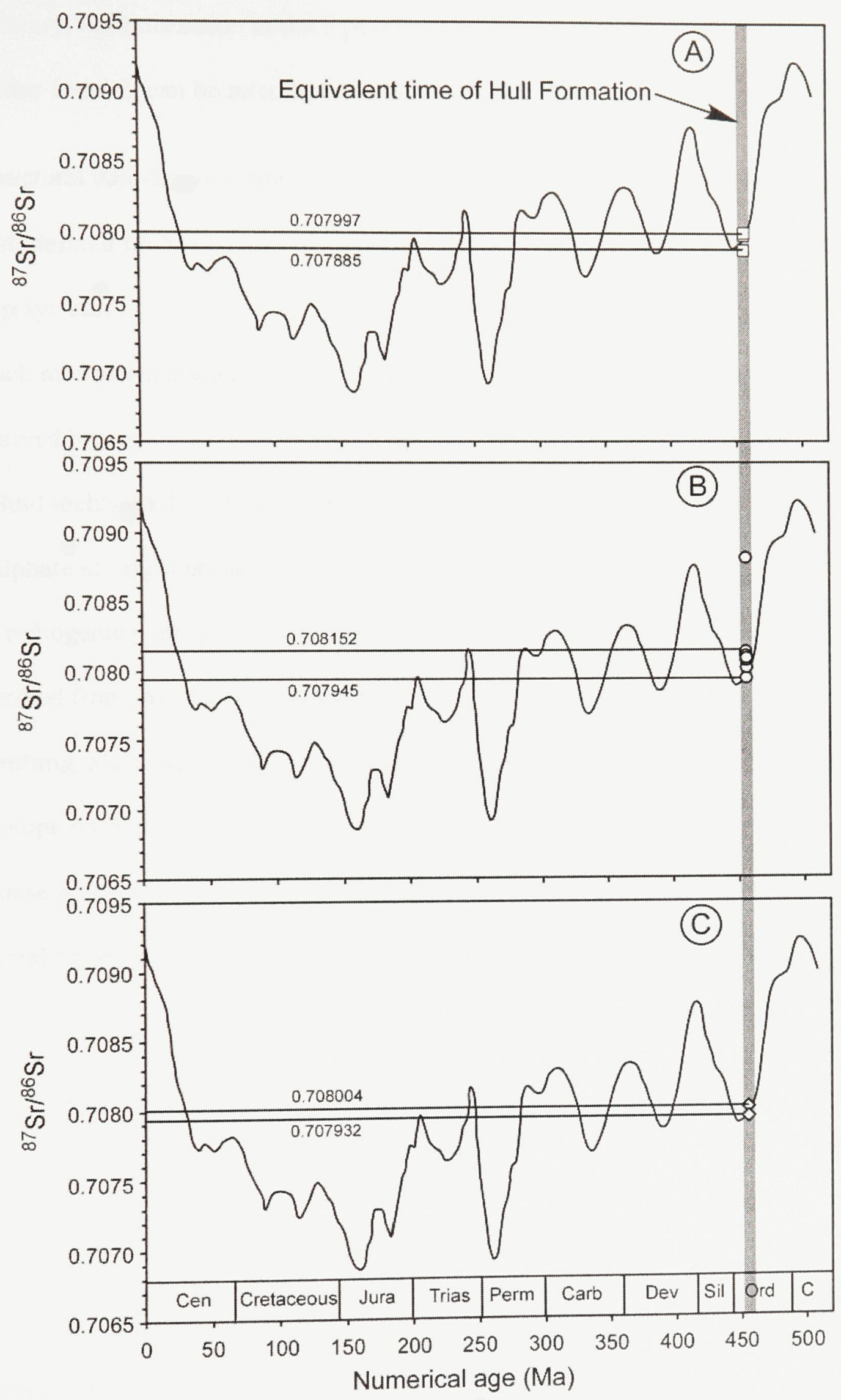


In summary, dolomitization in the Eganville-Douglas outlier, based on exposure at

Localities 1 and 2, can be interpreted as follows (see Figure 22):

1. Structural data demonstrates that dolomitization followed incipient flexuring, then well defined fault/fracture systems generated in concert with a likely master strikeslip system;

2. Such movement allowed and promoted vertical and oblique movement of basinderived brines;

3. Fluid inclusion data demonstrate that hot $\left(87.2-115^{\circ} \mathrm{C}\right)$ brines of $\mathrm{Ca}-\mathrm{Mg}-\mathrm{Cl}$, and not sulphate in origin promoted dolomitization;

4. A radiogenic source of $\mathrm{Sr}$ was involved in replacement dolomitization, possibly derived from Precambrian rocks;

5. Faulting, allowing the production of saddle dolomite, involved a reduction in the Srisotope ratios indicating, possibly, recycling of limestone (e.g., dissolution);

6. These processes identify a hydrothermal system $10-20^{\circ} \mathrm{C}$ hotter relative to ambient burial temperatures, driven by developing strike-slip tectonism; 


\section{Timing and Depth of Dolomitization}

Timing and depth of burial during hydrothermal alteration in Localities 1 and 2 require assessment of overburden thickness, assumed geothermal gradients and estimates of the average surface temperature at the time of deposition. The geological framework of two hypotheses are presented, then each is examined in terms of hydrothermal temperatures and the implications these have on geothermal gradients.

The first hypothesis identifies hydrothermal alteration as a Late Ordovician event related to culmination of Taconic orogenesis. This period of convergent tectonism caused northwestward migration of the Appalachian structural front in the Late Ordovician (Easton, 1992), which would have resulted in development of an impactogen (Sengor et al., 1978) wherein the NE-SW oriented faults (in present-day coordinates) of the Taconic orogeny would have to cross-cut the older E-W and WNW-ESE faults of Neopterozoic age associated with initiation of the Ottawa Bonnechere graben (Rimondo and Benn, 2005). The structural result of such a collisional system would be to transform the once normal faults of Precambrian age into Late Ordovician strike-slip faults. In addition, this structural activity would form a mechanism to drive regional fluid flow from the orogen toward the craton interior (Kesler, 1996), both along and up along faults. During this period of time, the total overburden thickness in the Ottawa region from the top of the Hull Formation to the base of Silurian was likely no thicker than $\sim 650 \mathrm{~m}$ (based on Williams, 1991; Sanford, 1993),

The second hypothesis is that hydrothermal dolomitization may have occurred during the Late Devonian related to the Acadian orogenesis. This was a period of widespread 
deformation and fluid migration (Kesler, 1996). Silurian and Devonian strata are not preserved in eastern Ontario, and an estimation of their thickness is very speculative. According to Legall et. al., (1981), approximate total thickness of the Silurian and Devonian strata removed from the region would be no more than 400-500 m. By using the approximately estimated thickness of $650 \mathrm{~m}$ given by Sanford (1993) from the top of the Hull Formation to the base of Silurian, and additional Silurian and Devonian thickness of 400-500 m, the total of overburden removed from the area would be over $1150 \mathrm{~m}$ or $\sim 1 \mathrm{~km}$.

The implication of each hypothesis with regard to geothermal gradients can be assessed using fluid inclusion data. Fluid inclusion homogenization temperatures of the host limestone at Locality 1 , in combination with CAI alteration indices, suggest burial temperatures likely to be around $\sim 80^{\circ} \mathrm{C}$. During the Ordovician and Devonian, the region lay within the subtropics. Thus, using a surface temperature of $25^{\circ} \mathrm{C}$, the maximum burial temperature during culmination of limestone genesis was $65^{\circ} \mathrm{C}$. In order, to accommodate this burial temperature, a geothermal gradient would have been approximately $\sim 100^{\circ} \mathrm{C} / \mathrm{km}$, if hydrothermal dolomitization occurred during the Late Ordovician when overburden thickness was no more than $650 \mathrm{~m}$. If hydrothermal dolomitization occurred during the Late Devonian, when overburden thickness was $>1 \mathrm{~km}$, the geothermal gradient was about half, $\sim 56^{\circ} \mathrm{C} / \mathrm{km}$. It needs to be stated that estimates of overburden are very poorly constrained, thus these values are upper limits on potential geothermal gradient ranges.

Generally, a typical geothermal gradient for cratonic basins is between $20^{\circ}$ to $25^{\circ} \mathrm{C} / \mathrm{km}$ (Klemme, 1975), and this value was used by Legall et al. (1981) to assess the 
burial patterns of CAI values along the graben. However, the region is not a typical cratonic basin; it originated as a graben, and was subject to, at least, local reactivation during the Middle Ordovician during onset of Taconic orogenesis (Dix and Al Rodhan, 2006), then again during foundering of the Ottawa Group platform (Dix and Jolicoeur, 2011). In comparison, strike-slip basins can have very high (up to $200^{\circ} \mathrm{C} / \mathrm{km}$ ) geothermal gradients (Allen and Allen, 2005).

A seismic refraction survey across the graben showed that the MOHO has a step-like geometry beneath the axis of the graben, that mantle material may have disrupted the geometry of the MOHO beneath the graben, and a mantle-crust offset across this profile may identify deep-seated faults (Mereu et al., 1986). Thus, heat flow may have been more elevated than previous studies (e.g., Legall et al., 1981) have considered.

Based on the data presented here, I consider the second hypothesis to be the more reasonable solution, because the clear step-like change in the Moho beneath the graben leaves little doubt that the graben is a deep-seated structure of major tectonic significance (Mereu et al., 1986). Therefore, this tectonic activity may lead to an increase in subsidence rates and high $\left(\sim 56^{\circ} \mathrm{C} / \mathrm{km}\right)$ geothermal gradients. The required elevated $\left(\sim 100^{\circ} \mathrm{C} / \mathrm{km}\right)$ geothermal gradient for the Late Ordovician solution may be too unreasonable. Further work is needed to determine if hydrothermal dolomitization is related to the Late Ordovician Taconic orogenesis or simply relates to the Late Devonian Acadian orogenesis. 


\section{Comparison to other hydrothermal dolomite fields}

Hydrothermal dolomite reservoirs represent significant resource targets for petroleum and metallic minerals (e.g., some MVT deposits) in North America, and globally (Davies and Smith, 2006). Some of these targets are likely to have been ignored previously because of their common occurrence in structural lows, which are unlikely to have been drilled during earlier exploration phases (Smith, 2006). Some of the most productive fields such as the Albion-Scipio field in the Michigan basin and the Trenton-Black River field in New York State, USA share some attributes with structurally controlled hydrothermal dolomitization at Locality 1 and Locality 2.

Hydrothermal dolomites of the Upper Ordovician Trenton-Black River Group in south-central New York form around basement-rooted wrench faults (Smith, 2006). Vuggy porosity, brecciation, and occurrences of saddle dolomite are associated with elongate fault-bounded structural lows, commonly known as a negative flower structure (Figure 25). According to Smith (2006), matrix and saddle dolomite formed from high temperature $\left(110-170^{\circ} \mathrm{C}\right.$, See Table 4), high-pressure, saline, and Fe- and Mn-rich brines fluids, which flowed up through active strike-slip faults mixing with the basement rocks or immature feldspar-rich siliciclastics. Hydrothermal alteration occurred during the Late Ordovician Taconic Orogeny when the overburden thickness was less than 500m (Smith, 2006), much like alteration in Locality 1 and Locality 2 (this study). Other similarities include brecciation and occurrence of saddle dolomite.

The Albion-Scipio field in the Michigan basin is another target of hydrothermal dolomitzation in the Trenton-Black River Formations. Hydrothermal dolomitization is 
fracture-controlled and related to NW-SE fault and fold trends oriented to a regional structural trend (Figure 25, Hurley and Budros, 1990). The dolomite is coarsely crystalline, fractured, vuggy, and cavernous and contains white saddle dolomite. Host replacive dolomite and saddle dolomite have similar ${ }^{18} \mathrm{O}$ values (Table 9), much like dolomites in Locality 1 and Locality 2 (See Data, Table 3). According to Allan and Wiggins, (1993), fluid inclusion analysis indicates that dolomite precipitated from a very saline $\mathrm{Na}-\mathrm{Ca}-\mathrm{Mg}-\mathrm{Cl}$ brine. Unlike dolomitization in Locality 1 and Locality 2 where basin brines were the fluid source, mixing of Salina brine and Silurian seawater played the important role in dolomitization (Allan and Wiggins, 1993; Barnes et. al., 2008). However, a speculative model for timing of hydrothermal alteration suggests that dolomitization occurred during Appalachian orogenic events (Late Ordovician Taconic Orogeny), which led to reactivation of basement faults and migration of mixed brines with Silurian seawater (Barnes et. al., 2008).

From this comparison emerges the possibility that dolomitization in the EganvilleDouglas outlier could have been of Late Ordovician age; part of a spectrum of regional tectonism well removed from the Taconic orogeny, yet likely linked through translation of regional stress that triggered reactivation of basement faults. The comparison (Table 9) also reveals that petroleum-mineralized reservoirs are associated with structural sags (or negative flower structures) whereas Locality 1 may be part of a positive flower structure. Absence of any significant presence of sulphides, nor any petroliferous smell associated with the dolostone suggest that there never was any petroleum linked to fluid migration history. 
Page Facing 70

Table 9. General attributes of hydrothermal dolomites in North America compared to this study 


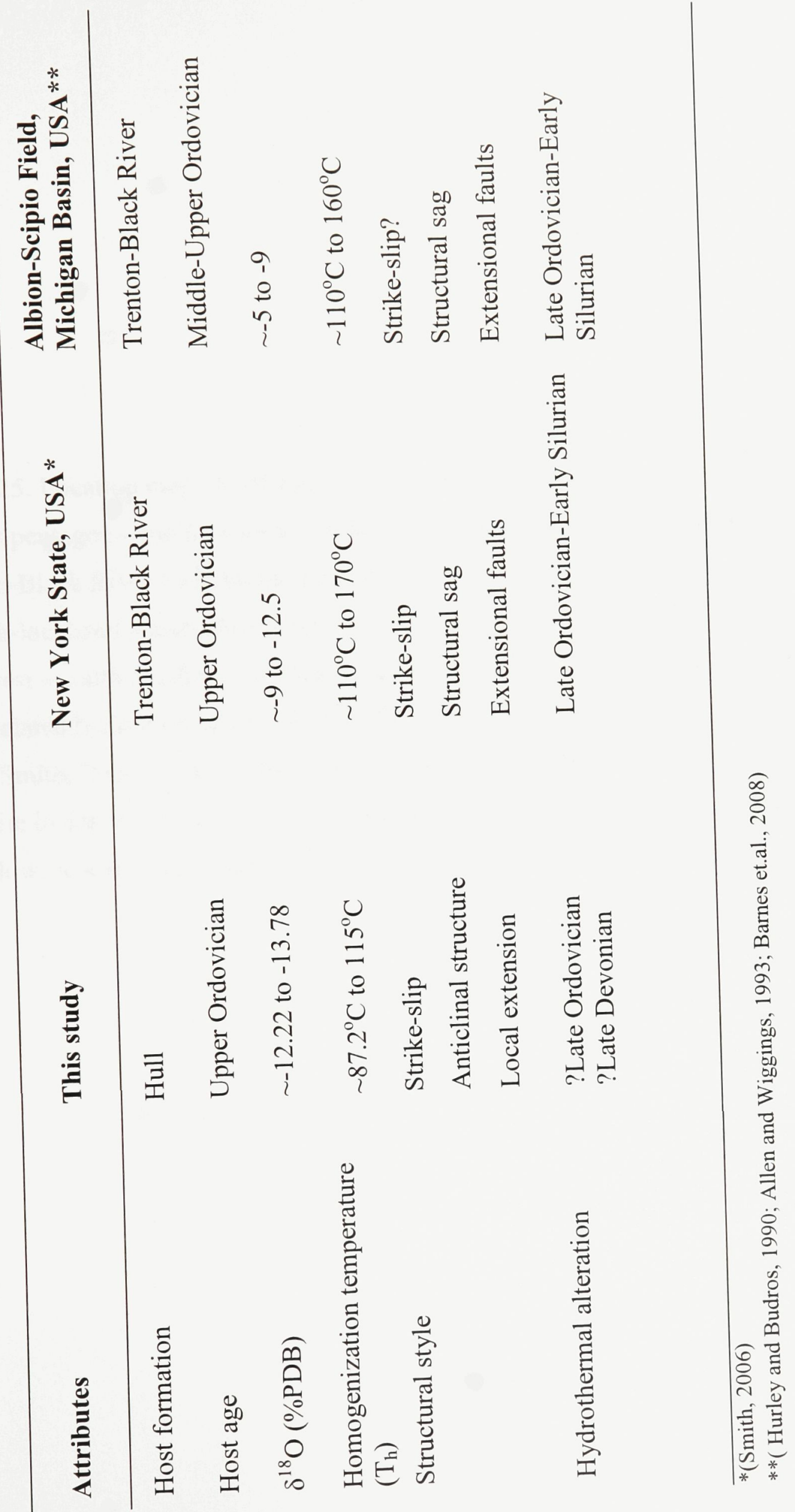


Figure 25. Location map (A) of hydrothermal dolomite fields in eastern North America (yellow pentagon - the Albion-Scipio field, Michigan Basin, USA; yellow star - the Trenton-Black River hydrothermal dolomite in New York, USA; red star - this study). B) Wrench-localized Albion-Scipio field trend in the Michigan Basin showing northnorthwest - south-southeast trending en echelon sags (thick lanes) (Budros, 2001). C) Fault-related hydrothermal alteration model for Trenton-Black River dolomite in New York (Smith, 2006). Shale is shown in shades of grey, limestone in shades of blue, dolomite in shades of pink, and sandstone in shades of yellow. Red arrow indicates hot fluid flow. A-stands for - strike-slip away, T-stands for - strike-slip toward. 

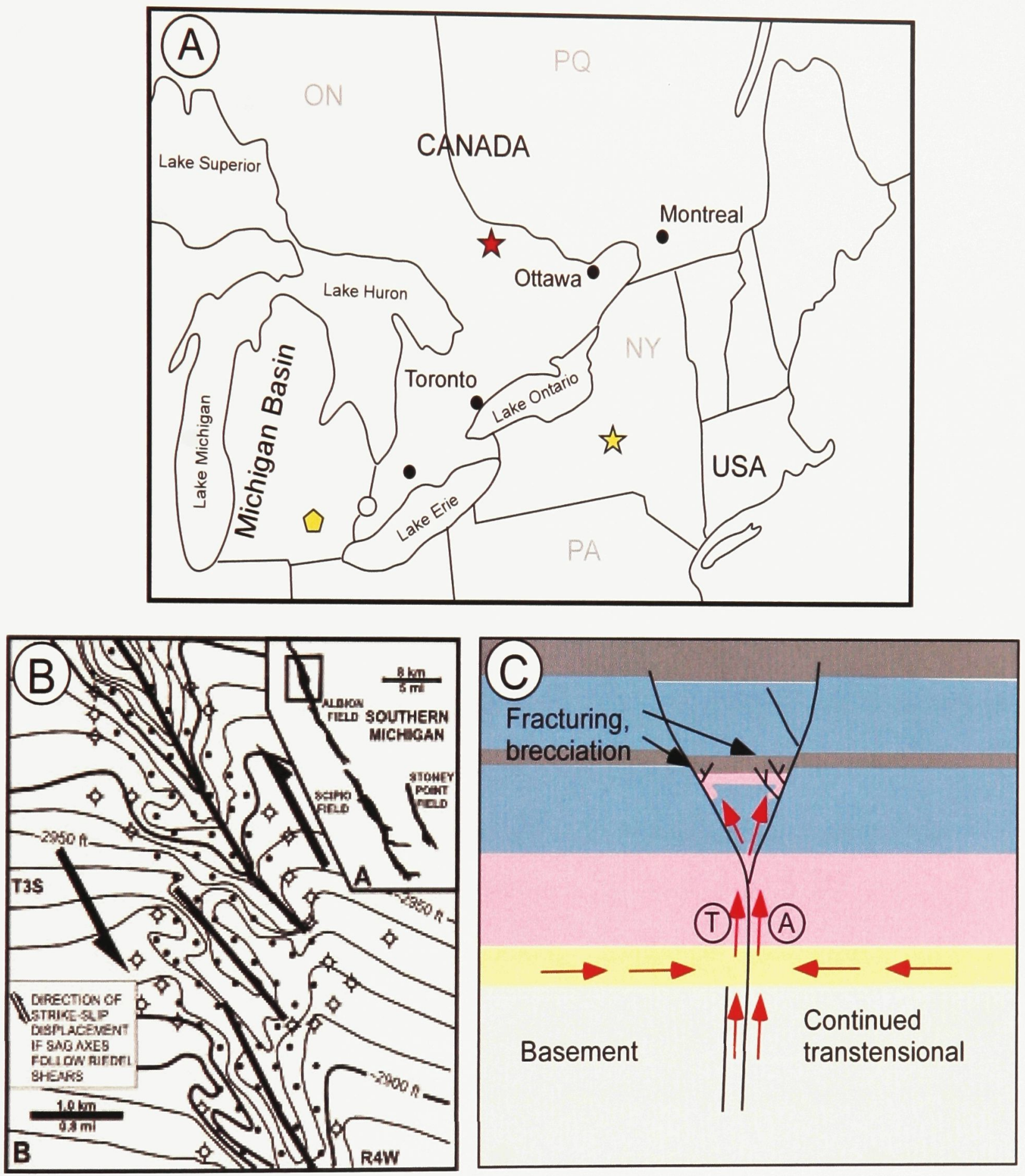


\section{CONCLUSIONS}

1. Replacement dolomite and vein-fill saddle dolomite occupy a series of relatively narrow (10s of $\mathrm{m})$ zones of alteration of Upper Ordovician limestone within a faultbound Paleozoic outlier (Eganville-Douglas) located northwest of the Ottawa Embayment within the Ottawa Valley.

2. Paragenesis of dolomite types indicate a progressive loss of a pre-existing limestone through dolomite replacement coupled with increased intercrystalline (dolomite) porosity; then fracturing/faulting and migration of fluids from which saddle dolomite precipitated.

3. Structural data demonstrates that dolomitization followed incipient and well defined fault/fracture systems that are predicted on the basis of movement of an adjacent regional strike-slip fault. This movement allowed and promoted vertical and oblique movement of basin-derived brines through the subsurface.

4. Fluid inclusion data in combination with oxygen isotope data demonstrate that hydrothermal fluids were hot $\left(87.2-115^{\circ} \mathrm{C}\right)$ brines of $\mathrm{Ca}-\mathrm{Mg}-\mathrm{Cl}$ origin, and not sulphate based. These fluids were $10-20^{\circ} \mathrm{C}$ hotter than ambient burial heat, as defined by prior conodont alteration indices (Legall et al., 1981). A source of Sr in dolomitization was more radiogenic than the host limestone and marble that occurs in the area. Potential sources are siliciclastics, if they underlay the limestone in the outlier, or Precambrian gneissic rocks.

5. Hydrothermal alteration was associated with regional orogenic episodes driving basement fault reactivation deep within the craton. This could have occurred either during the Late Ordovician, related to culmination of Taconic orogenesis, when the 
host limestone was buried to a depth of only $\sim 650 \mathrm{~m}$. However, this requires very high $\left(\sim 100^{\circ} \mathrm{C} / \mathrm{km}\right)$ geothermal gradients. Alternatively it could have occurred during Late Devonian and related to the Acadian orogenesis, when the overburden thickness was $1150 \mathrm{~m}$, and a geothermal gradient of $\sim 56^{\circ} \mathrm{C} / \mathrm{km}$. These represent maximum thermal limits given that the amount of overburden is poorly known.

6. Comparison with the Albion-Scipio field in the Michigan basin and hydrothermal dolomitization in the Trenton-Black River succession of New York State, USA suggest that brecciation, occurrence of saddle dolomite and porosity is associated with wrench faults. Furthermore, hydrothermal alteration in Locality 1 and Locality 2 may have occurred during the Late Ordovician Taconic Orogenesis, much like alteration in Albion-Scipio and Trenton-Black River fields. However, evaporates were not the direct source of fluids for dolomitization in Locality 1 and Locality 2 , unlike mixing of Saline brines and Silurian seawater in Albion-Scipio field. 


\section{REFERENCES}

Allan, J.R. and Wiggins, W.D. 1993. Dolomite reservoirs: Geochemical techniques for evaluating origin and distribution. American Association of Petroleum Geologists, Continuing Education Course Notes 36, p.129.

Allen, P.A. and Allen J.R. 2005. Basin analysis: principles and applications. Second edition, p. 203.

Barnes, D.A., Parris, T.M., Grammer, G.M. 2008. Hydrothermal dolomitization of fluid reservoirs in the Michigan Basin, USA. American Association of Petroleum Geologists, Annual Convention, Asbtract.

Baumagartner, M. And Bakker, R.J. 2008. $\mathrm{CaCl}_{2}$-hydrate nucleation in synthetic fluid inclusions. Chemical Geology, v. 265, p. 335-344.

Bleeker, W., Dix, G.R., Davidson, A., LeCheminant, A. 2011. Tectonic evolution and sedimentary record of the Ottawa-Bonnechere graben: Examing the Precambrian and Phanerozoic history of magmatic activity, faulting, and sedimentation; Geological Association of Canada - Mineralogical Association of Canada - Society of Economic Geologists - Society for Geology Applied to Mineral Deposits Joint Annual Meeting, Ottawa 2011, Guidebook to Field Trip 1A, p.98.

Brass, G.W. 1980. Stability of brines on Mars. Icarus, v. 42, p. 20-28.

Brett, C. E. and Baird, G. C. 2002. Revised stratigraphy of the Trenton Group in the type area, central New York State: sedimentology, and tectonics of a Middle Ordovician shelf-to-basin succession. In: Taconic Convergence: Orogen, Foreland Basin and 
Craton. C.E. Mitchell and R. Jacobi (eds.). Physics and Chemistry of the Earth, v. 27, p. 231-263.

Burke, K. and Dewey, J.F. 1973. An outline of Precambrian plate development. In: Implications of Continental Drift to the Earth Sciences. D.M. Tarling and S.K. Runcorn (eds.). Academic Press, v. 2, p. 1035-1046.

Came, R.E., Eiler, J.M., Veizer, J. Azmy, K. Brand, U. And Weidman, C.R. 2007. Coupling of surface temperatures and atmospheric $\mathrm{CO}_{2}$ during the Paleozoic era. Nature, v. 449, p. 198-201.

Carignan, J. Gariepy, C. Hillaire-Marcel, C. 1997. Hydrothermal fluids during Mesozoic reactivation of the St. Lawrence rift system, Canada. $\mathrm{C}, \mathrm{O}, \mathrm{Sr}$, and $\mathrm{Pb}$ isotopic characterization. Chemical Geology, v. 137, p. 1-21.

Davies, G. R. 2004. Hydrothermal (thermobaric) dolomite and leached limestone reservoirs: General principles, genetic connections and economic significance in Canada (abs.): AAPG Annual Meeting Program, v. 13, p. A32.

Davies, G.R. and Smith, L.B. Jr. 2006. Structurally controlled hydrothermal dolomite reservoir facies: An overview. American Association of Petroleum Geologists, Bulletin, v. 90, p. 1641-1690.

Derry, Michner, Booth and Wahl and Ontario Geological Survey. 1989. Limestone Industries of Ontario, v. II-Limestones Industries and Resources of Eastern and Northern Ontario. Ontario Ministry of Natural Resources, Land Management Branch, p. 196. 
Dix, G.R. and Al Rodhan, Z. 2006. A new geological framework for the Middle Ordovician Carillon Formation (uppermost Beekmantown Group, Ottawa Embayment): onset of Taconic foreland deposition and tectonism within the Laurentian platform interior. Canadian Journal of Earth Sciences, v. 43, p. 13671387.

Dix, G.R. and Jolicoeur, C.P. 2011. Tectonostratigraphic framework of Upper Ordovician source rocks, Ottawa Embayment (eastern Ontario). Canadian Petroleum Geology, Bulletin, v.59, p. 7-26

Dix, G.R. and Robinson, G.W. 2003. The geochemical record of hydrothermal mineralization and tectonism inboard of the Applachian Orogen: the Ottawa Embayment. Chemical Geology, v. 197, p. 29-53.

Doig, R. 1970. An alkaline province linking Europe and North America. Canadian Journal of Earth Sciences, v. 7, p. 22-28.

Dunham, R.J. 1962. Classification of carbonate rocks according to depositional texture. In: Classification of carbonate rocks. W.E.Ham (ed.). American Association of Petroleum Geologists, v.1, p. 108-121.

Easton, R.M. 1992. The Grenville province and the Proterozoic history of central and southern Ontario. In: The geology of Ontario: Toronto, Ontario. P.C. Thurstan et al., (eds.). Ministry of Northern Development and Mines, p. 715-904.

Ettensohn, F.R. 2008. The Appalachian foreland basin in eastern United States. In: The Sedimentary Basin of the United States and Canada. A.D. Miall (ed.). Amsterdam, Elsevier, p. 105-162. 
Gittins, J. MacIntyre, R.M., and York, D. 1967. The ages of carbonatites complexes in eastern Canada. Canadian Journal of Earth Sciences, v. 4, p. 651-655.

Goldstein, R.H. and Reynolds, T.J. 1994. Systematics of fluid inclusions in diagenetic minerals. Society for Sedimentary Geology, Short course, p. 31.

Hardie, L. A. 1990. The roles of rifting and hydrothermal $\mathrm{CaCl}_{2}$ brines in the origin of potash evaporites: A hypothesis. American Journal of Science, v. 290, p. 43-106.

Hodge, B.L. 1986. Occurrence and exploitation of fluorite. In: Geology in the real world. R.W.Nesbitt and I. Nichol (eds.). The Kingsley Dunham volume. Inst. Mining Metallurgy, p. 165.

Hofmann, H.J. 1972. Stratigraphy of the Montreal area. International Geological Congress, Excursion B-3.

Hurley, N.F. and Budros, R. 1990. Albion-Scipio and Stoney Point fields - U.S.A. Michigan basin. In: Stratigraphic traps I. E.A. Beaumont and N.H. Foster (eds.). American Association of Petroleum Geologists Treatise of Petroleum Geology, Atlas of Oil and Gas Fields, p. 1-37.

Kay, G.M. 1942. Ottawa-Bonnechere Graben and Lake Ontario homocline. Geological Society of American Bulletin, v. 53, p. 585-646.

Kesler, S.E. 1996. Appalachian Mississippi Valley-Type deposits: paleoaquifers and brine provinces. In: Carbonate-Hosted Lead-Zinc Deposits. Sangster (ed.). SEPM Special Publication No. 4, p. 29-57. 
Klemme, H.D. 1975. Geothermal gradients, hear flow and hydrocarbon recovery. In:

Petroleum and global tectonics. A.G. Fisher and S. Judson (eds.). Princeton University Press, p. 251-304.

Kumarapeli, P.S. 1978. The St. Lawrence paleo-rift system: A comparative study. In: Tectonics and geophysics of continental rifts. I.B. Ramberg and E.R. Neuman (eds.). New York, D. Reidel Publishing Company, p. 367-384.

Kumarapeli, P.S. 1985. Vestiges of Iapetan rifting in the craton west of the northern Appalachians. Geoscience Canada, v. 12, p. 54-59.

Land, L.S. 1983. The application of stable isotopes to studies of the origin of dolomite and to problems of diagenesis of clastic sediments. In: Stable Isotopes in Sedmentary Geology. M.A. Arthur (ed.). SEPM Shourt Course Notes 10, p. 4-1 - 4-22.

Legall, F.D., Barnes, C.D., and Macqueen, R.W. 1981. Thermal maturation, burial history and hotspots development Paleozoic strata of southern Ontario-Quebec, from conodont and acritarch colour alteration studies. Canadian Petroleum Geology, Bulletin, v. 29, p. 492-539.

Lumbers, S.B. 1980. Geology of Renfrew County, Southern Ontario. Ontario Geological Survey, Open File Report 5282, 1 table, p. 118. 4 figures, and 4 maps (with 4 overlays), scale 1:31680.

Lumbers, S.B. and Vertolli, V.M. 1980. Geological series, Renfrew area, eastern part, southern Ontario. Ontario Geological Survey, Preliminary Map P.1838, scale 1:63 360. 
Machel, H.G. and Lonee, J. 2002. Hydrothermal dolomite - A product of poor definition and imagination. Sedimentary Geology, v. 152, p. 163-171.

McArthur, J.M., Howarth, R.J., and Bailey, T.R. 2001. Strontium Isotope Stratigraphy: LOWESS Version 3: Best Fit to the Marine Sr-Isotope Curve for 0-509 Ma and Accompanying Look-up Table for Deriving Numerical Age. The Journal of Geology, V. 109 , p. $155-170$.

McLennan, S. M. 1989. Rare earth elements in sedimentary rocks: influence of the provenance and sedimentary process.Geochemistry and Mineralogy of Rare Earth Elements, v. 21, p. 169-200

Mereu, R.F., Wang, D. Kuhn, O. Forsyth, D.A., Green, A.G., Morel, P., Buchbinder, G.G.R., Crossley, D. Schwarz, E. duBerger, R. Brooks, C. Clowes, R. 1986. The 1982 COCRUST seismic experiment across the Ottawa-Bonnechere graben and Grenville Front in Ontario and Quebec. Geophysical Journal of the Royal Astronomical Society, v. 84, p. 491-514.

Murthy, G.S. 1971. The paleomagnetism of diabase dikes from the Grenville Province. Canadian Journal of Earth Sciences, v. 8, p. 802-812.

Rankin, D.W., 1976. Appalachian salients and recesses: late Precambrian continental break up and the opening of the Iapetus Ocean. Journal of Geophysical Research, v. 81, p. $5605-5619$.

Rimando, R.E. and Benn, K. 2005. Evolution of faulting and paleo-stress field within the Ottawa graben, Canada. Journal of Geodynamics, v. 39, p. 337-360. 
Rocher, M. Tremblay, A. Lavoie, D. And Campeau, A. 2003. Brittle fault evolution of the Montreal area (St. Lawrence Lowlands, Canada): Rift-related structural inheritance and tectonism approached by paleostress analysis. Geological Magazine, v. 140, p. $157-172$.

Roedder, E. 1963. Studies offluid inclusions II. Freezing data and their interpretation. Economic Geology, v. 58, p. 167-211.

Salad Hersi, O. and Dix, G.R. 1999. Blackriveran (lower Mohawkian, upper Ordovician) lithostratigraphy, rhythmicity, and paleogeography: Ottawa Embayment, eastern Ontario Canada. Canadian Journal of Earth Sciences, v.36, p. 2033-2050.

Salad Hersi, O. and Dix, R.G. 1997. Hog's Back Formation: A New Lithostratigraphic Unit in the Middle Ordovician of the Ottawa Embayment, Eastern Ontario, Canada. Canadian Journal of Earth Sciences, v. 34, p. 588-597.

Sanford, B.V. 1993. St. Lawrence Platform-Geology. In: Sedimentary cover of the craton in Canada. D.F. Stott and J.D. Aitken, (eds.). Geological Survey of Canada, No. 5, p. 723-786.

Sanford, B.V. 1993a. St. Lawerence Platform - introduction. In: Sedimentary Cover of the Craton in Canada. D.F. Scott and J.D. Aitken (eds.). Geological Survey of Canada, Geology of Canada 5, p. 709-722. (also DNAG vol. D-1).

Sanford, B.V. and Arnott, R.W.C. 2010. Stratigraphic and structural framework of the Potsdam Group in eastern Ontario, western Quebec, and northern New York State. Geological Survey of Canada, Bulletin, v. 597, p. 83. 
Sengor, A.M.C., Burke, K. Dewey, J.F. 1978. Rifts at high angles to orogenic belts: tests for their origin and the Upper Rhine Graben as an example. American Journal of Science, v. 278, p. 24-40.

Sharma, S. and Dix, G.R. 2004. Magnesian calcite and chamositic ooids forming shoals peripheral to Late Ordovician (Ashgill) muddy siliciclastic shores: southern Ontario. Palaeogeography, Palaeoclimatology, Palaeoecology. Elsevier. v. 210, p. 349-368.

Sharma, S. Dix, G.R., and Riva, J.F.V. 2003. Late Ordovician platform foundering, its paleoceanography and burial, as preserved in separate (eastern Michigan Basin, Ottawa Embayment) basins, southern Ontario. Canadian Journal of Earth Sciences, v. 40, p. $135-148$.

Shields, G.A. and Webb, G.E. 2004. Has the REE composition of seawater changed over geological time? Chemical Geology, v. 204, p. 103-107.

Shields, G.A., Carden, G.A.F., Veizer, J. Meidla, T. Rong, J.-Y. and Li, R.-Y. 2003. Sr, C and $\mathrm{O}$ isotope geochemistry of Ordovician brachiopods: a major event around the Middle-Late Ordovician transition. Geochimica et Cosmochimica Acta (4.2), v. 67, p. 2005-2025.

Sibley, D.F. and Gregg, J. M. 1987. Classification of Dolomite Rock Textures. Journal of Sedimentary Petrology, v. 57, p. 967-975.

Sloss, L.L. 1963. Sequences in the cratonic interior of North America: Geological Society of America, Bulletin, v. 74, p. 93-113. 
Sloss, L.L. 1988. Tectonic evolution of the craton in Phanerozoic time. In: Sedimentary Cover - North America Cration. L.L. Sloss (ed.). Geological Society of America, Boulder, Colorado, Geology of North America, v. D-2, p. 25-51.

Smith, L. B. Jr., 2006, Origin and reservoir characteristics of Upper Ordovician TrentonBlack River hydrothermal dolomite reservoirs in New York. American Association of Petroleum Geologists, Bulletin, v. 90, p. 1691- 1718.

Spencer, R. J. 1987. Origin of Ca-Cl brines in Devonian formations, Western Canada sedimentary basin. Applied Geochemistry, v. 2, p. 373-384.

Steele-Petrovich, H.M. 1984. Stratigraphy and paleoenvironments of Middle Ordovician carbonate rocks, Ottawa Valley, Canada. Ph.D. Thesis, Yale University, New Haven, Connecticut.

Swezey C.S. 2008. Regional stratigraphy and petroleum systems of the Michigan basin, North America: U.S. Geological Survey Scientific Investigations Map 2978 (one oversized chart).

Taylor, S. R. and McLennan, S. M. 1985. The Continental Crust: Its Composition and Evolution. Oxford (Blackwell Scientific).

Tremblay, A. Long, B. and Massé, M. 2003. Supracrustal faults of the St. Lawrence rift system, Québec: Kinematics and geometry as revealed by field mapping and marine seismic reflection data. Tectonophysics, v. 369, p. 231-252.

Tucker, M. E. and Wright, V.P. 1990. Carbonate Sedimentology: Oxford, Blackwell Scientific Publications, p. 496. 
Uyeno, T.T. 1974. Conodonts of the Hull Formation, Ottawa Group (Middle Ordovician), of the Ottawa-Hull area, Ontario and Quebec. Geological Survey of Canada, Bulletin, v. 248 , p. $1-31$.

Vasconcelos, C. McKenzie, J. A., Warthmann, R. and Bernasconi, S. M. 2005.

Calibration of the $\delta^{18} \mathrm{O}$ paleothermometer for dolomite precipitated in microbial cultures and natural environments. Geology, v. 33, p. 317-320.

Veizer, J. and Compston, W. 1976. Sr-87-Sr-86 in Precambrian Carbonates as an Index of Crustal Evolution. Geochimica et Cosmochimica Acta (40), v. 8, p. 905-914.

Warren, J. 1999. Evaporites. Their Evolution and Economics, p. 1-438.

Water well geology (formation tapped by drilling): WWIS database

(http://www.ene.gov.on.ca) regional faults: Pembroke East (eastern part): Preliminary Map P.2356 1 sheet, 1:63630

White, D. E. 1957. Thermal waters of volcanic origin. Geological Society of America, Bulletin, v. 68, p. $1637-1658$.

Wilcox, R. E., Harding, T. P. and Seely, D. R. 1973. Basic wrench tectonics. American Association of Petroleum Geologists, Bulletin, v. 57, p. 74-96.

Williams, D.A. 1991. Paleozoic geology of Ottawa - St. Lawrence Lowlands, southern Ontario. Ontario Geological Survey, Open File Report 5770.

Wilson, T.P. and Long, D.T. 1992. Geochemistry and isotope chemistry of Michigan Basin brines: Devonian formations. Applied Geochemistry, v. 8, p. 81-100. 


\section{APPENDICES}

Appendix I. Geochemical data

Table 1. Fluid inclusion analysis data

\begin{tabular}{|c|c|c|c|c|c|c|}
\hline & Sample & Chip & $\begin{array}{c}\text { fluid } \\
\text { inclusion } \\
\text { № } \\
\end{array}$ & Type* & Nature & Th ${ }^{0} \mathrm{C}$ \\
\hline \multirow[t]{20}{*}{ Locality 1} & $7-1$ & L2-F2 & 1 & primary/ps & calcite & 60 \\
\hline & $7-1$ & L2-F2 & 2 & primary/ps & calcite & 60 \\
\hline & $7-1$ & L2-F2 & 3 & primary/ps & calcite & 85 \\
\hline & $7-1$ & L2-F2 & 4 & primary/ps & calcite & 85 \\
\hline & $7-1$ & L2-F2 & 5 & primary/ps & calcite & 85 \\
\hline & $7-1$ & L2-F2 & 6 & primary/ps & calcite & 85 \\
\hline & $7-1$ & L4 & 1 & primary/ps & calcite & 120 \\
\hline & $7-1$ & L4 & 2 & primary/ps & calcite & 120 \\
\hline & $10-1$ & $\mathrm{~L} 1-\mathrm{F} 1$ & 1 & primary & saddle dolomite & 87.2 \\
\hline & $10-1$ & L1-F2 & 1 & primary & saddle dolomite & 102 \\
\hline & $10-1$ & L1-SFI & 1 & secondary & saddle dolomite & 96.8 \\
\hline & $10-1$ & L1-SFI & 2 & secondary & saddle dolomite & 92.8 \\
\hline & $10-1$ & L1-SFI & 3 & secondary & saddle dolomite & 96.1 \\
\hline & $10-1$ & L1-SFI & 4 & secondary & saddle dolomite & 98.2 \\
\hline & $10-1$ & L1-SFI & 5 & secondary & saddle dolomite & 108.5 \\
\hline & $23-1$ & $\mathrm{~L} 2$ & 1 & primary & saddle dolomite & 100 \\
\hline & $23-1$ & $\mathrm{~L} 1$ & 1 & primary & saddle dolomite & 115 \\
\hline & $\mathrm{x}$-breccia & $\mathrm{L} 1$ & 1 & primary/ps & saddle dolomite & 90 \\
\hline & x-vein & L2 & 1 & primary & saddle dolomite & 110 \\
\hline & $\mathrm{x}$-vein & L3 & 1 & primary & saddle dolomite & 107 \\
\hline \multirow[t]{9}{*}{ Locality 2} & $32-1$ & L2-F1 & 1 & primary/ps & calcite & 65 \\
\hline & $32-1$ & L2-F1 & 2 & primary/ps & calcite & 80 \\
\hline & $32-1$ & L2-F2 & 1 & primary/ps & calcite & 83.2 \\
\hline & $32-1$ & L2-F2 & 2 & primary/ps & calcite & 110 \\
\hline & $32-1$ & L3 & 1 & primary/ps & calcite & 85 \\
\hline & Bo-2-1 & L1-F1 & 1 & primary/ps & saddle dolomite & 95.2 \\
\hline & Bo-2-1 & L1-F2 & 1 & primary/ps & saddle dolomite & 105 \\
\hline & Bo-2-1 & L2 & 1 & primary/ps & saddle dolomite & 100 \\
\hline & Bo-2-1 & L3 & 1 & primary/ps & saddle dolomite & 102 \\
\hline
\end{tabular}

*classification of fluid inclusions based on Goldstein and Reynolds (1994) 


\begin{tabular}{|c|c|c|c|c|c|c|c|c|c|c|c|c|}
\hline$\forall \therefore$ & రా & ర0. & $\stackrel{\tilde{0}}{0}$ & ¿ே. & $\stackrel{5}{0}$ & $\stackrel{1}{0}$ & $\ddot{0}$ & $\begin{array}{l}\bar{O} \\
\dot{0} \\
v\end{array}$ & ọ & $\begin{array}{l}\tilde{O} \\
0 \\
\dot{0}\end{array}$ & $\hat{0}$ & ○! \\
\hline Ũ & $\stackrel{0}{2}$ & $\tilde{z}$ & ô & $\stackrel{0}{=}$ & $\vec{\infty}$ & $\stackrel{m}{\beth}$ & $\stackrel{n}{n}$ & 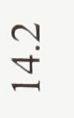 & $\stackrel{n}{n}$ & $\stackrel{ }{\Xi}$ & $\stackrel{2}{0}$ & $\stackrel{n}{\sim}$ \\
\hline 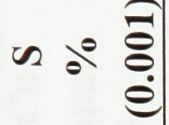 & $\stackrel{n}{0}$ & $\begin{array}{l}n \\
0 \\
0\end{array}$ & \begin{tabular}{l}
0 \\
\multirow{2}{0}{} \\
0
\end{tabular} & 三 & $\begin{array}{l}\hat{n} \\
0 \\
0\end{array}$ & $\begin{array}{l}\overparen{2} \\
0 \\
0\end{array}$ & 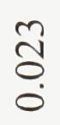 & $\begin{array}{l}1 \\
0 \\
0\end{array}$ & 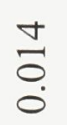 & $\begin{array}{l}0 \\
8 \\
0 \\
0\end{array}$ & $\begin{array}{l}\widehat{\widehat{\sigma}} \\
0 \\
0\end{array}$ & 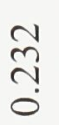 \\
\hline 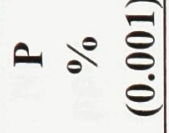 & $\begin{array}{l}0 \\
8 \\
0\end{array}$ & $\begin{array}{l}n \\
8 \\
0 \\
0\end{array}$ & $\begin{array}{l}\text { ก̊ } \\
\stackrel{0}{0}\end{array}$ & $\begin{array}{l}n \\
8 \\
0\end{array}$ & $\begin{array}{l}n \\
8 \\
0\end{array}$ & $\begin{array}{l}\overline{8} \\
\stackrel{0}{0}\end{array}$ & $\begin{array}{l}5 \\
8 \\
0\end{array}$ & $\begin{array}{l} \pm \\
0 \\
0\end{array}$ & $\begin{array}{l}\hat{n} \\
0 \\
0\end{array}$ & $\begin{array}{l}\tilde{O} \\
8 \\
0 \\
v\end{array}$ & $\begin{array}{l}\hat{\mho} \\
\stackrel{0}{0}\end{array}$ & $\begin{array}{l}\stackrel{8}{8} \\
\stackrel{0}{0}\end{array}$ \\
\hline Z & $\hat{0}$ & $\stackrel{m}{0}$ & $\stackrel{0}{0}$ & $\begin{array}{l}\text { Iै } \\
0\end{array}$ & $\hat{0}$ & \begin{tabular}{l}
\multirow{O}{0}{} \\
0
\end{tabular} & 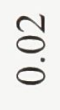 & $\begin{array}{l}\tilde{0} \\
\dot{0} \\
v\end{array}$ & $\begin{array}{l}\text { Oै } \\
\stackrel{0}{0}\end{array}$ & $\begin{array}{l}0 \\
0 \\
0 \\
v\end{array}$ & @्रे & $\stackrel{\infty}{\circ}$ \\
\hline$\sum^{\infty} \circ \stackrel{\theta}{\hat{\theta}}$ & 巳্ঠ & $\hat{n}$ & $\begin{array}{l}\overrightarrow{6} \\
\dot{n}\end{array}$ & ֻै & $n$ & ạ & $\frac{2}{\infty}$ & $\ddot{0}$ & $\stackrel{0}{\circ}$ & 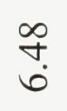 & $\stackrel{n}{0}$ & $\frac{7}{0}$ \\
\hline$\tilde{z}$ ¿ & $\frac{0}{0}$ & 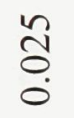 & $\frac{1}{0}$ & \begin{tabular}{l}
0 \\
\multirow{0}{0}{} \\
0
\end{tabular} & $\hat{0}$ & $\begin{array}{l}\hat{n} \\
0 \\
0\end{array}$ & ก̂. & $\begin{array}{l}\frac{9}{0} \\
0 \\
0\end{array}$ & $\stackrel{n}{n}$ & $\begin{array}{l}\text { ป̂ } \\
0 \\
0\end{array}$ & ڤై & $\begin{array}{l}\mathscr{m} \\
0 \\
0\end{array}$ \\
\hline$\bullet \stackrel{\Xi}{2} \Xi$ & 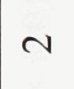 & 6 & $\nabla$ & $m$ & $m$ & $n$ & $n$ & $\sim$ & $\nabla$ & $\forall$ & $N$ & $\nabla$ \\
\hline 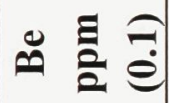 & $\overrightarrow{0}$ & $\vec{o}$ & $\vec{o}$ & $\vec{o}$ & $\overrightarrow{0}$ & $\begin{array}{l}\overrightarrow{0} \\
V\end{array}$ & $\vec{o}$ & $\begin{array}{l}ت \\
\dot{0}\end{array}$ & $\vec{o}$ & $\vec{o}$ & $\ddot{0}$ & $\begin{array}{l}\overrightarrow{0} \\
V\end{array}$ \\
\hline 凹泀 & $\stackrel{+}{0}$ & ñ & $n$ & ? & $\stackrel{+}{\circ}$ & $n$ & ?’ & ֻ̃ & $\stackrel{N}{0}$ & $\ddot{0}$ & $n$ & $\stackrel{6}{-}$ \\
\hline$\underset{\mathrm{E}}{\stackrel{D}{E}}$ & 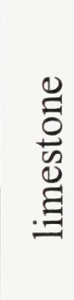 & $\begin{array}{l}\stackrel{0}{0} \\
\frac{0}{0} \\
\frac{0}{0}\end{array}$ & $\begin{array}{l}0 \\
\frac{0}{00} \\
\frac{0}{0} \\
0\end{array}$ & $\begin{array}{l}0 \\
0 \\
0 \\
0 \\
\frac{0}{0} \\
0\end{array}$ & $\begin{array}{l}\frac{0}{0} \\
\frac{0}{0} \\
\frac{0}{0} \\
\frac{0}{0}\end{array}$ & $\begin{array}{l}\frac{0}{0} \\
\frac{0}{0} \\
\frac{0}{0} \\
\frac{0}{0}\end{array}$ & $\begin{array}{l}\frac{0}{0} \\
\frac{0}{0} \\
\frac{0}{0} \\
\frac{0}{0}\end{array}$ & 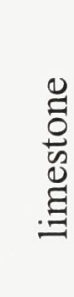 & $\begin{array}{l}0 \\
\tilde{0} \\
0 \\
0 \\
0 \\
0\end{array}$ & 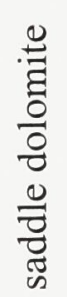 & 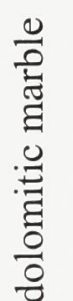 & 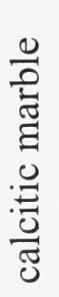 \\
\hline 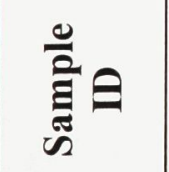 & $\frac{a}{n}$ & $\begin{array}{l}\frac{1}{6} \\
\text { T1 } \\
\text { r }\end{array}$ & ค่ & $\begin{array}{l}\text { U } \\
\text { i } \\
i\end{array}$ & อ̆ & $\stackrel{p}{1}$ & $\begin{array}{l}Z \\
\stackrel{1}{1}\end{array}$ & $\begin{array}{l}-1 \\
\vdots \\
0 \\
\frac{1}{1} \\
\alpha\end{array}$ & 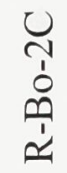 & $\frac{b}{a}$ & 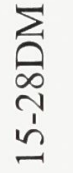 & $\underset{\substack{n \\
n}}{i}$ \\
\hline & & & 苞 & & & & & & 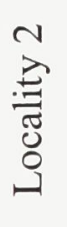 & & & \\
\hline
\end{tabular}




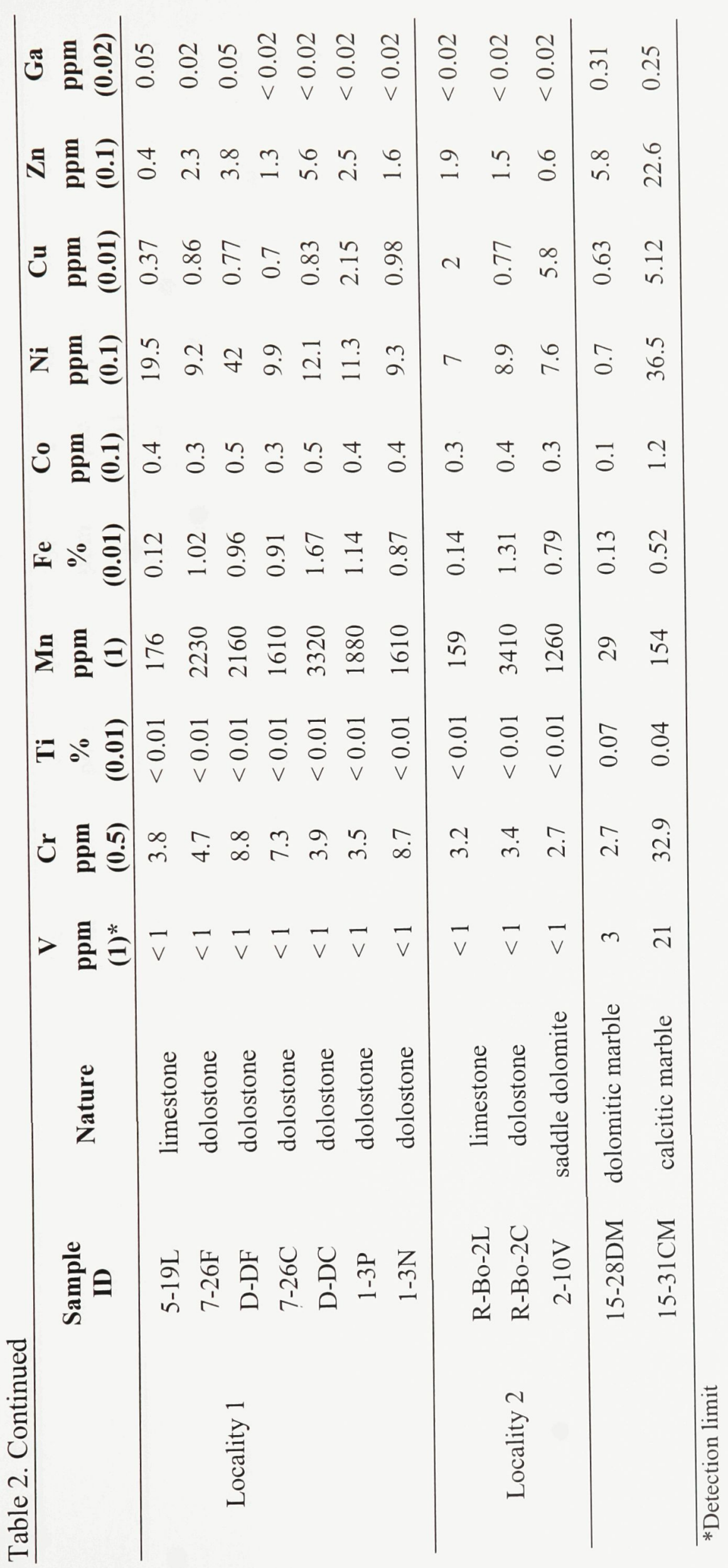




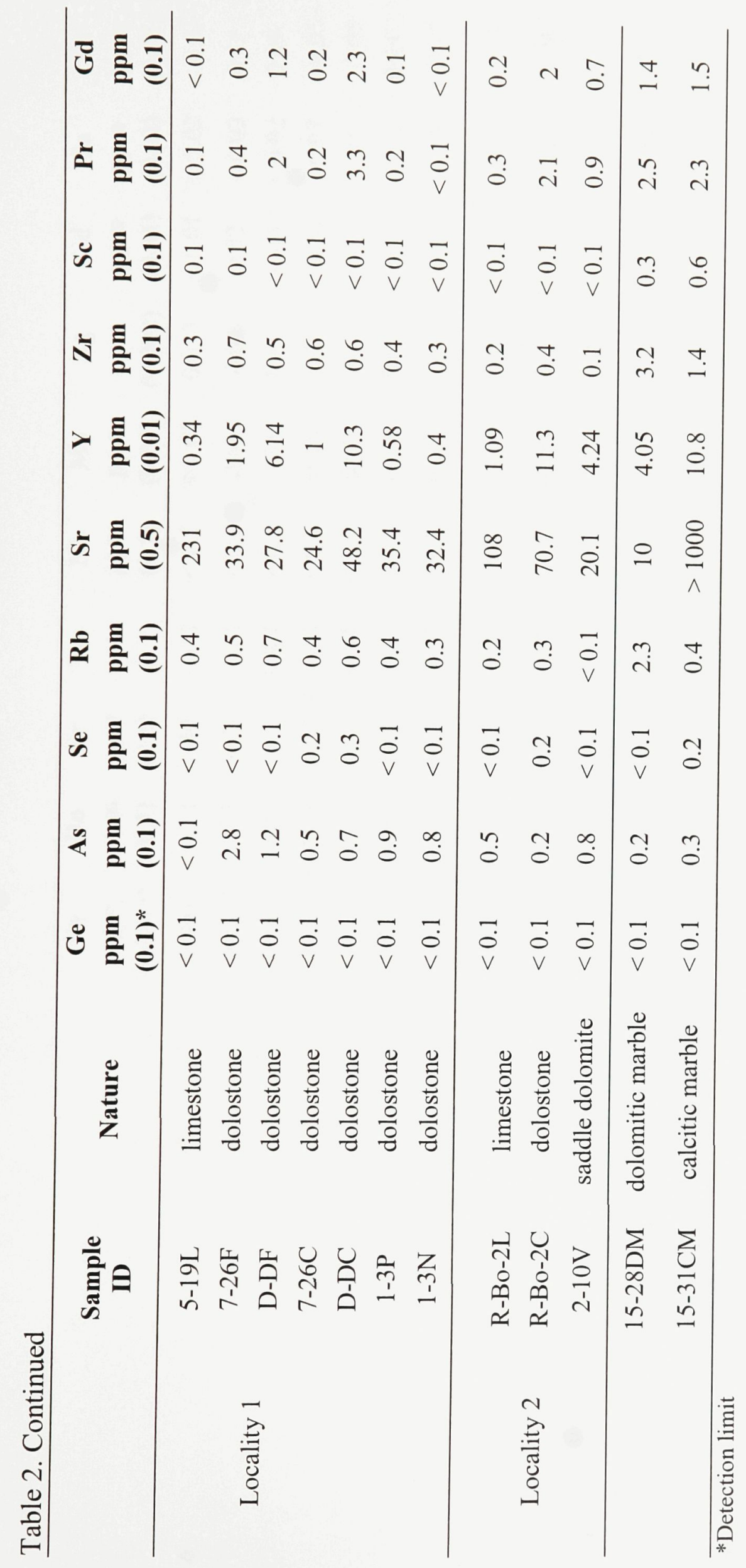




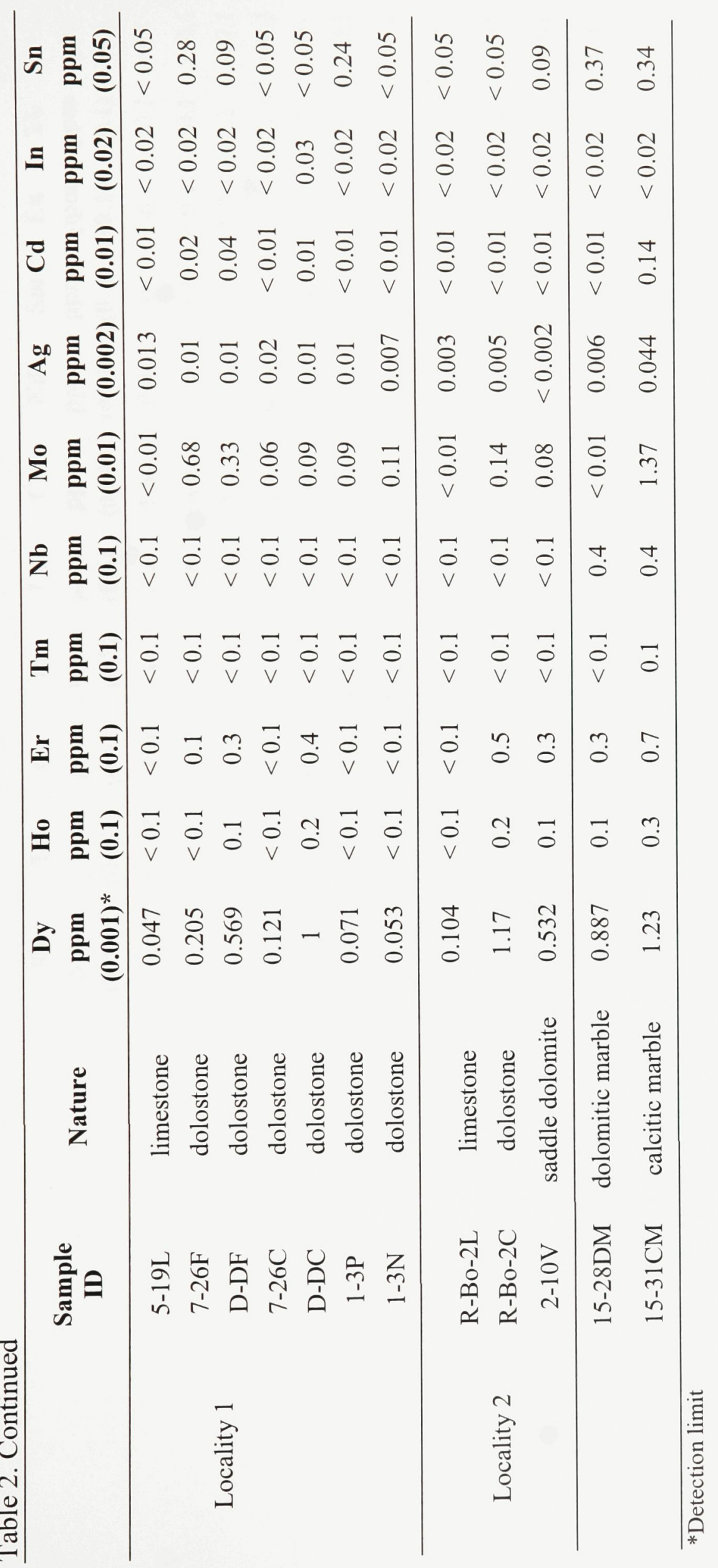




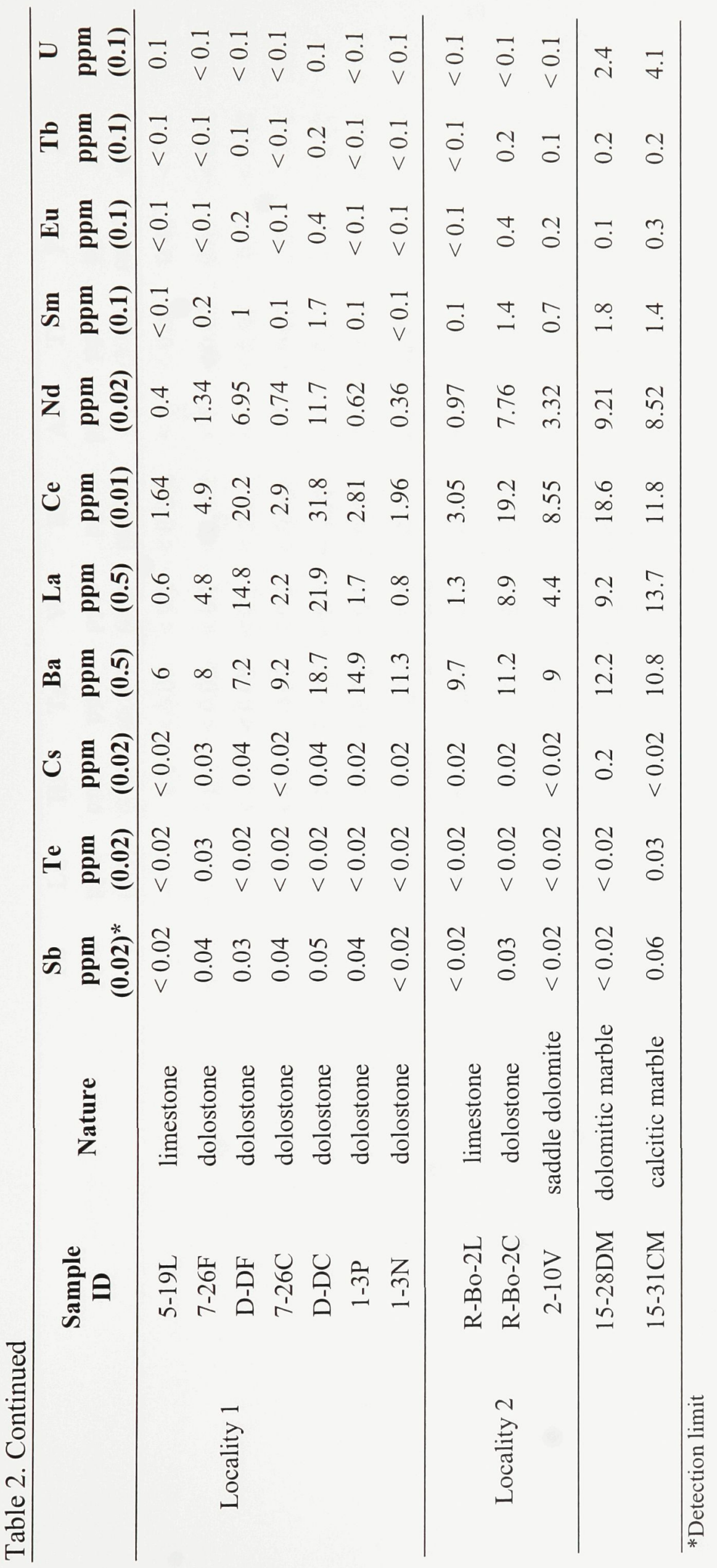




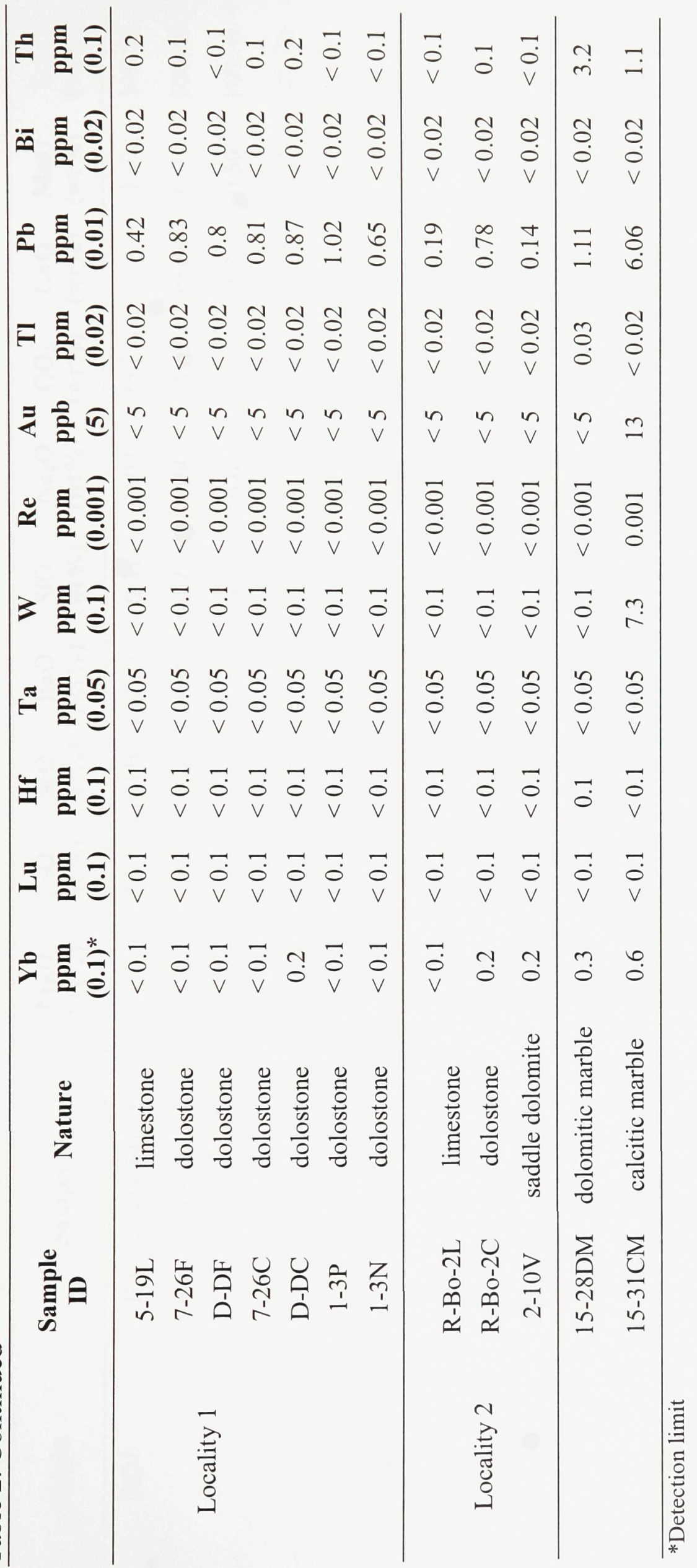




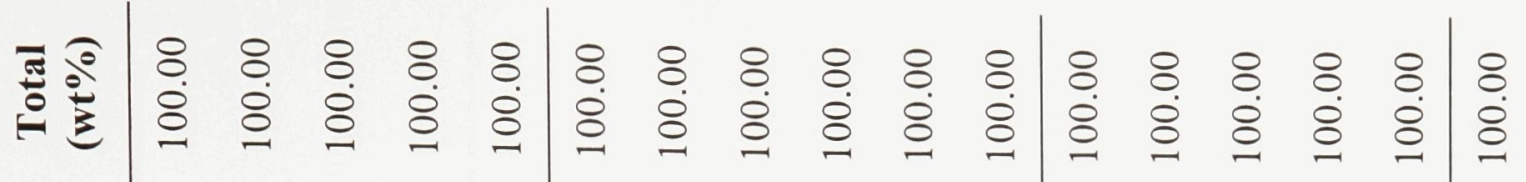

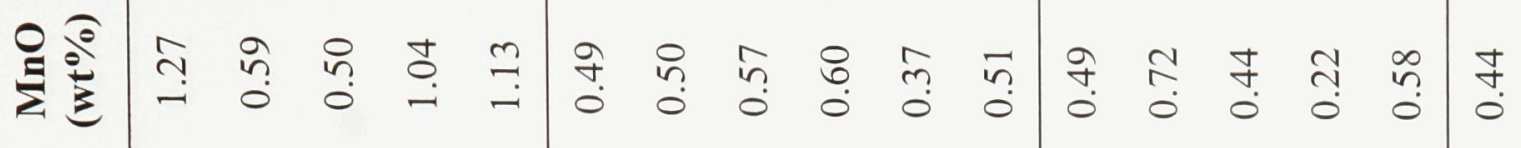

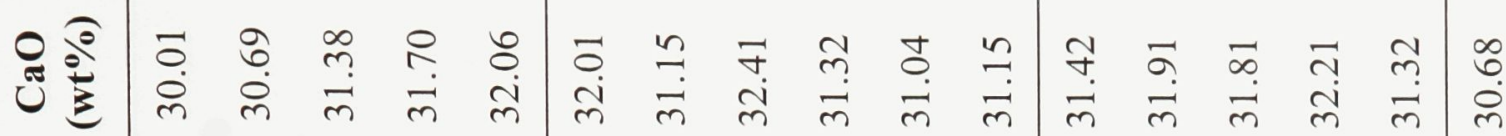

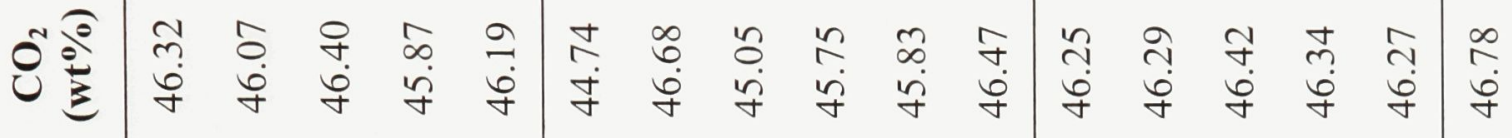

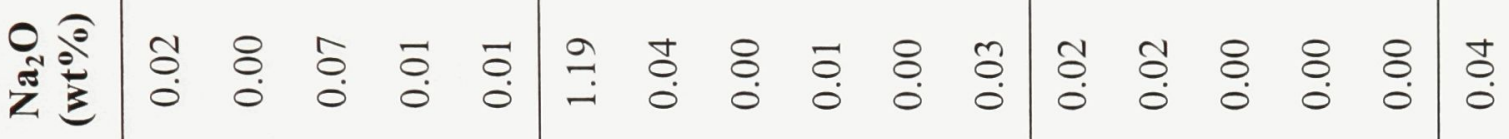
की 离章

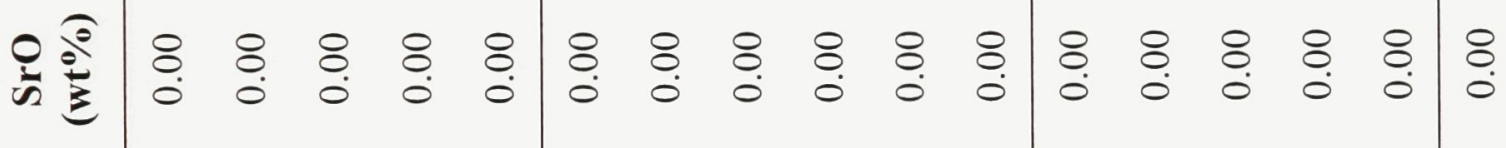

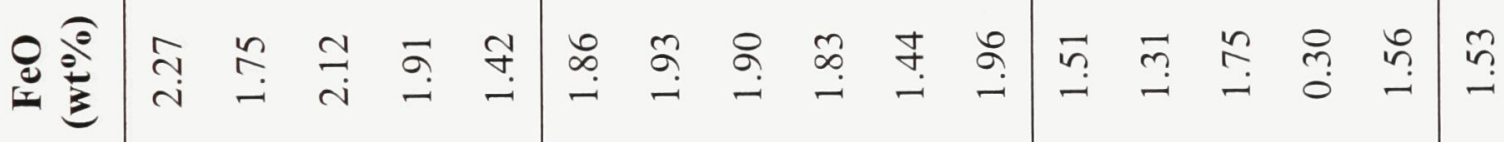

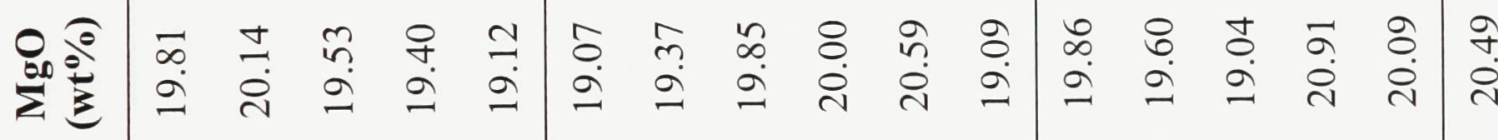




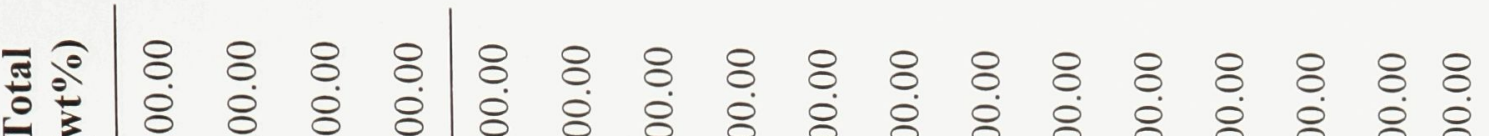

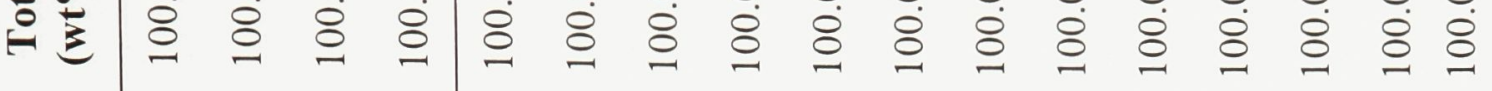

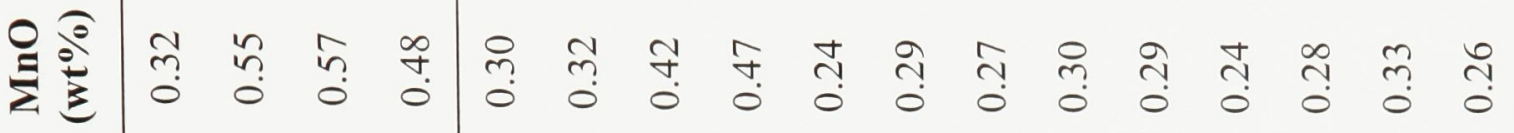

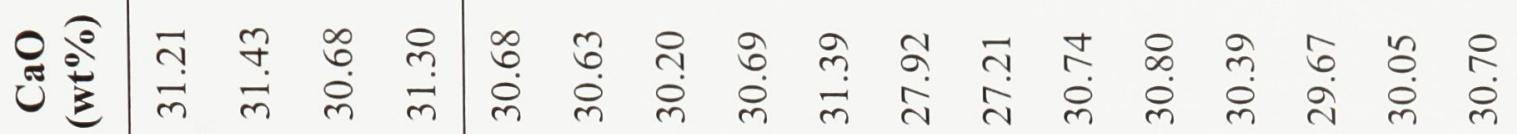
ঠூ 䒕

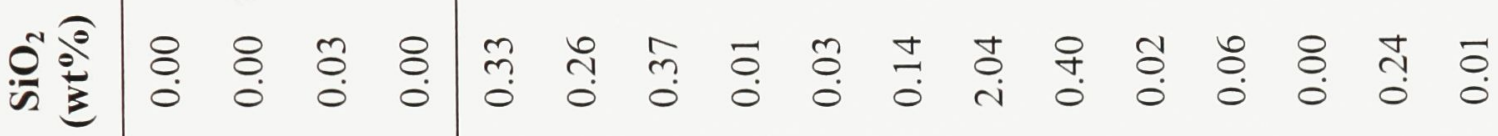
苞 뉸 距 일 $\cong$ n 选 
స๐

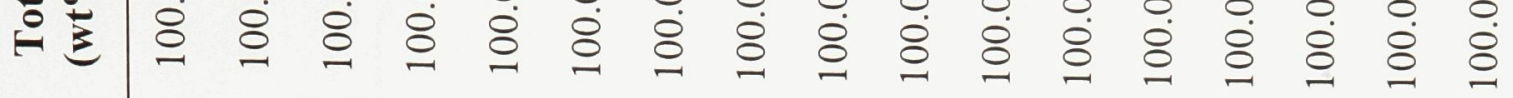
至 U

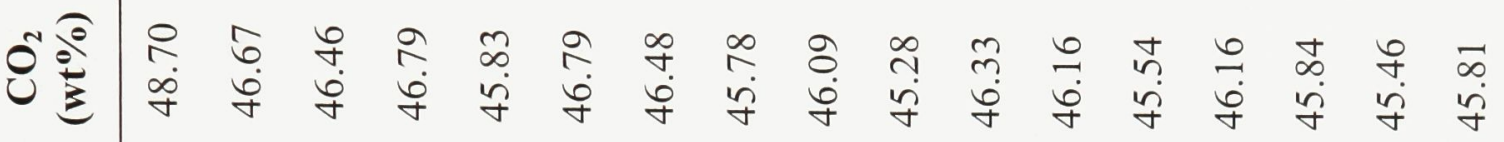
そ) 嗂 랩 낸 垂

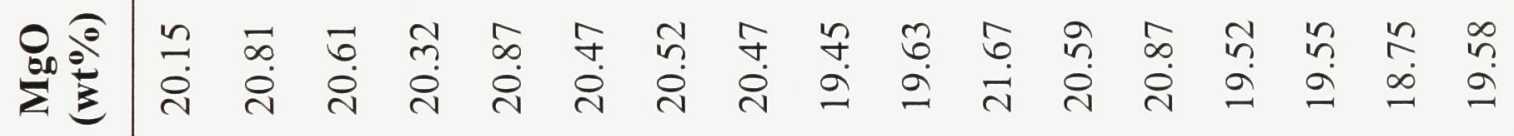




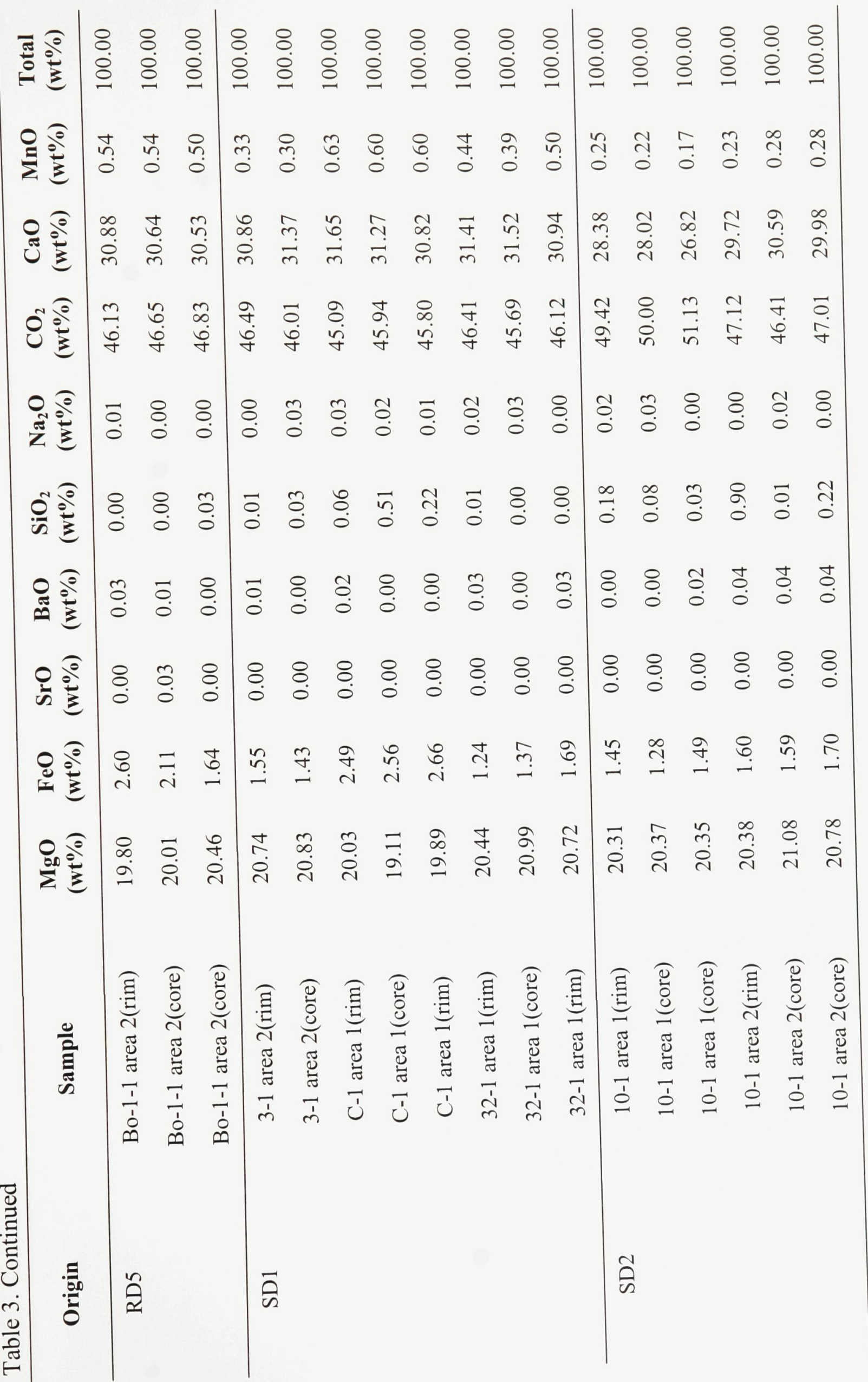




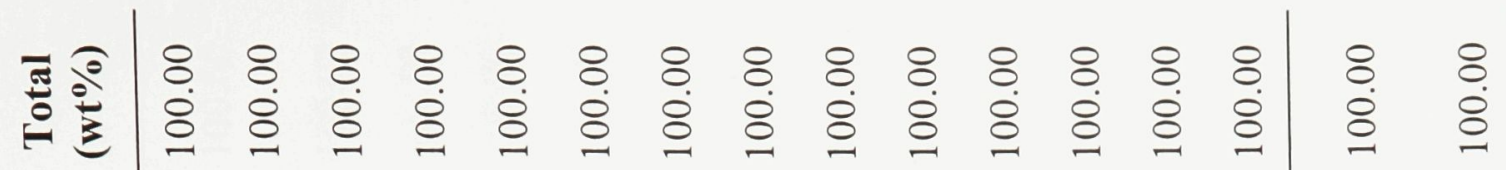

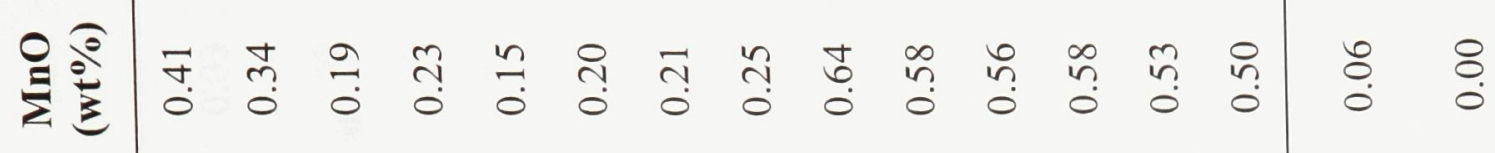

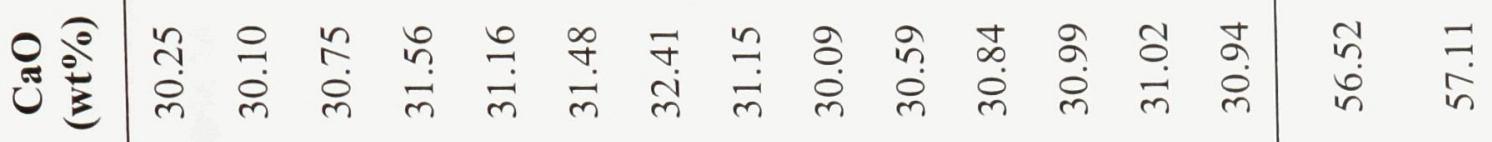

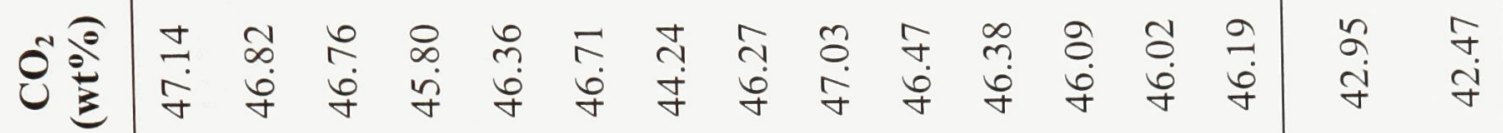
艺 年

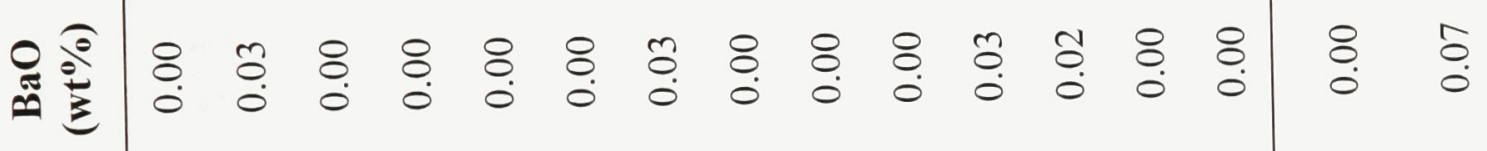
낸

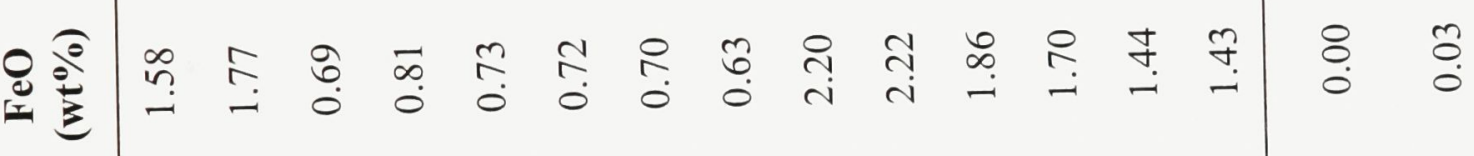

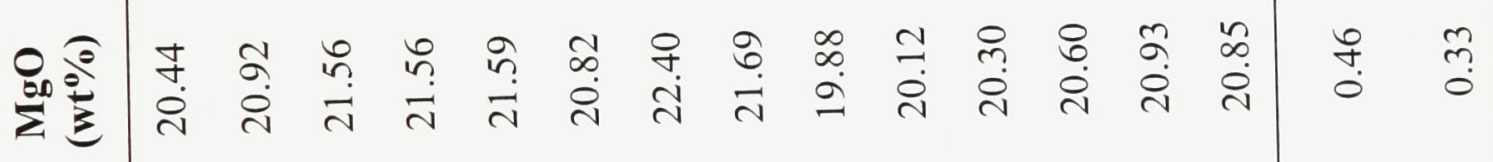


입

严

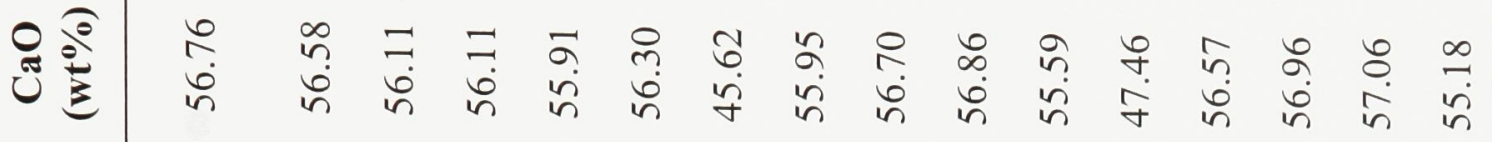
ঠூฮ

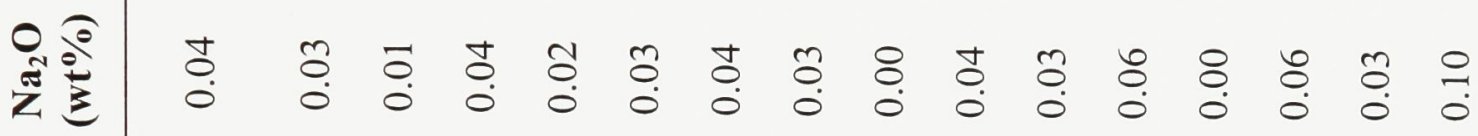

诲

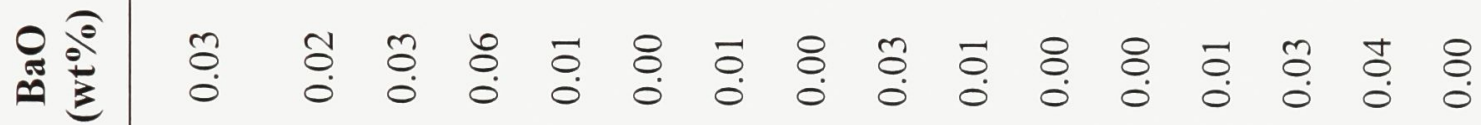

吕

尊

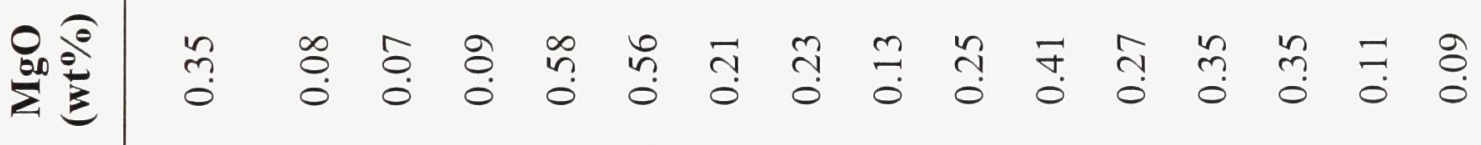

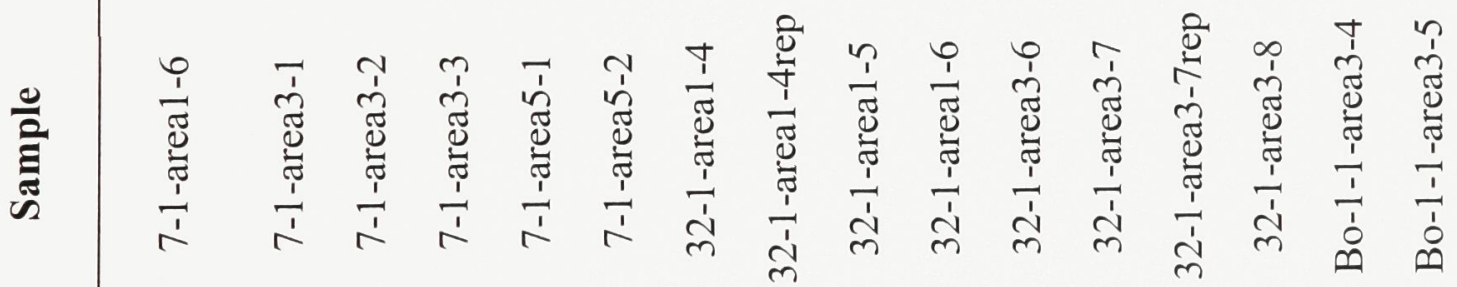

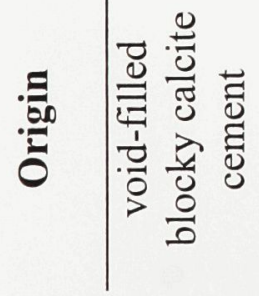




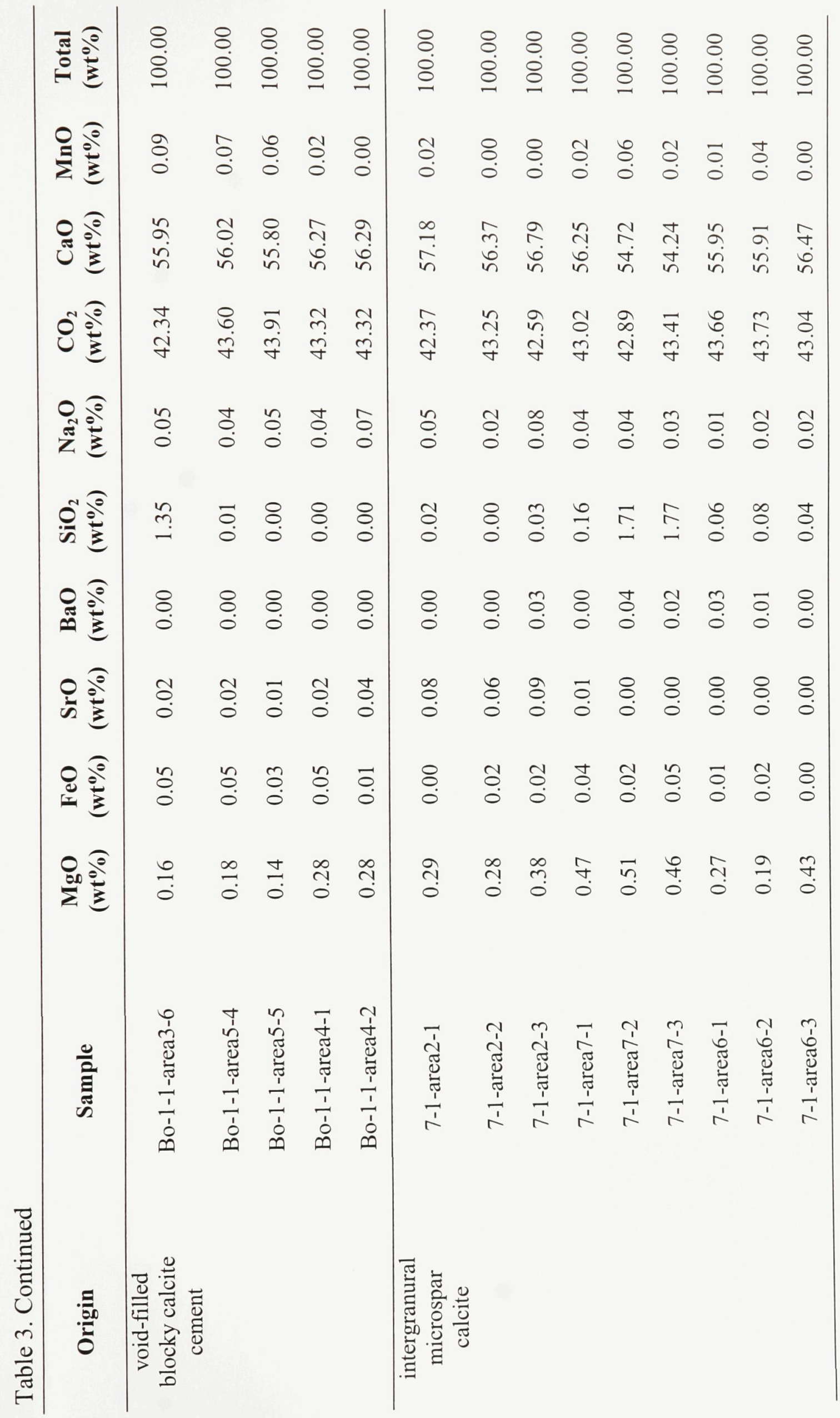




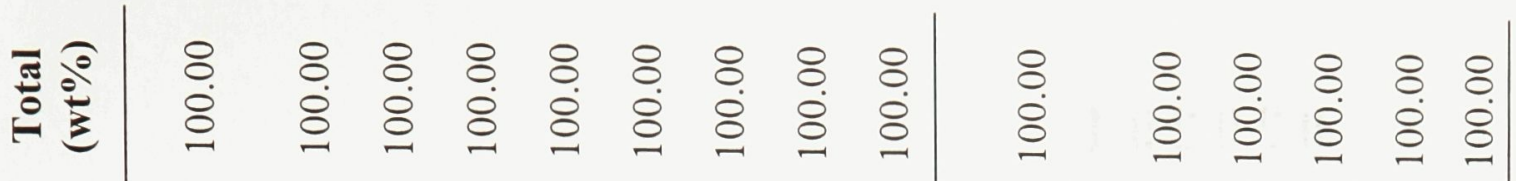

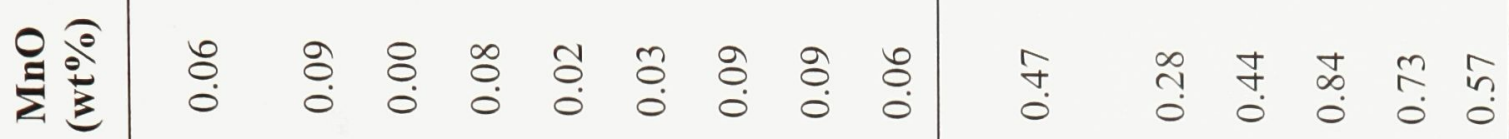

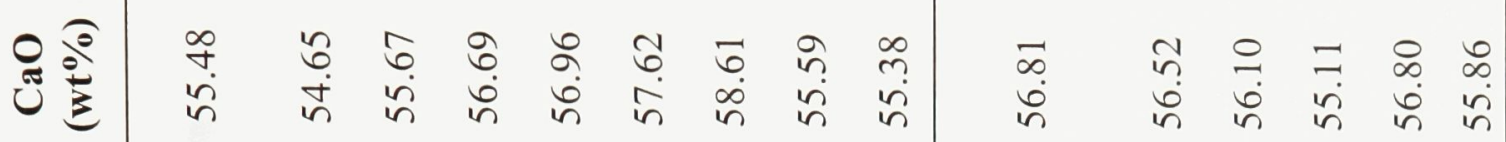
ঠூ 彳 向 点 请 荥

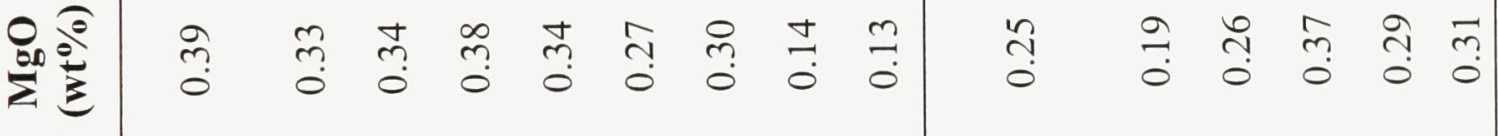

